Issued by Sandia National Laboratories, operated for the United States

Department of Energy by Sandia Corporation.

NOTICE: This report was prepared as an account of work sponsored by an agency of the United States Government. Neither the United States Government, nor any agency thereof, nor any of their employees, nor any of their contractors, subcontractors, or their employees, make any warranty, express or implied, or assume any legal liability or responsibility for the accuracy, completeness, or usefulness of any information, apparatus, product, or process disclosed, or represent that its use would not infringe privately owned rights. Reference herein to any specific commercial product, process, or service by trade name, trademark, manufacturer, or otherwise, does not necessarily constitute or imply its endorsement, recommendation, or favoring by the United States Government, any agency thereof, or any of their contractors or subcontractors. The views and opinions expressed herein do not necessarily state or reflect those of the United States Government, any agency thereof, or any of their contractors.

Printed in the United States of America. This report has been reproduced directly from the best available copy.

Available to DOE and DOE contractors from

U.S. Department of Energy

Office of Scientific and Technical Information

P.O. Box 62

Oak Ridge, TN 37831

Telephone: (865)576-8401

Facsimile: (865)576-5728

E-Mail: reports@adonis.osti.gov

Online ordering: http://www.doe.gov/bridge

Available to the public from

U.S. Department of Commerce

National Technical Information Service

5285 Port Royal Rd

Springfield, VA 22161

Telephone: (800)553-6847

Facsimile: (703)605-6900

E-Mail: orders@ntis.fedworld.gov

Online order: http://www.ntis.gov/ordering.htm

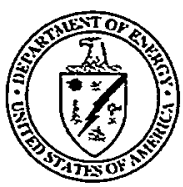




\section{DISCLAIMER}

Portions of this document may be illegible in electronic image products. Images are produced from the best available original document. 
SAND2000-2702

Unlimited Release

Printed November 2000

AECENVED

NOV 242000

OSTI

\author{
ADVANCED SUBSURFACE CONTAINMENT SYSTEMS \\ DESIGN AND PERFORMANCE EVALUATION OF REACTIVE MEDIA \\ TECHNICAL TASK PLAN NO. AL-28-SS-40
}

\title{
DESIGN, CONSTRUCTION AND MONITORING OF A PERMEABLE REACTIVE BARRIER TECHNOLOGY FOR USE AT ROCKY FLATS ENVIRONMENTAL TECHONOLOGY SITE (RFETS)
}

\author{
Brian P. Dwyer \\ Environmental Restoration Technologies Department \\ Sandia National Laboratories \\ P.O. Box 5800 \\ Albuquerque, NM 87185-0719
}

\begin{abstract}
Three reactive materials were evaluated at laboratory scale to identify the optimum treatment reagent for use in a Permeable Reactive Barrier (PRB) Treatment System at Rocky Flats Environmental Technology Site (RFETS). The contaminants of concern (COCs) are uranium, TCE, PCE, carbon tetrachloride, americium, and vinyl chloride. The three reactive media evaluated included high carbon steel iron filings, an iron-silica alloy in the form of a foam aggregate, and a pellicular humic acid based sorbant mixed with sand. Each material was tested in the laboratory at column scale using simulated site water. All three materials showed promise for the 903 Mound Site; however, the iron filings were determined to be the least expensive media. In order to validate the laboratory results, the iron filings were further tested at a pilot scale (field columns) using actual site water. Pilot test results were similar to laboratory results; consequently, the iron filings were chosen for the full-scale demonstration of this reactive barrier technology. Additional design parameters including saturated hydraulic conductivity, treatment residence time, and head loss across the media were also determined and provided to the design team in support of the final design. The final design was completed by the Corps of Engineers in 1997 and the system was constructed in the summer of 1998 with IT Corporation as the prime contractor. The design team included personnel from the Corps of Engineers, Sandia National Laboratories, RFETS, EnviroMetal Technology, Inc. (ETD), the US EPA, and MSE.
\end{abstract}

The new passive system was designed to replace the current active treatment method of collecting the contaminated groundwater at a seep, and transporting it periodically to an on-site treatment facility. The PRB was designed to intercept groundwater flow from the 903 Mound Site Plume at the most narrow down-gradient location and direct it into the treatment media. The design flow rate ranged from 0.1 to 2 gpm. The PRB is composed of a relatively impermeable HDPE vertical wall approximately $230 \mathrm{ft}$. in length and $17 \mathrm{ft}$. deep keyed into the underlying clay aquitard directing the contaminated groundwater into the treatment system. The treatment system began full operation in December, 1998 and despite a 
few problems has been operational since. Results to date are consistent with the lab and pilot scale findings, i.e., complete removal of the contaminants of concern (COCs) prior to discharge to meet RFCA (Rocky Flats Cleanup Agreement) requirements. Furthermore, it is fair to say at this point in time that laboratory developed design parameters for the reactive barrier technology are sufficient for full scale design; however, the treatment system longevity and the long-term fate of the contaminants are questions that remain unanswered. This project along with others PRBs such as the Durango, CO and Monticello, UT reactive barriers will provide the data to determine the long-term effectiveness and return on investment (ROI) for this technology for comparison to the baseline 'pump and treat'. 


\section{CONTENTS}

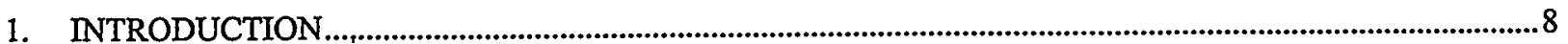

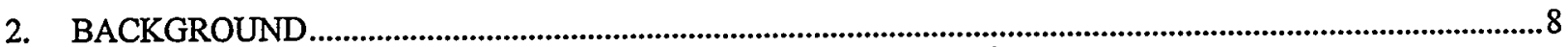

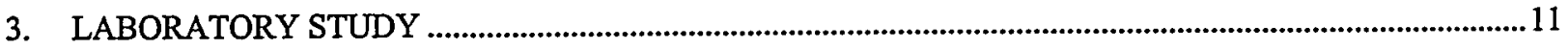

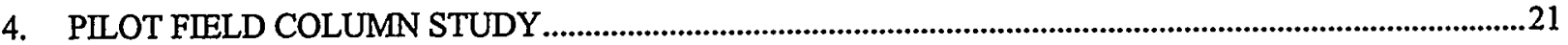

5. Full Scale reactive Barrier Design And Construction .............................................................................................25

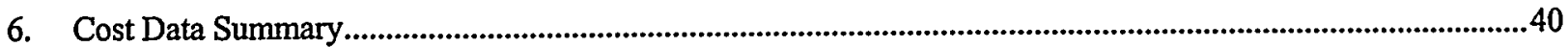

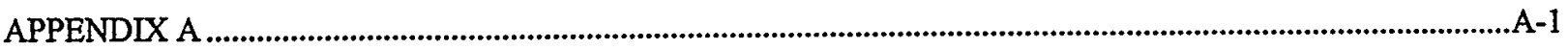

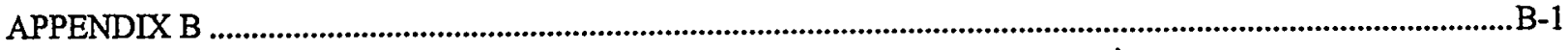

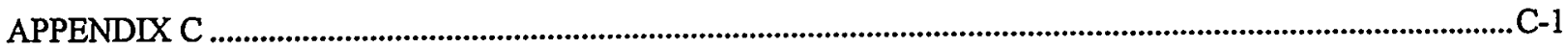

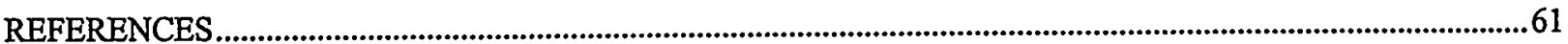

\section{FIGURES}

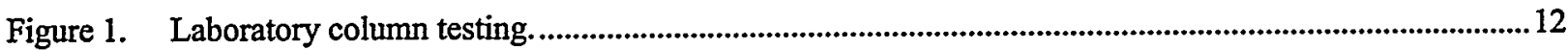

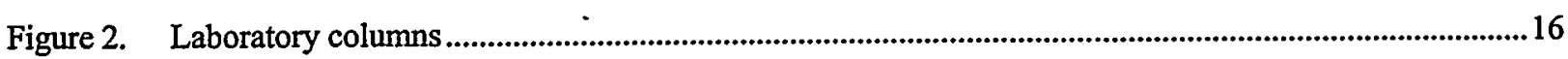

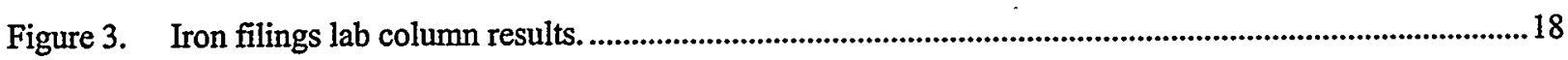

Figure 4. Iron foam lab column results. ............................................................................................................18

Figure 5. Humasorb lab column results. ............................................................................................................19

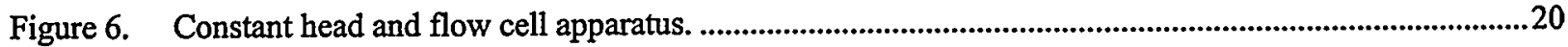

Figure 7. Pilot-scale field columns at rfets 903 mound site. ....................................................................................22

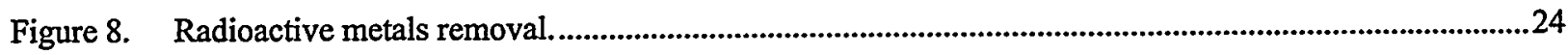

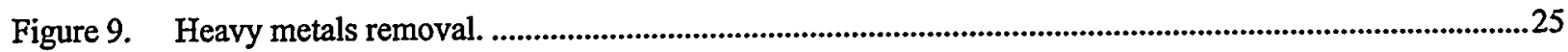

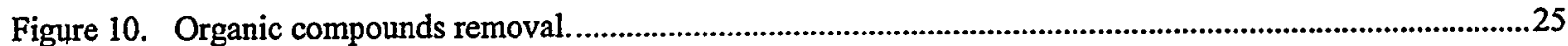

Figure 11. Schematic plan view of 903 mound site reactive barrier layout. .............................................................27

Figure 12. Schematic profile view of 903 mound site reactive barrier treatment system........................................28

Figure 13. Plan view of 903 mound site. Early stages of grading.................................................................................29

Figure 14. Installation of HDPE impermeable wall sections. Wall is composed of 10 wide interlocking panels with a hydrophilic seal in the joints........................................................................................................................31

Figure 15. HDPE collection wall and sump. Low cohesion (sloughing) soil conditions resulted in slanted installation of the hdpe in some areas of the wall.......................................................................................31

Figure 16. HDPE reactor vessels. Dimensions are $11^{\prime}-6$ " tall $\mathrm{x}$ 9'-10" in diameter.............................................32 
Figure 17. Reactor vessel loading . .32

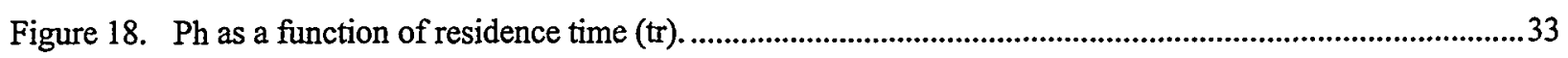

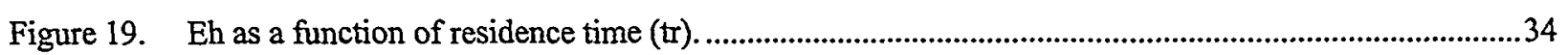

Figure 20. Dissolved oxygen (do) as a function of flowpath length.................................................................35

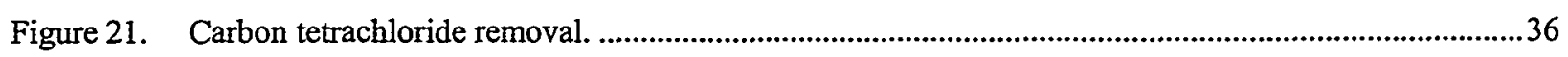

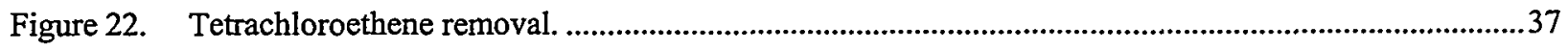

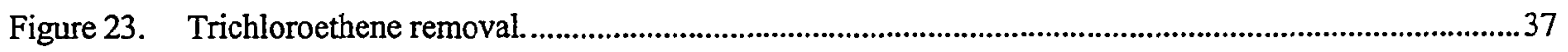

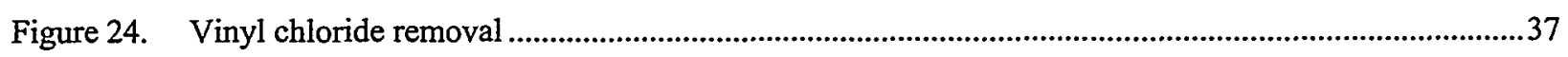

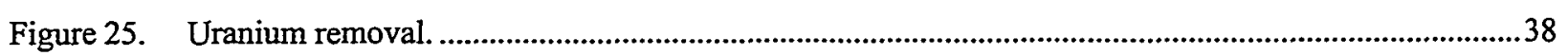

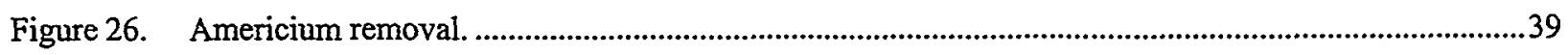

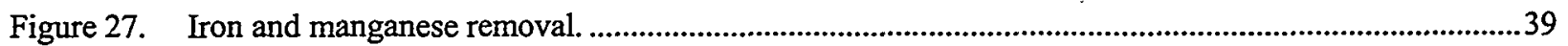

\section{Tables}

Table 1. Voc concentrations in grab groundwater collected at monitoring location 10797...................................9

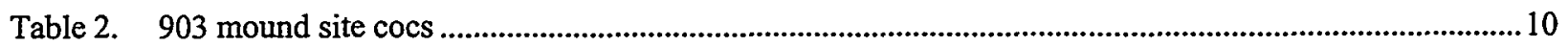

Table 3. Density and pore space data for column packings to be used in column tests.........................................12

Table 4. Sample and flow rate schedule for the first run with influents containing antimony, thallium and

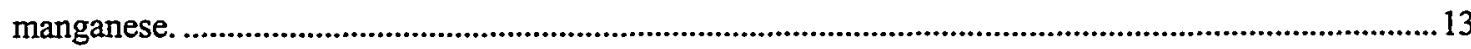

Table 5. Action levels for metal contaminants to be used in column experiments and highest reported concentrations in the ground waters at the rocky flats site..................................................................14

Table 6. Initial concentrations to be used in column experiments..................................................................15

Table 7. The make-up of the background matrix for column influents by salt type...............................................15

Table 8. The make-up of the background matrix for column influents b..............................................................15

Table A-1. Rocky flats barrier materials column studies. ..............................................................................................

Table A -2. Rocky flats barrier materials column studies. ......................................................................................

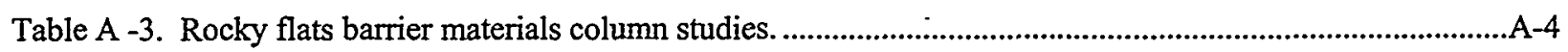

Table A -4. Rocky flats barrier materials column studies. .............................................................................

Table A -5. Rocky flats barrier materials column studies. ..............................................................................................

Table A -6. Rocky flats barrier materials column studies. ................................................................................................

Table A -7. Rocky flats barrier materials column studies. ...........................................................................................

Table A -8. Rocky flats barrier materials column studies. ..................................................................................9

Table B-1. Results of saturated hydraulic conductivity tests using iron foam pellets media .................................B-2

Table B -2. Results of saturated hydraulic conductivity tests using iron filings media. .........................................B-3

Table B -3. Results of saturated hydraulic conductivity tests using humasorb-cs media.......................................... B-4

Table C-1. The concentrations of volatile organic species present at various samplings of the column influents and effluents. 
Table C-2. THE CONCENTRATIONS OF VARIOUS HEAVY METAL SPECIES PRESENT AT SAMPLINGS OF THE COLUMN INFLUENTS AND EFFLUENTS.................................................................. -4

Table C-3. The concentrations of various radioactive species present at samplings of the column influents and

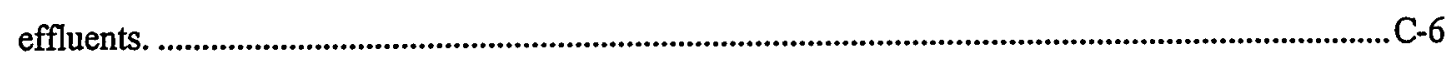




\section{INTRODUCTION}

The primary objectives of this project were to: (1) identify the optimum treatment media (reagent) for the 903 Mound Site at Rocky Flats Environmental Technology Site (RFETS) proposed reactive barrier installation; (2) develop design parameters including treatment residence time (tr), head loss across the chosen media and thus hydraulic gradient/profile of entire treatment system, treatment wall thickness and volume; and (3) conduct laboratory, pilot and full scale performance evaluation of the technology. The evaluation is divided into three parts: (1) a laboratory scale optimization of three potential reagents; and (2) a pilot-scale, field column study to verify laboratory results; and (3) performance monitoring and evaluation of the full scale reactive barrier

The DOE employed quite a team on the 903 Mound Reactive Barrier project including MSE Technology Applications, Inc. (MSE), Corps of Engineers, EnviroMetal Technologies Inc. (ETI), U.S. Environmental Protection Agency (EPA), and Sandia National Laboratories (SNL). SNL was responsible for laboratory, pilot and full scale testing and evaluation for the entire waste stream, ETI was responsible for laboratory optimization of the media to treat the organic contaminants, MSE and the Corps of Engineers were responsible for the design and construction, and the EPA was responsible for providing an independent assessment of the treatment system performance for the first year of operation - FY 1999.

\section{BACKGROUND}

\section{SITE DESCRIPTION}

The 903 Mound Site was the location of a subsurface disposal cell consisting of approximately 1400 unconfined drums. The drums contained depleted uranium and beryllium contaminated lathe coolant - high in solvent content; enriched uranium and plutonium and tetrachloroethene (PCE). Although the contamination source was removed in 1970, the groundwater in the area shows residual concentration of TCE; carbon tetrachloride mixed with uranium and minor amounts of plutonium and americium. In FY 1998 a reactive barrier was constructed at the 903 Mound Site. The system is designed to passively remediate the site in situ. This was only the second reactive barrier installation in the country for remediation of mixed waste contamination. The U.S. Department of Energy (DOE) primary objectives are to: (1) meet Rocky Flats Site cleanup goals; (2) show demonstrated cost savings and return on investment over baseline; and (3) assist with transfer of technology for deployment at other sites and subsequent commercialization. In order to meet the stated objectives the treatment system effectiveness and longevity of the barrier was closely monitored and reported.

\section{SITE GEOLOGY}

The Mound Site is located on relatively level ground along the southern edge of South Walnut Creek. The ground surface slopes downward to the North from the Mound Site. The surface deposits consist of approximately $12 \mathrm{ft}$. of Rocky Flats Alluvium, colluvium and slump deposits along with artificial fill, and undisturbed soil. Bedrock consisting of weathered claystone and 
minor sandstones of the Cretaceous Arapaho and Laramie Formations undulate approximately 15 to $20 \mathrm{ft}$. beneath the surface. The depth to groundwater is approximately $12 \mathrm{ft}$. (RMRS, 1997)

\section{CONTAMINANT DESCRIPTION}

Prior to installation of the 903 Mound Site reactive barrier treatment system, investigations in the vicinity indicated that 400 to 1,000 cubic yards of soil have residual volatile organic compounds (VOCs) contamination above Tier I Subsurface Soil Action Levels specified in the Rocky Flats Cleanup Agreement (RFCA) (DOE, 1996). For this reason the contamination has been termed the Mound Site Plume. Although the Mound Site Plume area has been well characterized, the boundaries of the plume are still not well defined (RMRS, 1997). Before construction of the treatment system to capture the Mound Site Plume, the groundwater was discharged as surface seeps and subsurface flow into South Walnut Creek Drainage. Total groundwater flow in the vicinity was estimated to range from 0.1 to $2 \mathrm{gpm}$. Groundwater samples for the plume are collected at monitoring location 10797. Results from one grab sample are shown in Table 1. In addition radioactive contaminants have been found above Colorado Water Quality Standards.

Table 1. VOC concentrations in grab groundwater collected at monitoring location 10797.

\begin{tabular}{|c|c|c|c|c|c|}
\hline Contaminant & $\begin{array}{c}\text { Minimum } \\
(u \mathrm{~g} / \mathrm{l})\end{array}$ & $\begin{array}{c}\text { Maximum } \\
(u \mathrm{~g} / \mathrm{l})\end{array}$ & $\begin{array}{c}\text { Average } \\
(u \mathrm{~g} / \mathrm{l})\end{array}$ & $\begin{array}{c}\text { Number of } \\
\text { Detections }\end{array}$ & $\begin{array}{c}\text { Colorado Water Quality } \\
\text { Standard }(u \mathrm{~g} / \mathrm{l})\end{array}$ \\
\hline Vinyl Chloride & nd & 55.0 & 13.0 & 5 & 2 \\
\hline $\begin{array}{c}1,1- \\
\text { Dichloroethene }\end{array}$ & nd & 94.2 & 18 & 8 & 70 \\
\hline $\begin{array}{c}\text { Cis-1,2- } \\
\text { Dichloroethene }\end{array}$ & nd & 808.0 & 169.0 & 9 & 5 \\
\hline $\begin{array}{c}\text { Carbon } \\
\text { tetrachloride }\end{array}$ & nd & 6.6 & 0.8 & 1 & 5 \\
\hline Trichloroethene & nd & 844 & 195 & 9 & 5 \\
\hline Tetrachloroethene & nd & 261 & 66 & 8 & 5 \\
\hline Dichloromethane & NA & NA & NA & NA & 8 \\
\hline Trichloromethane & nd & 177 & 17 & 6 & 200 \\
\hline $\begin{array}{c}1,1,1- \\
\text { Trichloroethane }\end{array}$ & NA & NA & NA & NA & 5 \\
\hline
\end{tabular}

Notes: $u g / 1$ Micrograms per liter

NA Not Analyzed

ndNondetect

Colorado Water Quality Standards for Segment 5 of Big Dry Creek required by the Rocky Flats Cleanup Agreement (DOE, 1996)

Source: RMRS 1997

The RFETS personnel determined that the following COCs were of primary concern for the 903 Mound Site study (Table 2). Additional contaminants were given consideration in order to enhance the technological application for other sites. 


\begin{tabular}{|c|c|c|}
\hline \multicolumn{3}{|c|}{ Table 2. 903 Mound Site COCs } \\
\hline Contaminants & $\begin{array}{c}\text { Parts/Billion in 903 Mound } \\
\text { Site Groundwater }\end{array}$ & $\begin{array}{c}\text { Action Level } \\
\text { (parts/billion) }\end{array}$ \\
\hline \hline Carbon Tetrachloride & 1004 & 5 \\
\hline Tetrachloroethene & 5496 & 5 \\
\hline Trichloroethene & 5250 & 5 \\
\hline Vinyl Chloride & 102 & 2 \\
\hline Uranium & $3.4 \mathrm{pCi} / \mathrm{L}$ & $3 \mathrm{pCi} / \mathrm{L}$ \\
\hline Americium & $0.25 \mathrm{pCi} / \mathrm{L}$ & $0.15 \mathrm{pCi} / \mathrm{L}$ \\
\hline
\end{tabular}

Note: Contaminant concentrations are highest expected concentrations.

\section{TECHNOLOGY DESCRIPTION}

The 903 Mound Site reactive barrier system is essentially a funnel and gate concept, consisting of HDPE impermeable funnel sections that direct the water into the gate which is a collection sump that overflows via gravity to baffled plug flow reactors with iron filings as the treatment media. The entire system is passive in nature (gravity flow) and constructed in situ.

Critical system performance parameters that need to be evaluated over time are: (1) contaminant treatment effectiveness; (2) changes in hydraulic conductivity (head loss) across the treatment media; (3) longevity of iron media (biological/precipitation fouling and/or passivation are potential problems); and (4) contaminant fate (can the contaminant re-mobilize).

Prior to installation of the 903 Mound PRB, only six commercial reactive barriers had been installed at various sites but, only one is being used to treat an inorganic compound (chromium) while the other five are treating organic contaminants. As a result of the success of the 903 Mound treatment, the Rocky Flats Environmental Technology Center constructed two additional reactive barriers at the East Trenches Site and the Solar Ponds Plume. Also, there are six additional sites that reactive barrier technology is being considered as the remedial method, contingent upon the effectiveness at the 903 Mound Site, Solar Pond, and East Trenches barriers. Consequently, future deployments and subsequent commercialization of this technology hinged on data collection at the 903 Mound Site.

\section{TREATMENT SYSTEM CHEMISTRY}

The removal mechanisms for the VOCs and the inorganic compounds vary and are briefly described in the following sections:

\section{Inorganic Compound Removal}

The inorganic compounds (metals and radionuclides) present in the 903 Mound Site Plume are removed by reductive precipitation. The treatment reagent/media - iron filings (zero valent ironZVI) creates a reducing environment where the inorganic contaminants form insoluble phases. These reactions are all $\mathrm{pH}$ dependent. Uranium precipitates as uraninite if the oxidation state is low enough. The concentration of carbonates, calcium, magnesium, dissolved oxygen and others in the groundwater system have an impact on what complexes or precipitates will form. It is 
essential that preliminary studies on the geochemistry of the groundwater system are evaluated to determine whether the potential formation of these mineral complex precipitates will adversely affect the performance of the reactive barrier by plugging off the porosity. Currently it is felt that creating a gradual or tapered reducing zone can help eliminate the potential clogging at the interface between the reactive media and the indigenous soil. This can be achieved by placing a porous material such as pea gravel upgradient of the reactive barrier. ZVI is gradually mixed with in an increasing percentage to cause a gradual-reducing zone with high porosity for precipitate formation.

\section{Organic Compound Removal}

The granular ZVI oxidizes as groundwater flows past, releasing electrons creating a reducing environment. The hydrocarbon-chloride bonds in the chlorinated contaminants become unstable and break apart. The breakdown is sequential, i.e., forming less chlorinated compounds and releasing chloride ions in the groundwater. The rate of the reaction depends primarily on the surface area of the iron or its abundance in the permeable reactive media (Gillham, 1997).

The dechlorination reaction is generally accompanied by a decrease in redox potential (Eh), a decrease in total dissolved solids (TDS), and an increase in $\mathrm{pH}$ for the groundwater system.

\section{LABORATORY STUDY}

The objective of the laboratory studies were to evaluate the contaminant removal effectiveness and hydraulic flow characteristics of the three potential treatment reagents. Results identified the optimum material for the full-scale demonstration of reactive barrier technology.

\section{Column Packings}

Three solid sorbants or solid reducing reagents that were potential treatment reagents for use in a reactive barrier at the 903 Mound Site, located on RFETS were examined in column tests. A literature search identified three reagents that had the potential to remove the contaminants of concern (COCs) from the 903 Mound Site groundwater plume. The proposed sorbants or reagents included high carbon steel iron filings, an iron-silica alloy in the form of a foam aggregate, and a pellicular humic acid based sorbant (Humasorb) mixed with sand. These three materials were packed into plexiglass columns $(2.54 \mathrm{~cm} \mathrm{ID} \mathrm{x} 12.7 \mathrm{~cm} \mathrm{Long})$ manufactured by Soil Measurement Systems. Figure 1 displays the laboratory column setup. 


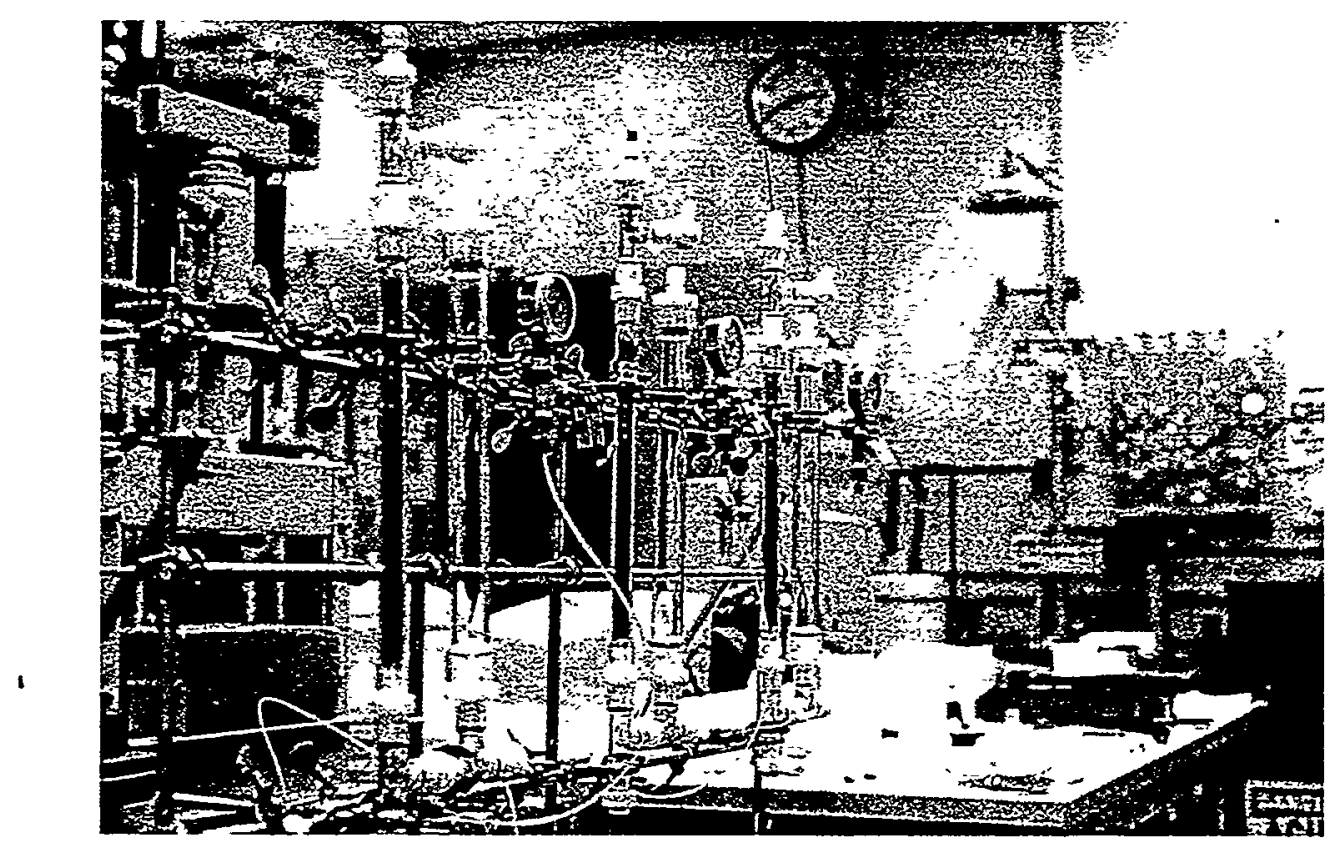

Figure 1. Laboratory Column Testing.

\section{Flow Rates}

The initial flow rate of influent through the column was chosen to reflect a contaminant resident time of approximately two hours. Based on measurements made for a set of two columns, Table 3 gives the average ratio of pore space to the total volume of the column packing. For columns of this size and type, a flow rate of $14-21 \mathrm{~mL} / \mathrm{hr}$ is roughly equivalent to a residence time of two hours. A flow rate in this range, $17.5 \mathrm{~mL} / \mathrm{hr}$, was chosen for start up.

Table 3. Density and Pore Space Data for Column Packings to Be Used in Column Tests.

\begin{tabular}{lccc}
\hline & $\begin{array}{c}\text { Pore Space } \\
\text { Sorbant or Reagent }\end{array}$ & $\begin{array}{c}\text { Bulk Density } \\
(\mathrm{g} / \mathrm{mL})\end{array}$ & $\begin{array}{c}\text { Material Density } \\
(\mathrm{g} / \mathrm{mL})\end{array}$ \\
\hline Iron Filings & 65.5 & 2.74 & 7.97 \\
Iron-Silica Alloy & 69.8 & 2.18 & 7.25 \\
Humasorb/sand & 43.5 & 1.43 & 2.52 \\
\hline
\end{tabular}

The specific objective of these experiments was to determine breakthrough concentrations of contaminants through the column at various flow rates. For the concentrations of contaminants used in this experiment it was assumed that the column capacity is many times greater than the amount of contaminant pumped through the column. Thus, breakthrough occurs because there is insufficient residence time for complete reduction or sorption of the metal contaminant rather than insufficient capacity.

Initially, the columns were washed with $500 \mathrm{~mL}$ of deionized water at a flow rate of 230-250 $\mathrm{mL} / \mathrm{hr}$. The deionized water rinse was used to strip loosely sorbed ions from the column 
packings and to remove air bubbles before the synthetic ground water samples were pumped through the columns. After the rinse was completed the columns were removed from the assembly and weighed, taking care not to siphon water from the columns.

The columns were incorporated once again into the column assembly and influent lines were connected to the influent reservoir containing the Rocky Flats synthetic water sample. The peristaltic pump was set to deliver influent at a rate of $17.5 \mathrm{~mL} / \mathrm{hr}$. The system was permitted to equilibrate at this initial flow rate for 12 hours before the first sample was taken. The first sample was taken after the equilibration step. To retrieve a 500-mL or larger sample, effluents were collected over a 32-hour period. Flow rates were increased over the course of the experiment several times. Each time, an equilibration step was used before taking a sample. The sampling schedule for column FE-1 is given in Table 4. Sampling the effluents of other columns was performed in a similar manner.

\begin{tabular}{|c|c|c|c|c|c|}
\hline $\begin{array}{c}\text { Line } \\
\text { Number }\end{array}$ & Action & $\begin{array}{l}\text { Time from Start } \\
(\mathrm{hr})\end{array}$ & $\begin{array}{l}\text { Flow Rate } \\
(\mathrm{mL} / \mathrm{hr})\end{array}$ & $\begin{array}{c}\text { Sample } \\
\text { Size } \\
\text { (mL) }\end{array}$ & $\begin{array}{l}\text { Cumulative } \\
\text { Volume } \\
\text { (mL) }\end{array}$ \\
\hline 1 & Equilibration 1 & $00: 00-14: 00$ & 17.3 & 243 & 243 \\
\hline 2 & Sample 1 & $14: 00-46: 00$ & 17.0 & 543 & 786 \\
\hline 3 & Equilibration 2 & $46: 00-51: 00$ & 47.8 & 239 & 1025 \\
\hline 4 & Sample 2 & $51: 00-63: 00$ & 48.2 & 579 & 1604 \\
\hline 5 & Equilibration 3 & $63: 00-66: 00$ & 85.2 & 255 & 1859 \\
\hline 6 & Sample 3 & $66: 00-72: 00$ & 84.2 & 505 & 2364 \\
\hline 7 & Equilibration 4 & $72: 00-74: 00$ & 120 & 239 & 2603 \\
\hline 8 & Sample 4 & $74: 00-78: 30$ & 120 & 540 & 3143 \\
\hline 9 & Equilibration 5 & $78: 30-80: 30$ & 147 & 294 & 3437 \\
\hline 10 & Sample 5 & $80: 30-84: 00$ & 152 & 533 & 3970 \\
\hline 11 & Equilibration 6 & $84: 00-84: 30$ & 182 & 273 & 4243 \\
\hline 12 & Sample 6 & $84: 30-87: 30$ & 184 & 552 & 4795 \\
\hline 13 & Equilibration 7 & $87: 30-88: 45$ & 217 & 272 & 5067 \\
\hline 14 & Sample 7 & $88: 45-91: 15$ & 215 & 539 & 5606 \\
\hline
\end{tabular}

\section{Contaminants}

Radionuclides which were measured at levels exceeding the Rocky Flats Tier II action levels were the focus of our investigation. These include uranium 238, americium 241, and plutonium 239. The Tier II action levels and the starting concentrations of these metals in the column influents are listed in Tables 5 and 6 . A single sample solution of these three species was prepared by Lovelace Biomedical and Environmental Research Institute and delivered in a 100$\mathrm{mL}$ polypropylene bottle. It was prepared in concentrated form and added to 20 liters of the synthetic Rocky Flats ground water to produced 20 liters of sample influent that meets the concentration criteria indicated in Table 6. The $\mathrm{pH}$ of the synthetic Rocky Flats ground water was measured before and after addition of the sample concentrate to insure that the buffering capacity of the ground water was sufficient to absorb acid from the sample and maintain a 
neutral $\mathrm{pH}$. No additional $\mathrm{pH}$ adjustment of the sample was necessary since the final $\mathrm{pH}$ was between 7.3 and 7.9 .

The synthetic ground water was prepared from various inorganic salts to produce a background matrix for the metal sample solution similar to ground waters in the 903 Mound Site at Rocky Flats. Tables 7 and 8 give the make-up of the background electrolytes that were used for all column influents.

In addition to the three radionuclides mentioned, non-radioactive metals in concentrations exceeding the Tier II action levels were used in separate column studies. These included manganese, antimony, and thallium. A single eluent with these three metals was made from purchased and prepared 1000-ppm standards in dilute nitric or hydrochloric acid. The same background matrix composition as the eluents containing the radionuclides was used (Tables 7 and 8).

\begin{tabular}{|c|c|c|c|c|}
\hline $\begin{array}{c}\text { Metal } \\
\text { Contaminant }\end{array}$ & $\begin{array}{l}\text { Highest } \\
\text { Reported } \\
\text { Activity }\end{array}$ & $\begin{array}{c}\text { Highest } \\
\text { Reported Conc }\end{array}$ & $\begin{array}{c}\text { Tier II Action } \\
\text { Level Activities }\end{array}$ & $\begin{array}{r}\text { Tier II Action } \\
\text { Level Conc }\end{array}$ \\
\hline \multicolumn{5}{|l|}{ Americium } \\
\hline \\
\hline 239 & $0.18 \mathrm{pCi} / \mathrm{L}$ & $2.90 \mathrm{pg} / \mathrm{L}$ & $0.151 \mathrm{pCi} / \mathrm{L}$ & $2.43 \mathrm{pg} / \mathrm{L}$ \\
\hline 240 & $0.18 \mathrm{pCi} / \mathrm{L}$ & $0.79 \mathrm{pg} / \mathrm{L}$ & $0.151 \mathrm{pCi} / \mathrm{L}$ & $0.659 \mathrm{pg} / \mathrm{L}$ \\
\hline \multicolumn{5}{|l|}{ Uranium } \\
\hline 238 & $3.02 \mathrm{pCi} / \mathrm{L}$ & $8.96 \mu \mathrm{g} / \mathrm{L}$ & $0.768 \mathrm{pCi} / \mathrm{L}$ & $2.28 \mu \mathrm{g} / \mathrm{L}$ \\
\hline 233 & $3.40 \mathrm{pCi} / \mathrm{L}$ & $0.348 \mu \mathrm{g} / \mathrm{L}$ & $2.98 \mathrm{pCi} / \mathrm{L}$ & $0.305 \mathrm{ng} / \mathrm{L}$ \\
\hline 234 & $3.40 \mathrm{pCi} / \mathrm{L}$ & $0.543 \mu \mathrm{g} / \mathrm{L}$ & $2.98 \mathrm{pCi} / \mathrm{L}$ & $0.476 \mathrm{ng} / \mathrm{L}$ \\
\hline Antimony & & $16.0 \mu \mathrm{g} / \mathrm{L}$ & & $6 \mu \mathrm{g} / \mathrm{L}$ \\
\hline Manganese & & $339.2 \mu \mathrm{g} / \mathrm{L}$ & & $183 \mu \mathrm{g} / \mathrm{L}$ \\
\hline Thallium & & $4.6 \mu \mathrm{g} / \mathrm{L}$ & & $2 \mu \mathrm{g} / \mathrm{L}$ \\
\hline
\end{tabular}


Table 6. Initial Concentrations to Be Used in Column Experiments.

\begin{tabular}{lcccc}
\hline $\begin{array}{c}\text { Metal } \\
\text { Contaminant }\end{array}$ & $\begin{array}{c}\text { Conc of } \\
\text { Column Influent }\end{array}$ & $\begin{array}{c}\text { Activity of } \\
\text { Column Influent }\end{array}$ & $\begin{array}{c}\text { Target Conc of } \\
\text { Column } \\
\text { Effluent }\end{array}$ & $\begin{array}{c}\text { Target Activity } \\
\text { of Column } \\
\text { Effluent }\end{array}$ \\
\hline $\begin{array}{l}\text { Americium } \\
241\end{array}$ & $5 \mathrm{pg} / \mathrm{L}$ & $17.4 \mathrm{pCi} / \mathrm{L}$ & 0.042 & $0.145 \mathrm{pCi} / \mathrm{L}$ \\
$\begin{array}{l}\text { Plutonium } \\
239\end{array}$ & $50 \mathrm{pg} / \mathrm{L}$ & $3.11 \mathrm{pCi} / \mathrm{L}$ & $2.43 \mathrm{pg} / \mathrm{L}$ & $0.151 \mathrm{pCi} / \mathrm{L}$ \\
$\begin{array}{l}\text { Uranium } \\
238\end{array}$ & $50 \mu \mathrm{g} / \mathrm{L}$ & $16.7 \mathrm{pCi} / \mathrm{L}$ & $2.28 \mu \mathrm{g} / \mathrm{L}$ & $0.768 \mathrm{pCi} / \mathrm{L}$ \\
$\begin{array}{l}\text { Antimony } \\
\text { Manganese }\end{array}$ & $100 \mu \mathrm{g} / \mathrm{L}$ & & $\begin{array}{r}6 \mu \mathrm{g} / \mathrm{L} \\
18 \mu \mathrm{g} / \mathrm{L}\end{array}$ \\
Thallium & $500 \mu \mathrm{g} / \mathrm{L}$ & & $2 \mu \mathrm{g} / \mathrm{L}$ & \\
\hline
\end{tabular}

Table 7. The Make-up of the Background Matrix for Column Influents by Salt Type.

\begin{tabular}{lccc}
\hline Electrolyte Salt & Molecular Weight & Concentration (M) & Grams/20-Liter \\
\hline $\mathrm{NaHCO}_{3}$ & 84.01 & $3.00 \times 10-3$ & 5.041 \\
$\mathrm{MgCO}_{3}$ & 84.32 & $1.00 \times 10-3$ & 1.686 \\
$\mathrm{CaSO}_{4}-2 \mathrm{H}_{2} \mathrm{O}$ & 172.10 & $1.20 \times 10-3$ & 4.130 \\
$\mathrm{CaCI}_{2}-2 \mathrm{H}_{2} \mathrm{O}$ & 147.02 & $1.00 \times 10-3$ & 2.940 \\
$\mathrm{KCI}$ & 74.56 & $0.05 \times 10-3$ & 0.0746 \\
$\mathrm{HCI}(36-37 \%)$ & 36.46 & $1.00 \times 10-3$ & 1.967 \\
\hline
\end{tabular}

Table 8. The Make-up of the Background Matrix for Column Influents $b$.

\begin{tabular}{|c|c|c|c|c|c|}
\hline Cations & F. Wt. & $\mathrm{ppm}$ & Anions & F. Wt. & Ppm \\
\hline $\mathrm{Ca}^{2+}$ & 40.08 & 88.2 & $\mathrm{SO}_{4}^{2-}$ & 96.06 & 115.3 \\
\hline $\mathrm{Mg}^{2+}$ & 24.31 & 24.3 & $\mathrm{Cl}^{-}$ & 35.45 & 108.1 \\
\hline $\mathrm{Na}^{+}$ & 22.99 & 69.0 & $\mathrm{HCO}_{3}^{-}$ & 61.02 & 244.1 \\
\hline $\mathrm{K}^{+}$ & 39.10 & 2.0 & & & \\
\hline
\end{tabular}




\section{Procedure}

Columns manufactured by Soil Measurement systems were used. All columns were dry packed. The column material was compressed by lightly tapping the column on a rigid surface for several minutes until no additional compacting was observed. Sufficient material was added to completely fill a $1 \times 5$-inch column without leaving void space between the bed support and the column packing. The columns were weighed before and after packing. Teflon filters $(10 \mu \mathrm{m}$, manufactured by MSI) were installed between the packing support and the packing material. Figure 2 shows the loaded columns.

Three columns, one of each material, were run simultaneously. The sample influent for a given run was stored in a $20-\mathrm{L}$ polyethylene carboy with faucet. The intake tubing for all three columns was placed through the lid of the container so that the ends rested on the bottom of the carboy. The tubing leading to and from the column, and the fittings were made of Teflon; however, silicon peristaltic tubing was used. The influents were pumped through the column from bottom to top with a Rainin (Rabbit model) peristaltic pump. Peristaltic tubing was used which was capable of delivering flow rates of 5 to $.250 \mathrm{~mL} /$ hour. The reservoir, tubing and fittings were pre-soaked with 0.10 $\mathrm{N}$ HCI to remove adsorbed ions, then rinsed several times with deionized water. After rinsing with deionized water, the tubing was fit to the column and $500 \mathrm{~mL}$ of deionized water was pumped through the column at a high flow rate. The deionized water was

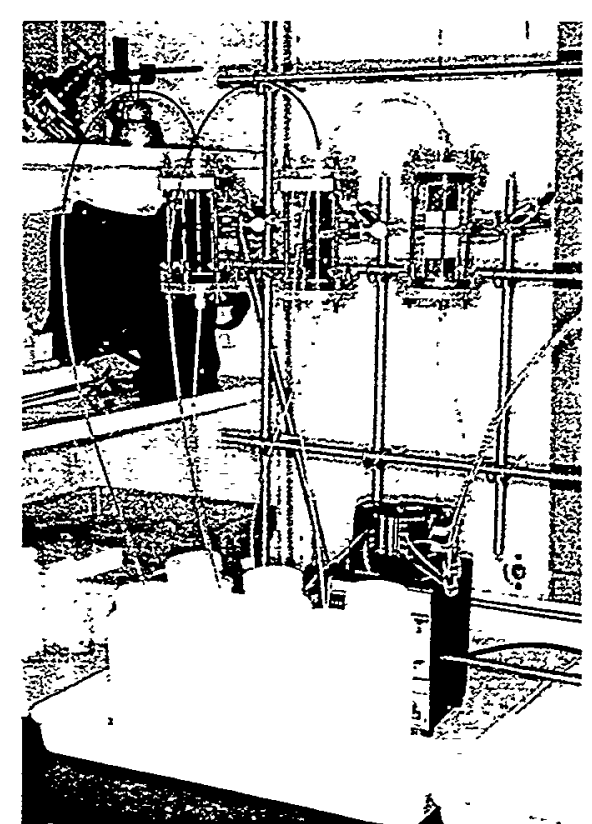

Figure 2. Laboratory column setup. replaced by the metal-ion influent and pumped through the column at an initial flow rate of about $17.5 \mathrm{~mL} / \mathrm{hr}$.

The effluents were collected in 1000-mL polypropylene sample bottles over concentrated nitric acid. A 2-mL aliquot of Fisher optima grade nitric acid was placed into the empty sample bottle and the bottle was weighed before collecting the sample. After the sample was collected, the bottles were weighed once again. Seven effluent samples were taken for each column. Each consecutive sample was collected at a progressively higher flow rate. Influent samples were collected concurrently with the effluent samples. Effluents from column studies with nonradioactive metals were analyzed by ICP mass spectroscopy at Sandia National Laboratories. Effluents from column studies that contained radionuclides were analyzed by alpha spectrometry by Lovelace Biomedical and Environmental Research Institute.

\section{Results and Discussion}

The results are summarized in Appendix A in eight tables (Tables A-1, A-2, A-3, A-4, A-5, A-6, A-7, and A-8) and three charts (Figures 3, 4, and 5) following this section of the report. The data are grouped by run number with four tables presented for each run. The first table in each group gives concentration values for influent samples. The remaining three tables in each group, one 
table for each of the reagents, contain data related to the concentration of metals in the effluents. The influent of run 1 was spiked with antimony, manganese, and thallium; and that for run 2 was spiked with americium, plutonium and uranium.

The concentrations of antimony, manganese, and thallium remain fairly stable throughout the run; however, there is some loss of the metal spike likely due to sorption on the walls of the influent reservoir. Sorption of metal ions is generally a problem in basic solutions; thus the loss of nearly 25 percent of the initial antimony spike is credible. For a given metal and column, a percentage breakthrough was calculated based on the ratio of the effluent concentration to the ratio of the average influent concentration. The percentages are plotted versus residence time. All three reagents, Connelly iron fillings, iron-silica form, and Humasorb reduced thallium concentrations to well below action levels in a short residence time. Antimony was effectively eliminated only by the Connelly iron. The Humasorb and iron silica foam performed poorly for sorbtion of antimony. There is some evidence that the iron-silica foam contains a small percentage of antimony that elutes as the material oxidizes. The most effective reagent for the extraction of manganese is Humasorb that eliminates nearly all the metal from the influent in a residence time of 15 minutes. Both iron reagents appear to contain large amounts of manganese. The manganese elutes as the iron oxidizes resulting in as much as a 5-fold increase in the manganese concentration in the effluent rather than a decrease.

In separate column studies, the influent was spiked with uranium, americium, and plutonium. It was decided after viewing the results that the plutonium numbers could not be trusted. Control samples associated with the these results showed elevated levels of plutonium indicating there was some contamination which occurred during analysis. However, the uranium and americium numbers should be valid as the controls indicate. In the influent, the concentration of uranium is constant during much of the run, but increases slightly for the last few samples. The americium concentration decreased rapidly during the first 48 hours of the run and then levels off at about 25 percent of the initial concentration. Americium tends to sorb on surfaces at neutral to high $\mathrm{pH}$ according to experts at Sandia who work with americium on a regular basis. The plutonium results were difficult to interpret; consequently, little may be inferred from these numbers, nonetheless, this concentration also appears to drop with increasing time. The decrease is most certainly due to sorption of the metals on the influent reservoir surface. Both americium and plutonium are present in amounts in the parts per quadrillion range; consequently, a small amount of surface sorption results in a large decrease in the concentration of these analytes.

Uranium is removed by both iron reagents even at very high flow rates. On the other hand, Humasorb is almost ineffective at sorption of uranium. At low flow rates, a residence time of 85 minutes, about 50 percent of the uranium is removed. At a residence time of 33 minutes or less, uranium passes through the column too quickly for an appreciable decrease in the metal concentration to occur. For sorption of americium, all three reagents are effective. Little or no americium was detected in the influents even at high flow rates. As for plutonium, the values follow no evident trend. Some values are below the action level, other values are much higher than the action level. Based on ten blanks, the average amount of plutonium contamination was $0.09 \mathrm{pCi} / \mathrm{L}$ per sample. However, the error was not systematic. Same blanks were highly contaminated; whereas, others were completely clean. 


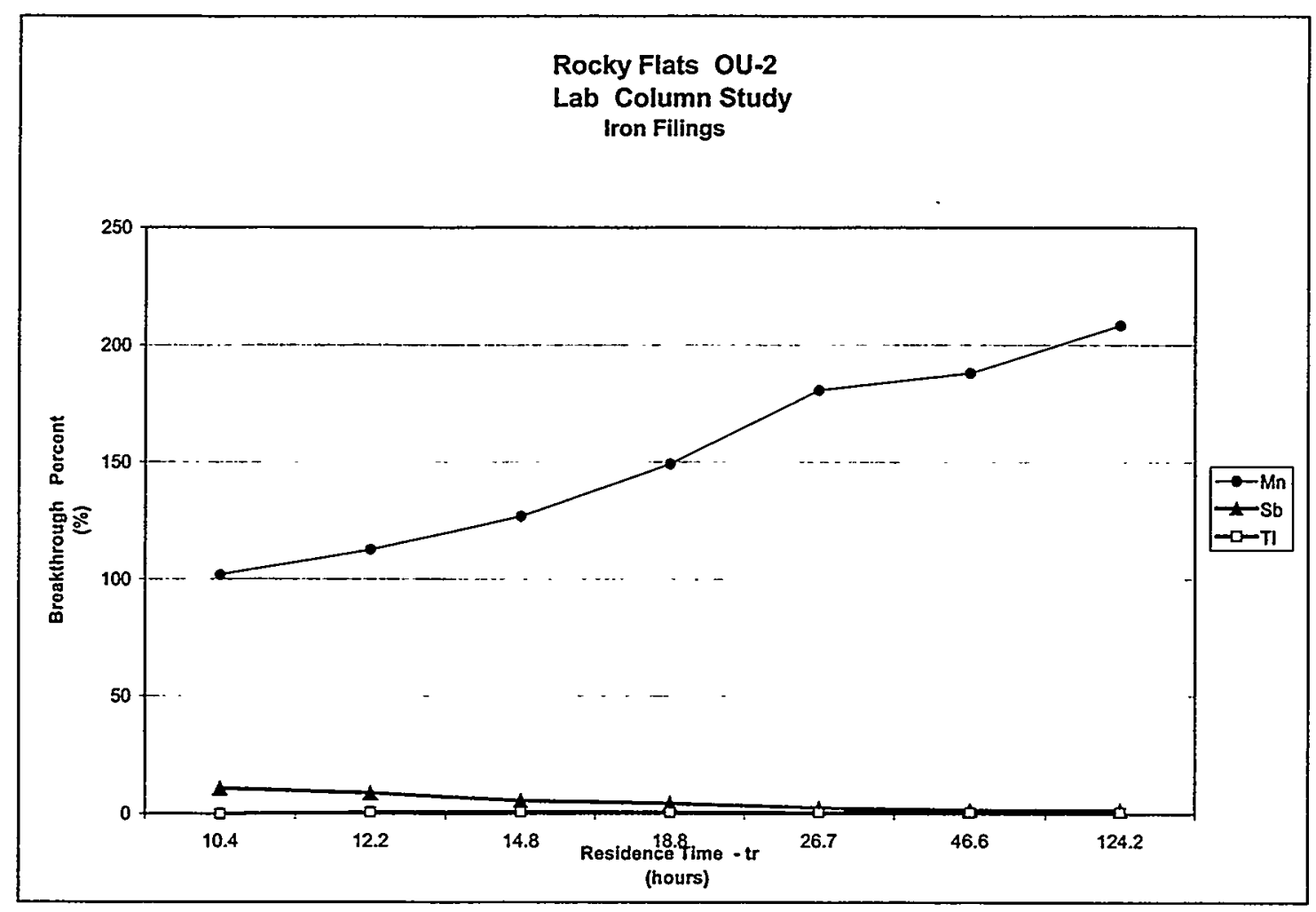

Figure 3. Iron Filings Lab Column Results.

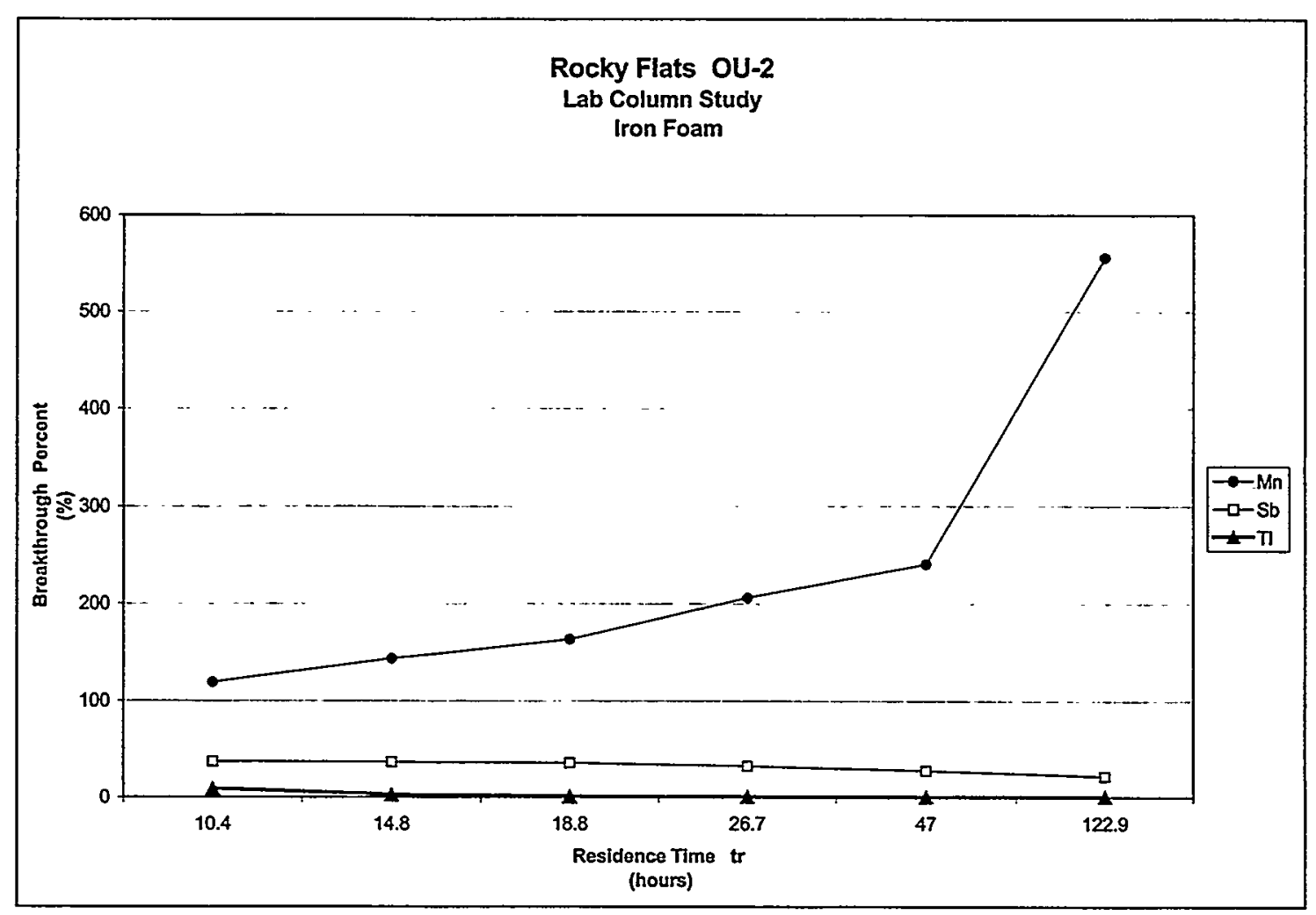

Figure 4. Iron Foam Lab Column Results. 


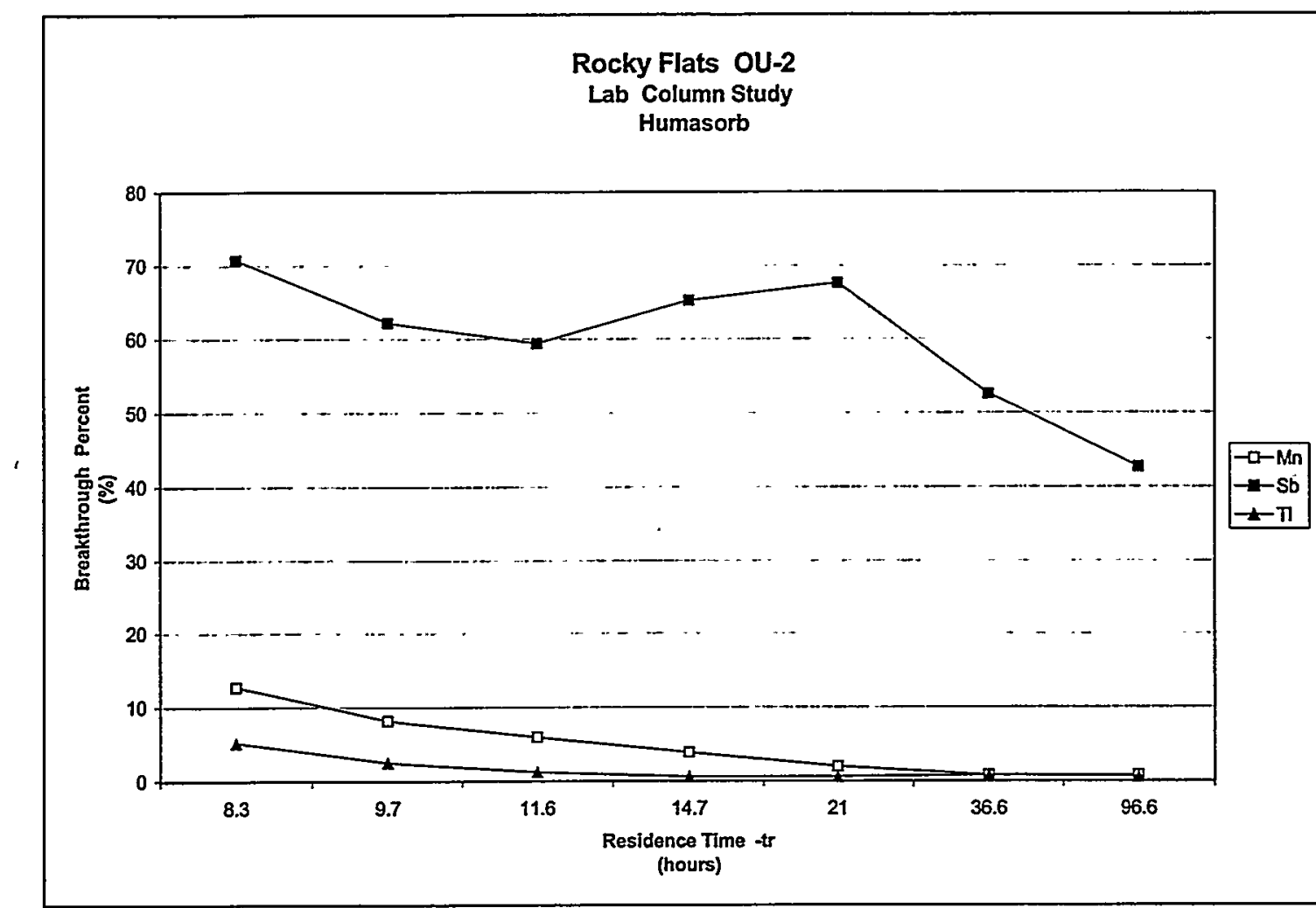

Figure 5. Humasorb Lab Column Results.

\section{Conclusions}

Individual columns containing each potential reagent were evaluated to determine their effectiveness in the reduction of americium, plutonium, and uranium from synthetic ground waters at various flow rates and residence times. In very low concentrations americium and uranium are removed by columns containing either the clean iron fillings or the iron-silica foam when residence times exceed 15 minutes. It is likely that plutonium is also removed by both of these reagents, though this is not a certainty based on the results in this study. Humasorb, the third reagent investigated, does not appear to be effective for the removal of uranium when mixed with 80 percent sand (Arctech prepared the reagents with a 4 to 1 ratio of sand to Humasorb). In pure form, Humasorb may fair better and its cost is still quite low. When these same reagents were evaluated with influents containing antimony, manganese, and thallium, each showed some weakness. The iron reagents both contain high levels of manganese that is released as the iron oxidizes. The iron foam may contain a small amount of antimony that also shows up in the effluent. The Humasorb is excellent for sorption of manganese and thallium, but sorbs antimony at low efficiency. However, a solid bed of Humasorb may effectively remove all three heavy metals.

The primary COCs for the RFETS 903 Mound Site are U, PCE, TCE, and $\mathrm{CCl}_{4}$. Both iron filings and foam were favorable to the Humasorb in the lab removal effectiveness study. Also the $\mathrm{Ks}$ for the three media were all within an acceptable range; consequently, the iron foam and filings were given further consideration. The remaining consideration was cost and availability. Iron filings are less expensive and more readily available than the iron foam so the iron filings 
were chosen as the optimum media for further evaluation/validation in the pilot column-test study at the actual site.

\section{Saturated Hydraulic Conductivity Determination}

In a reactive barrier treatment system it is essential to understand the hydraulic flow characteristics of the treatment media. The media must have a higher saturated hydraulic conductivity (Ks) than the surrounding soil to avoid flow bypassing the system. Also the head loss across the media should be low enough to avoid unacceptable mounding of contaminated water upgradient of the treatment barrier which in effect would act as a bottleneck.

The Ks for each media was determined using a constant head flow apparatus (Figure 6). Each media was tested at three bulk densities to simulate various field conditions: 1) the bulk density when the sample was poured into the flow cell; 2) the higher bulk density when the media was vibrated into the flow cell; and 3) the bulk density when the sample was packed as tightly as possible using vibration and a hand ram. Appendix B - Tables B-1, B-2, and B-3 present the results for the three media samples at each of the bulk densities tested.

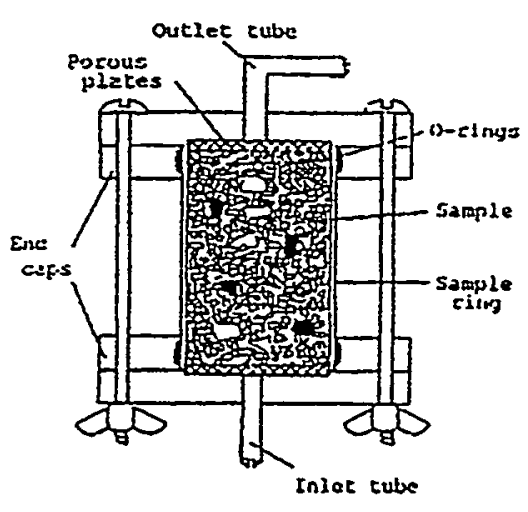

Elow Cell

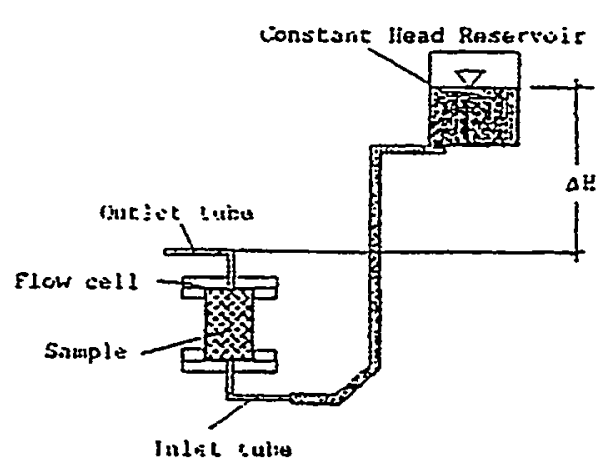

Constant head setup

Figure 6. Constant head and flow cell apparatus.

Tests on samples were begun after the samples were fully saturated and an apparent constant flow had been established. The tests were repeated after 12 hours ( 72 hours for the HumasorbCS media). After the second test, Ks had decreased slightly, with the greatest decrease occurring at the higher bulk densities. The saturated hydraulic conductivity (Ks) was calculated using:

$$
k_{s}=\frac{Q_{\mathrm{H}_{2} \mathrm{O}}}{A \cdot t} \cdot \frac{\Delta L}{\Delta H}=\frac{\text { mass }_{\mathrm{H}_{2} \mathrm{O}}}{A \cdot p_{\mathrm{H}_{2} \mathrm{O}}} \cdot \frac{\Delta L}{\Delta H}=\frac{\text { (outflow mass - tare) }}{A \cdot p_{\mathrm{H}_{2} \mathrm{O}} \cdot t} \cdot \frac{\Delta L}{\Delta H}
$$

where: outflow mass $=$ mass of flow through cell + container mass tare $=$ mass of container 


$$
\begin{aligned}
p_{\mathrm{H}_{2} \mathrm{O}} & =0.9978 \mathrm{~g} / \mathrm{cm}^{3} \\
\mathrm{~A} & =\text { area of the flow cell perpendicular to flow } \\
\Delta \mathrm{L} & =\text { length of flow cell perpendicular to flow } \\
\Delta \mathrm{H} & =\text { difference between inflow and outflow elevations }
\end{aligned}
$$

The flow medium used was a $0.0005 \mathrm{M}$ solution of $\mathrm{CaSO} 4$ in deionized water. This solution is used in most hydrologic testing of soils to minimize slaking and other effects. Its density is $0.9978 \mathrm{~g} / \mathrm{cc}$. This solution should not have an adverse effect on $\mathrm{Ks}$ for the purposes of this study.

\section{Conclusions}

The Ks for each respective media for design purposes was determined to be:

$\begin{array}{ll}\text { Iron foam } & 4 \times 10^{-2} \mathrm{~cm} / \mathrm{s} \\ \text { Iron filings } & 3 \times 10^{-2} \mathrm{~cm} / \mathrm{s} \\ \text { Humasorb-CS } & 1.5 \times 10^{-2} \mathrm{~cm} / \mathrm{s}\end{array}$

The higher the conductivity within a range, the better flow characteristics. A conductivity in the $10^{-1} \mathrm{~cm} / \mathrm{s}$ range would present a problem with requiring a longer flow path to meet the required treatment residence time. There is an ideal balance between the $\mathrm{Ks}$ value of the media, and the required residence time (tr) because these values relate to the volume of media required, which is directly related to project costs. All three media were low enough not to result in an excessive flow path length, yet are high enough to avoid substantial mounding of upgradient groundwater. Consequently, this parameter provided no differentiation of the three media with respect to choosing an optimum material, i.e., all three materials would provide acceptable $\mathrm{Ks}$ and $\mathrm{hL}$ values for the full-scale demonstration.

\section{PILOT FIELD COLUMN STUDY}

\section{Column Scale Field Validation}

Upon completion of the laboratory study that identified ZVI (iron filings) as the optimum treatment media for the Mound Site Plume, field columns were set up at the Mound Site to verify the ZVI media performance using actual site water. In addition head loss, saturated hydraulic conductivity were monitored to ensure that the proper parameters were given to the design team at the Corps of Engineers.

\section{Experimental}

Reagents, Instruments, and Apparatus

The columns were packed with pre-cleaned 40 mesh iron filings supplied by Connelly GMP Inc. Ultra-pure concentrated hydrochloric acid and nitric acid for the preservation of water samples were supplied by the contract Lab (Core Labs) with the sample containers. Calibration standards for measuring $\mathrm{pH}$ were purchased from Fisher and standards for measuring dissolved oxygen were obtained from Corning. A Corning model Checkmate 90 was used to measure influent and effluent $\mathrm{pH}$, dissolved oxygen, and conductivity. Mass measurements were made with Mettler 
scales models PM30-K and PM4800. Custom designed acrylic columns were made by Soil Measurement Systems to various lengths. Teflon bed filters were purchased from Micron Separations $(10 \pm \mathrm{m}$ pore size $\times 90 \mathrm{~mm}$ diameter disks). Influent water was pumped into columns with an eight channel Rainin peristaltic pump model Rabbit. All tubing was constructed of Teflon FEP (1/8" OD x 1/16" D) and fittings were made of Teflon PTFE, PEEK and KYNAR. Bag filters which were used to prevent particles from entering the intake lines were purchased from Knight Corporation ( $10 \pm \mathrm{m}$ pore size $\mathrm{x} 7$ " diameter $\mathrm{x} \mathrm{16"} \mathrm{length).} \mathrm{A} \mathrm{support} \mathrm{structure} \mathrm{for}$ the bag filters was constructed of polyethylene canvas purchased from Uniek (No 7 grid). The experimental setup and operation is shown in Figure 7.

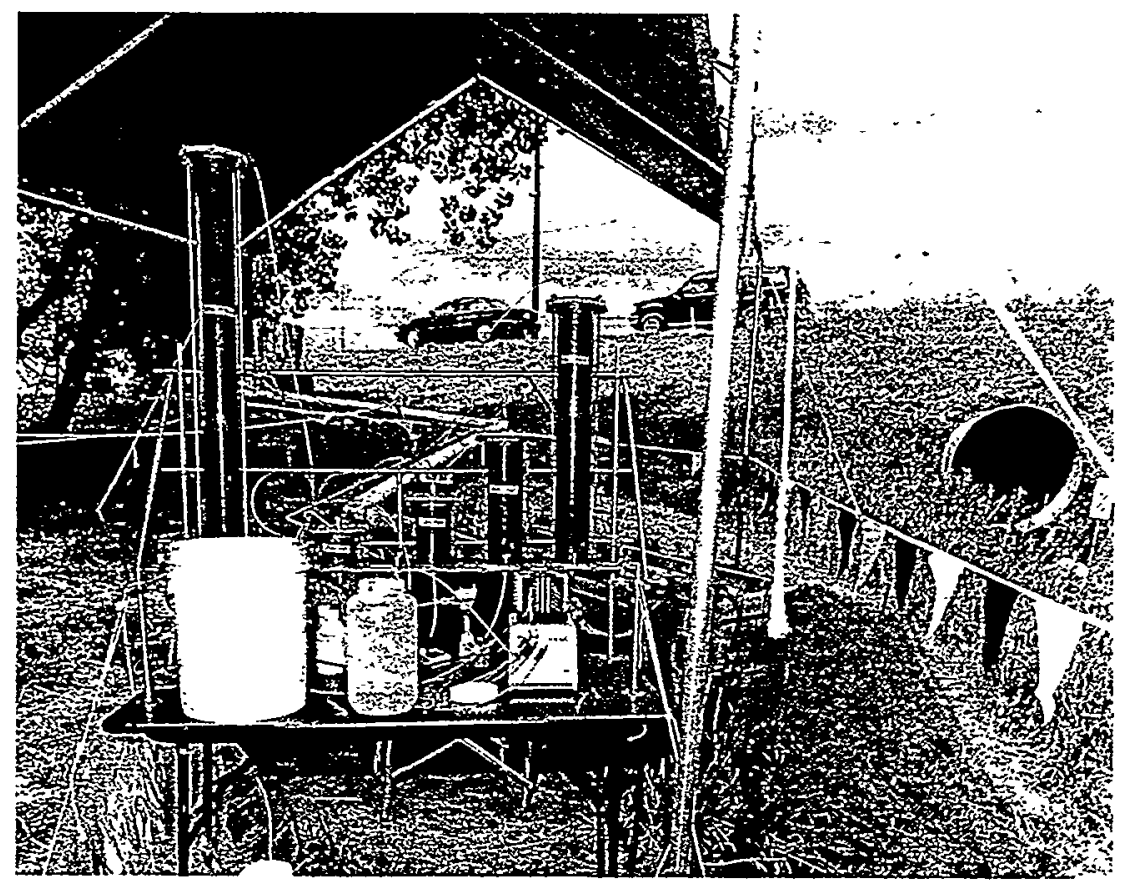

Figure 7. Pilot-scale field columns at RFETS 903 Mound Site.

\section{Procedure}

The columns were obtained from Soil Measurement systems in five lengths $(3.0,6.0,12.0,24.0$, and 36.0 inches) each 3.0 inches wide. Each column was cleaned, dried, and assembled without packing and then its mass was measured and recorded. A Teflon bed filter was placed on one end of the column and the support end plates attached before the columns were packed. Iron filings were scooped into the columns with occasional light tapping. When the bed was filled completely, the top plates were attached with the supporting rods. The entire apparatus was tapped vigorously against a rubber surface for several minutes to increase the packing density. The top plates were removed and additional filings were added to the column. These steps were repeated several times until a packing density between 2.6 and $2.7 \mathrm{~g} / \mathrm{mL}$ was obtained. At this density, very little additional settling of the bed occurs when the columns are jostled over time. After the packing was completed, the final mass of each column assembly was recorded. These results appear in Table 1. The columns were attached to a large aluminum lattice and bolted to a portable table that was positioned several feet from seep SWO59 at the Mound site. Pumps, tubing, valves, and fittings were fasten to the column assembly at the field site. The tubing ends 
that were placed in the seep collection sump well were covered with a bag filter. Bag filters were used because it was necessary to trap a large amount of suspended soil and organic matter without clogging the intake lines or causing a reduction in flow rates. To prevent the bag filter from collapsing on the intake lines, a cage-like supporting structure was constructed from polyethylene canvas and placed inside the bag filter. The intake lines were positioned inside the cage and the bag filter over the cage with the filter tightly gathered against the intake lines using cable ties.

A Teflon valve was installed between the pump and the column to prime the pump before filling the columns with influent from the seep. Flow rates were maximized (setting of 48.0) initially. The first effluent emerging from the largest column was sampled to determine the concentration of organic residues left from the cleaning process done by Connelly GMP. These same contaminants would be expected in the initial effluents emerging from the iron reactor during the field-scale project. With sight of the first effluent, the flow rate setting was reduced to a value of 12.0 and maintained for 16 hours. At that time, the pump was stopped. The columns were disconnected and plugged to prevent loss of the interstitial water. The entire column assemblies were weighted once again, then reconnected and the pumps started at the same flow rate setting.

After approximately 40 hours of operation, (the initial 16 hours plus an additional 24 hours to allow the columns to reach a steady state) the first set of samples were taken. For each set, six samples were collected, one effluent sample from each column and one influent sample. The configuration and length of the tubing used to sample the influent was identical to that for the columns except this line did not have a column attached to the end. Sample sets for three types of analysis were collected during the working hours. For volatile organic analysis, the samples were collected in 100-mL glass jars with Teflon liners. A 1/8" hole was drilled through the top into which the effluent line was placed. The jars were weighted before and after sampling and the starting and stopping times were recorded to determine the mass of sample and flow rates. After approximately 100 milliliters of sample was collected in each jar (this took about 45 minutes), the sample was quickly poured into two $40-\mathrm{mL}$ glass VOA vials, sealed, labeled and refrigerated immediately. An $\mathrm{HCl}$ preservative was used for these samples. For heavy metal analysis, narrow-mouth 125 -mL polyethylene bottles were used. A 1/8" hole was drilled through the top in which to place the effluent lines. Approximately $100 \mathrm{~mL}$ of sample was collected in a small amount of nitric acid preservative. The exact amount of sample was recorded by weighing the bottles before after sampling. Starting and stopping times were also recorded for the purpose of determining flow rates. When sampling was complete (about 45 minutes), the bottles were sealed with new tops, labeled and refrigerated immediately. Larger plastic bottles $(1000-\mathrm{mL})$ were used to collect samples for the radioactive metals assay. However, the sampling procedure was identical to that for the heavy metal assay. Between sampling for heavy metals and radioactive metals, approximately 100 milliliters of the column effluents and the influent were collected in a 100-mL glass container for the purpose of measuring dissolved oxygen levels and $\mathrm{pH}$. DO and $\mathrm{pH}$ levels were also measured directly on water that accumulated in the seep well.

On the afternoon of July 16,1997 , the pumps were started to begin the column studies. On the morning of July 18, about 40 hours later, the first set of samples was collected. Subsequent sets of samples were collected beginning on the mornings of July 22, July 23, and July 24. 
Radioactive metals samples were collected on the 18th, 22nd, and 24th. Volatile organic and heavy metal samples were collected on each day samples were taken.

\section{Results and Discussion}

Tables C-1, C-2, and C-3 in Appendix C contain the data collection from the field columns. Figures 8, 9 and 10 below exemplify the removal of COCs for the 903 Mound Site using ZVI.

Americium and plutonium are at such low levels at the 903 Mound Site that a change in the effluent concentration is not apparent; however, uranium is significantly removed from the column over time. Antimony and thallium are negligible in the influent and subsequent effluent, while iron is released in a large pulse that slowly comes back down to near zero. Manganese appears to be released gradually and continuously from the treatment system. It is thought that the manganese is liberated from the iron filings. Finally, the organic compounds of primary concern - TCE, PCE, and carbon tetrachloride are removed quite rapidly from the system, with the appearance of no additional bad actors. It is critical with organics that the retention or residence time is adequate to allow for complete degradation to avoid releasing intermediate byproducts downgradient. Environmental Technologies, Inc. (ETI) was responsible for determining the design residence time (tr) with respect to the organic COCs. They determined the tr to be a minimum of 15 hours. A treatment system design tr of 20 hours was used to ensure an adequate factor of safety (F.S.)

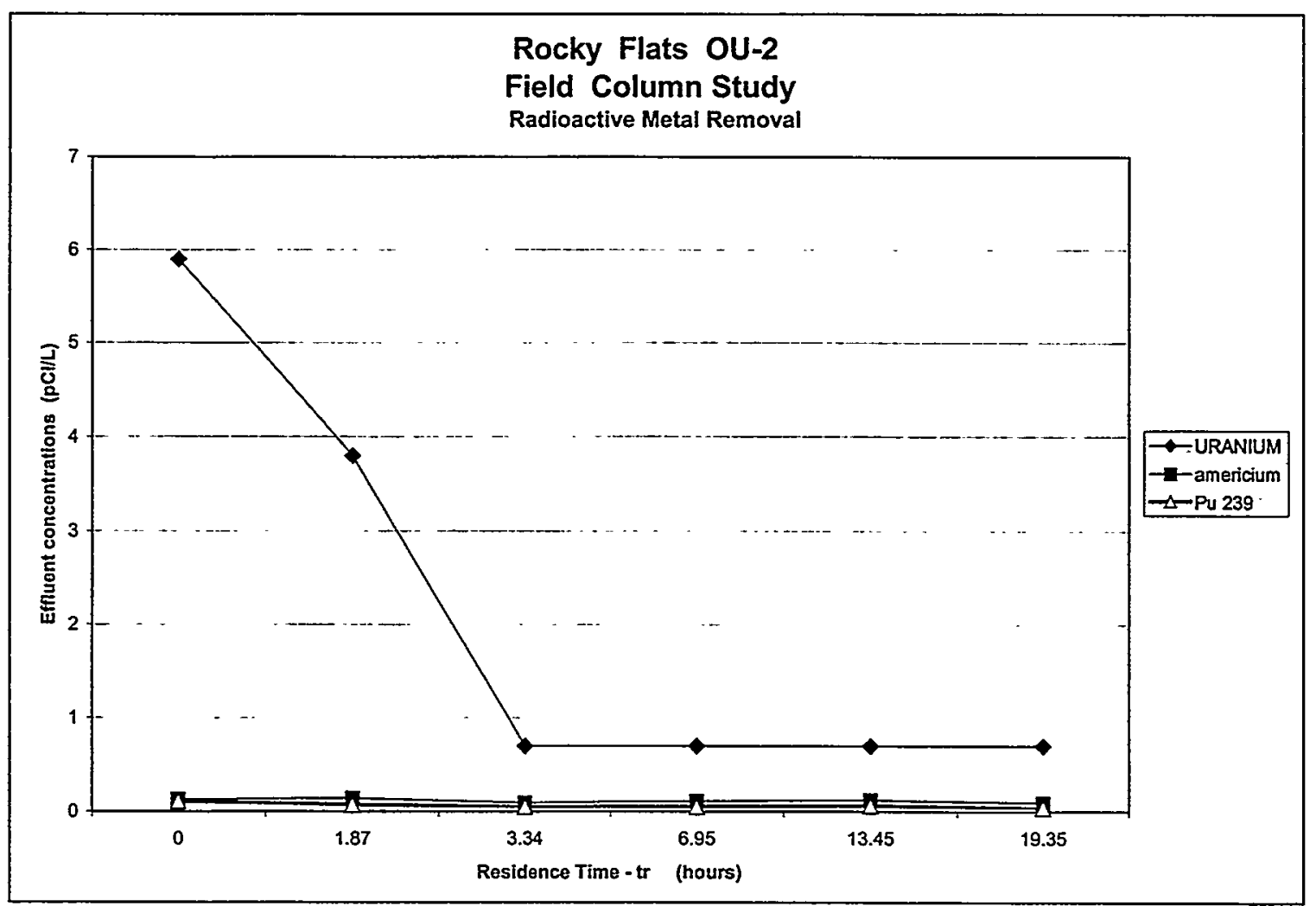

Figure 8. Radioactive Metals Removal. 


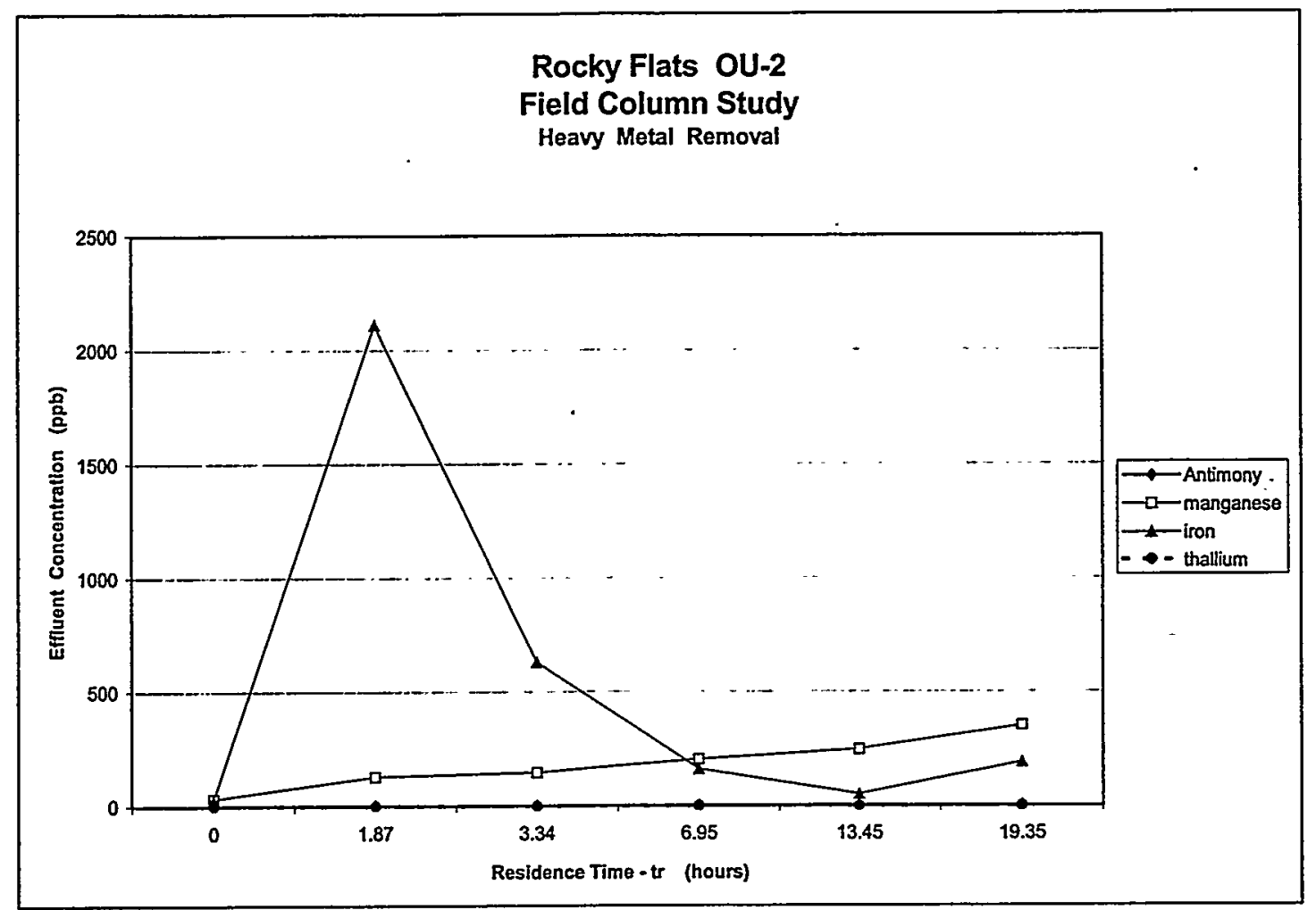

Figure 9. Heavy Metals Removal.

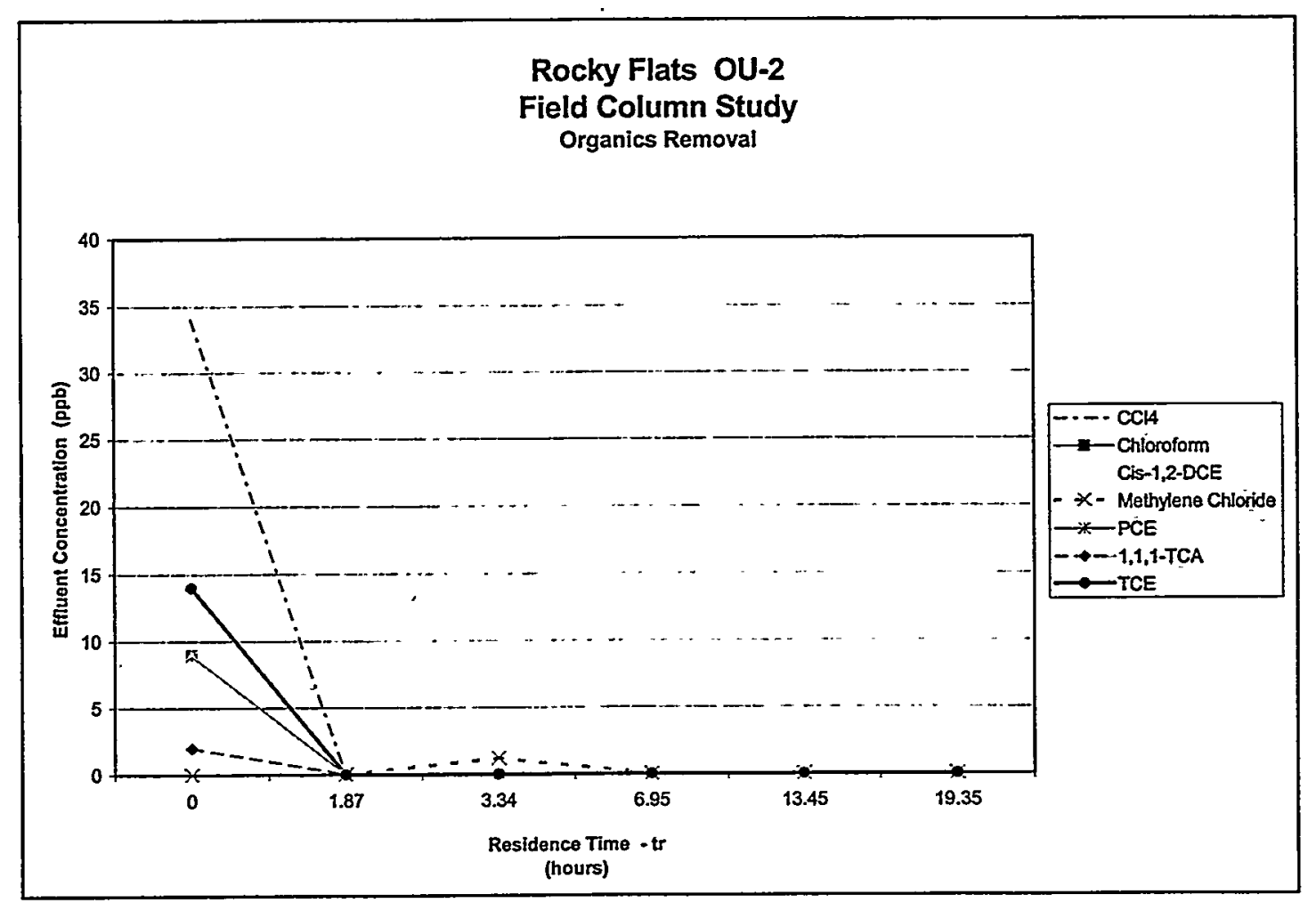

Figure 10. Organic Compounds Removal. 


\section{Conclusions}

In the pilot-scale, field-column studies the primary COCs - uranium, TCE, PCE, and CCl4 were removed to regulatory acceptable levels in 3.5 hours or less. Results from the full-scale barrier installation will be compared to the lab and pilot-scale studies. It is anticipated that the comparison will show that lab/pilot testing can provide reliable design parameters to engineers for full-scale reactive barrier designs.

The full-scale demonstration of this technology is designed to have a minimum of 20 hours of residence at a flow rate of $2 \mathrm{gpm}$. Sample ports on the full-scale system allowed for sampling along the flow path to better clarify the actual required residence time (tr). A more reliable tr value allows reactive barrier engineers the confidence to decrease the design Factor of Safety (F.S.). A decrease in the F.S. translates directly into less treatment media required which results in immediate cost savings for a reactive barrier project.

\section{FULL-SCALE REACTIVE BARRIER DESIGN AND CONSTRUCTION}

\section{Reactive Barrier Concept}

Conceptually reactive barriers are used to intercept and remove ground water contaminants before passing into the wider ecosystem. The barrier is constructed of benign reactive materials such as metallic iron that are used to breakdown or immobilize contaminants by redox reduction using ordinary chemical, physical, and/or biological means. Typically installations require a trench excavation below the depth of the aquifer, downstream from the plume; the trench is filled with the reactive media to form a treatment wall. Laboratory research has shown that iron filings appear to be the most economical viable treatment media that is technically adequate for the COCs at the 903 Mound Site Plume. After further review by interested parties, of the 903 Mound Site conditions, reactive barrier technology was chosen as the remediation methodology for the 903 Mound Site Plume. The site is ideally suited as one for the investigation of a relatively new technology since contaminant levels are low and there is no additional risk to the environment if the technology proves to be inadequate. As mentioned, reactive barrier installations to date typically involve the subsurface placement of iron media to effectively intercept the contaminated groundwater. Subsurface placement; however, does not easily allow for performance interpretation because aquifer effluent samples are difficult to gather and the condition of the barrier material cannot be easily observed. Consequently, a reactive barrier design that assisted scientific investigation was chosen.

\section{Reactive Barrier Design}

The project design parameters include given and to be determined (TBD) parameters. The given parameters include: flowrate $(\mathrm{Q})-0.1$ to $2 \mathrm{GPM}$; and an elevation head (gradient) of approximately 6 feet. The TBD parameters are: saturated hydraulic conductivity (Ks); required residence time for contaminant removal (tr); and the head loss across the media per unit length (hL).

MSE and the Corps of Engineers were primarily responsible for the design and construction of the 903 Mound Reactive Barrier. Sandia National Laboratories, ETI, EPA, and the RFETS 
personnel developed the TBD parameter input to aid in design and construction. MSE published a document summarizing the design and construction of the system. (MSE, 1999) The US Army Corps of Engineers published a document containing the Final Design Specifications for the project. (US Army Corps of Engineers).

The reactive barrier installation consists of a 230 -ft. wide relatively impermeable water collection wall formed with 100-mil high-density polyethylene (HDPE). The wall was placed in an open trench against the down gradient soil wall and sealed (keyed into the underlying aquitard) at the bottom with bentonite. The wall was placed approximately perpendicular (bisects) to the groundwater flow to maximize contaminated groundwater capture. A perforated collection pipe was placed in the trench bottom (above the bentonite/aquitard seal) to direct captured groundwater into a centrally located 48 -inch diameter collection vault (sump). Collected water backs up against the containment wall filling the sump which at a level of 80 inches overflows and is carried by a two inch PVC pipe to the two 10 foot diameter HDPE treatment reactor vessels containing the ZVI. This design ensures that the ZVI treatment media remains submerged (saturated) at all times to minimize the effects of oxidation caused from exposure to the open atmosphere and wetting/drying cycles. The entire system is passive, i.e., gravity feed requiring no energy input. Figure 11 shows a plan layout view of the treatment system.

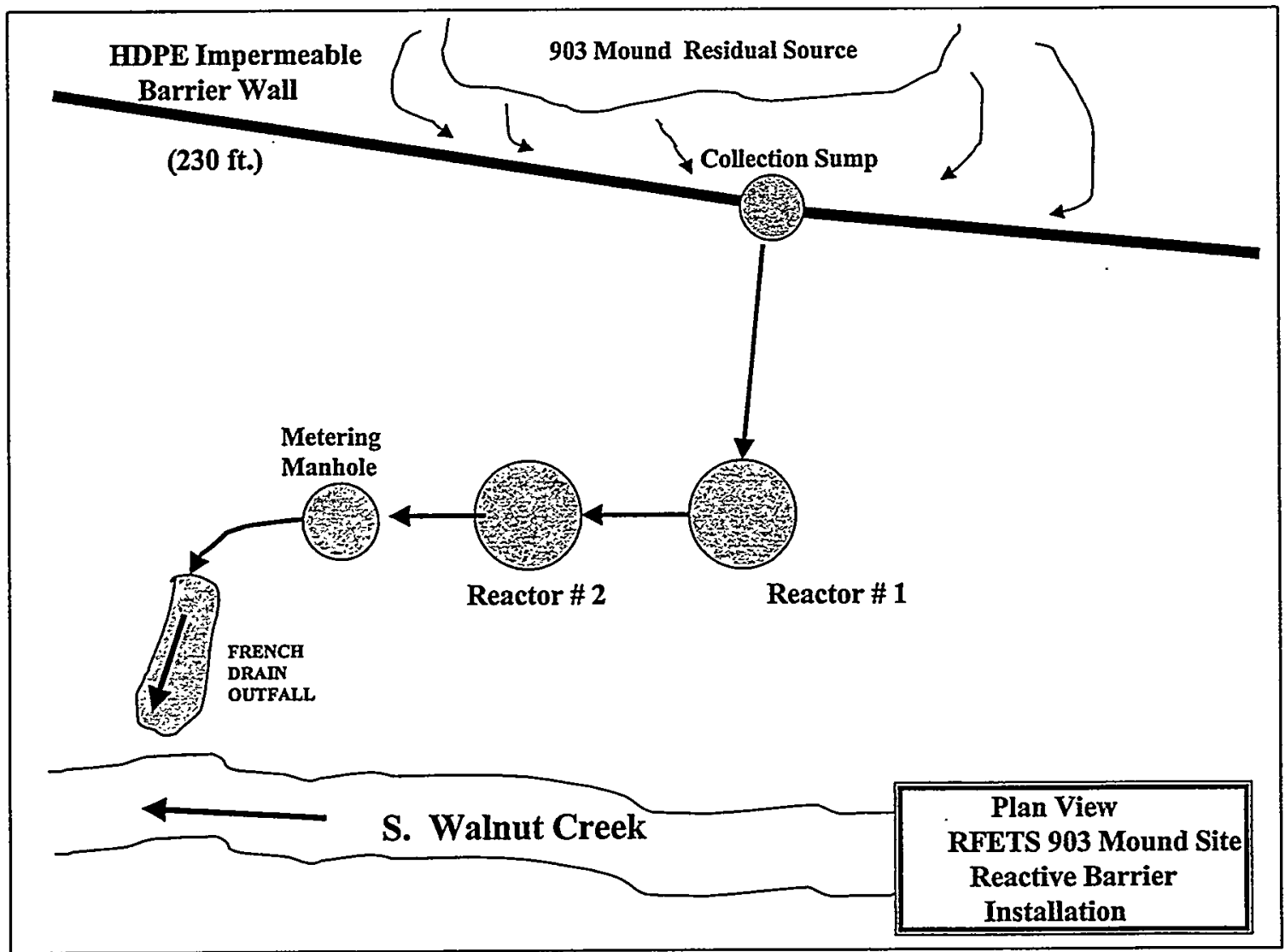

Figure 11. Schematic Plan View of 903 Mound Site Reactive Barrier Layout. 
Treated effluent from the reactor vessels is released into the stream at the bottom of the hill via a french drain outfall. Thus, the influents and effluents may be sampled directly. The reactor tanks have multiple sampling ports and top access that accommodate sampling. Figure 12 provides a profile view of the treatment system including sampling ports.

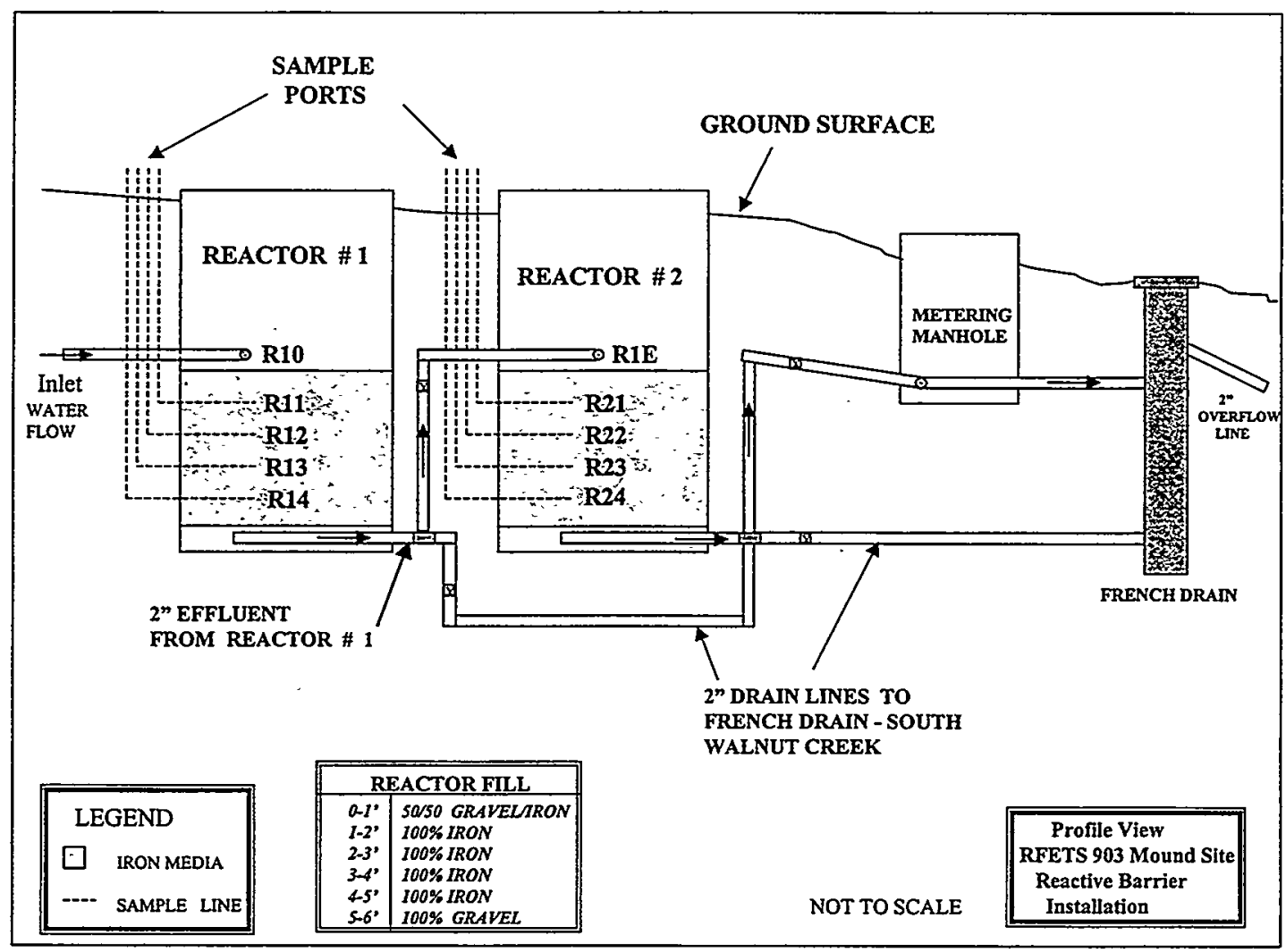

Figure 12. Schematic Profile View of 903 Mound Site Reactive Barrier Treatment System.

The reactors are cylindrical HDPE vessels with a 6 - $\mathrm{ft}$. by $6 \mathrm{ft}$. opening in the top. Each reactor has four sampling ports at 1-foot intervals (R11-R4 and R21-R24) along the water flowpath plus a port in the water above the media in each reactor (R10 and R1E). The reactors are at atmospheric pressure and are essentially open air. The reactors act as plug-flow vessels, i.e., water enters on top and pushes water out of the bottom; consequently the treatment media always has a minimum of six inches of water above the top layer. This design attempts to minimize surface oxidation by creating anoxic conditions. The vessels are plumbed in series and parallel so that either vessel or both can be operated in any possible sequence facilitating maintenance and/or change out of media. The composition inside each reactor initially was as follows: the bottom foot is $100 \%$ pea gravel; covered by four ft. of $100 \% \mathrm{ZVI}$ filings with sample ports every foot; topped off with a $50 \% / 50 \%$ - iron/pea gravel mixture. The bulk volume/reactor of media is 2311 gallons of which the calculated pore volume/reactor is approximately 809 gallons. Laboratory testing indicated this volume would treat 1000 pore volumes of the groundwater at expected contaminant levels. However, after approximately 200 pore volumes the top layer on Reactor No. 1 became crusted with calcium, magnesium and carbonaceous precipitates resulting in severe plugging of the flow. It was decided to remove the top layer (1 foot of 50\%/50\% iron/gravel) and replace it with a $90 \%$ gravel- $10 \% \mathrm{ZVI}$ mixture. 
The logic being that the precipitation effects would be minimized by having reducing conditions start deeper within the treatment media; thereby, minimizing the potential for oxidation.

Each reactor contains 25 tons of $8 X 50$ (U.S. Standard Sieve - No. $8=2.36 \mathrm{~mm}$ opening; No. 50 $=.300 \mathrm{~mm}$ opening) mesh ZVI provided by Connelly GPM, Inc. The system was designed so the iron media can be replaced in the future.

IT Corporation constructed the 903 Mound Site Reactive Barrier. The MSE report mentioned above documents details of the construction including as-built drawings and corresponding costs.

Figures $13,14,15,16$, and 17 show various construction stages.

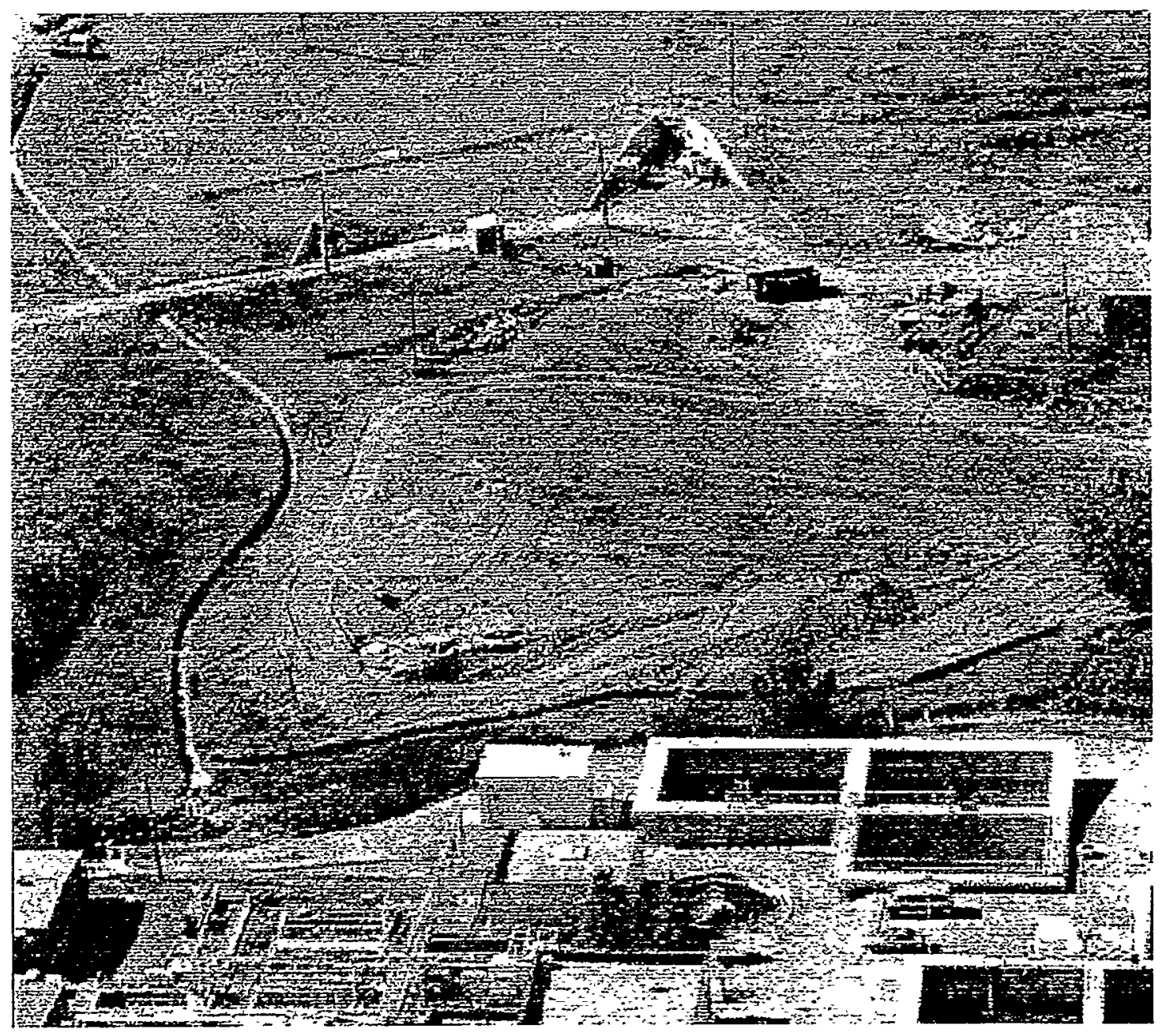

Figure 13. Plan view of 903 Mound Site. Early stages of grading. 


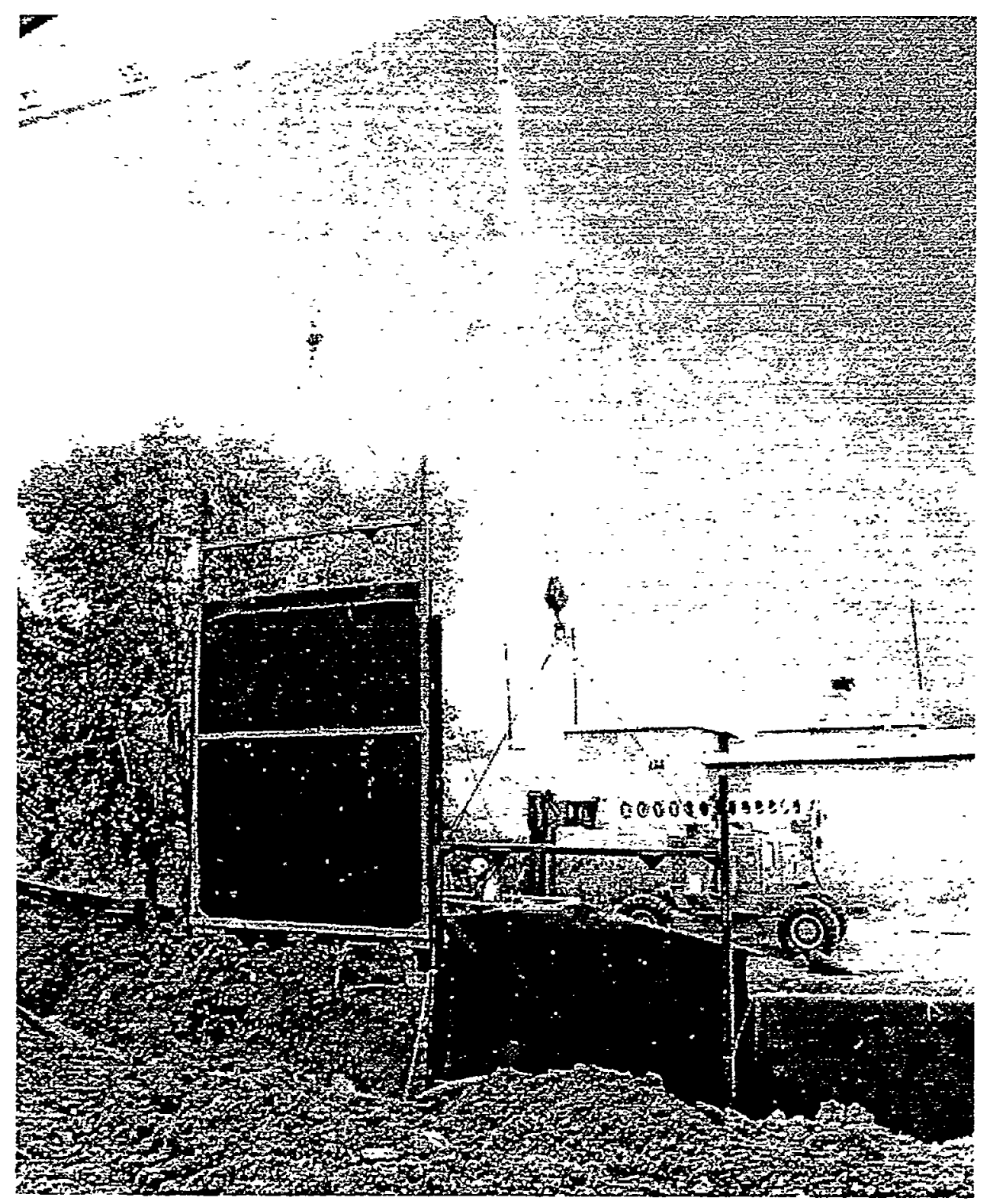

Figure 14. Installation of HDPE impermeable wall sections. Wall is composed of $10^{\prime}$ wide interlocking panels with a hydrophilic seal in the joints. 


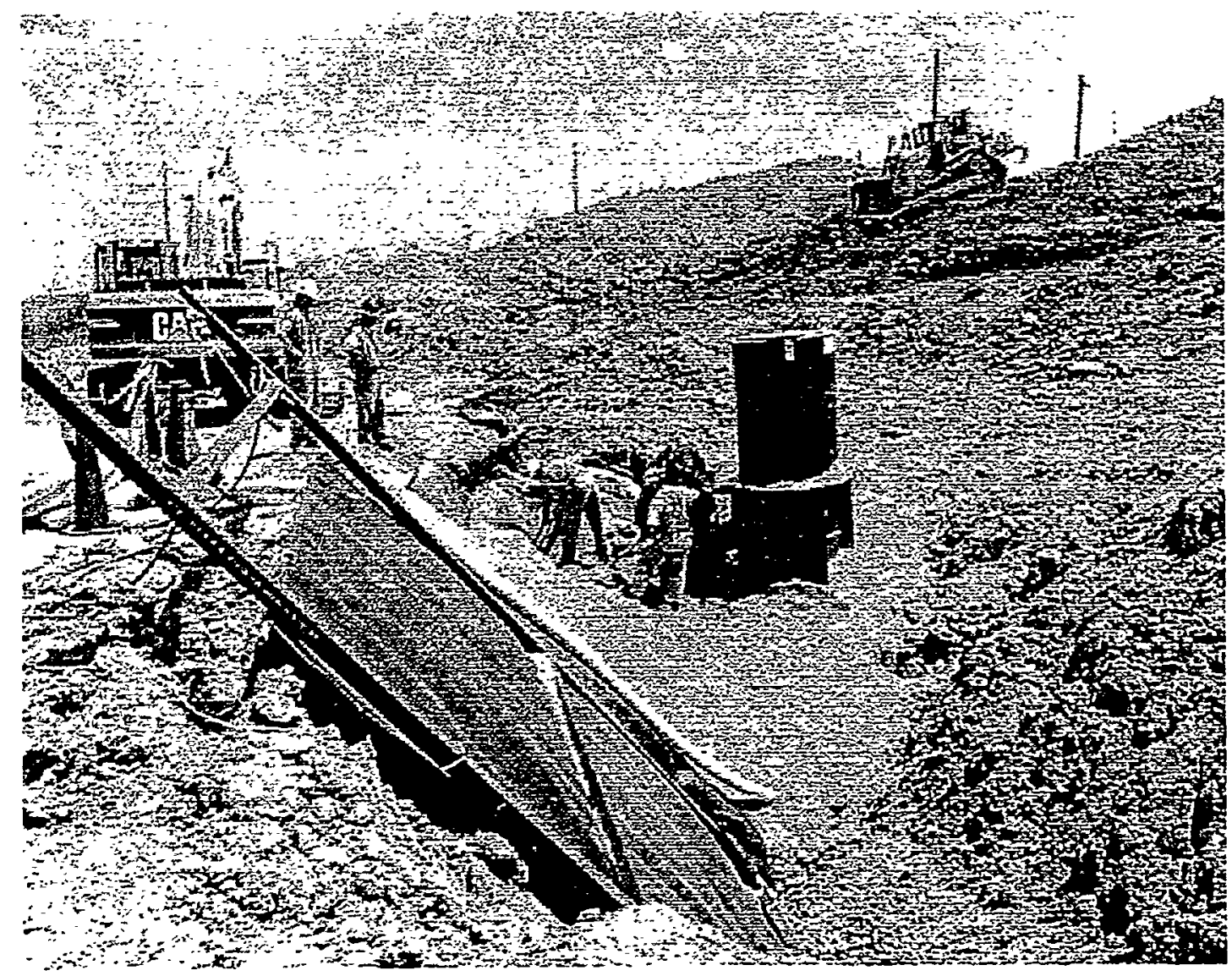

Figure 15. HDPE collection wall and sump. Low Cohesion (sloughing) soil conditions resulted in slanted installation of the HDPE in some areas of the wall. 


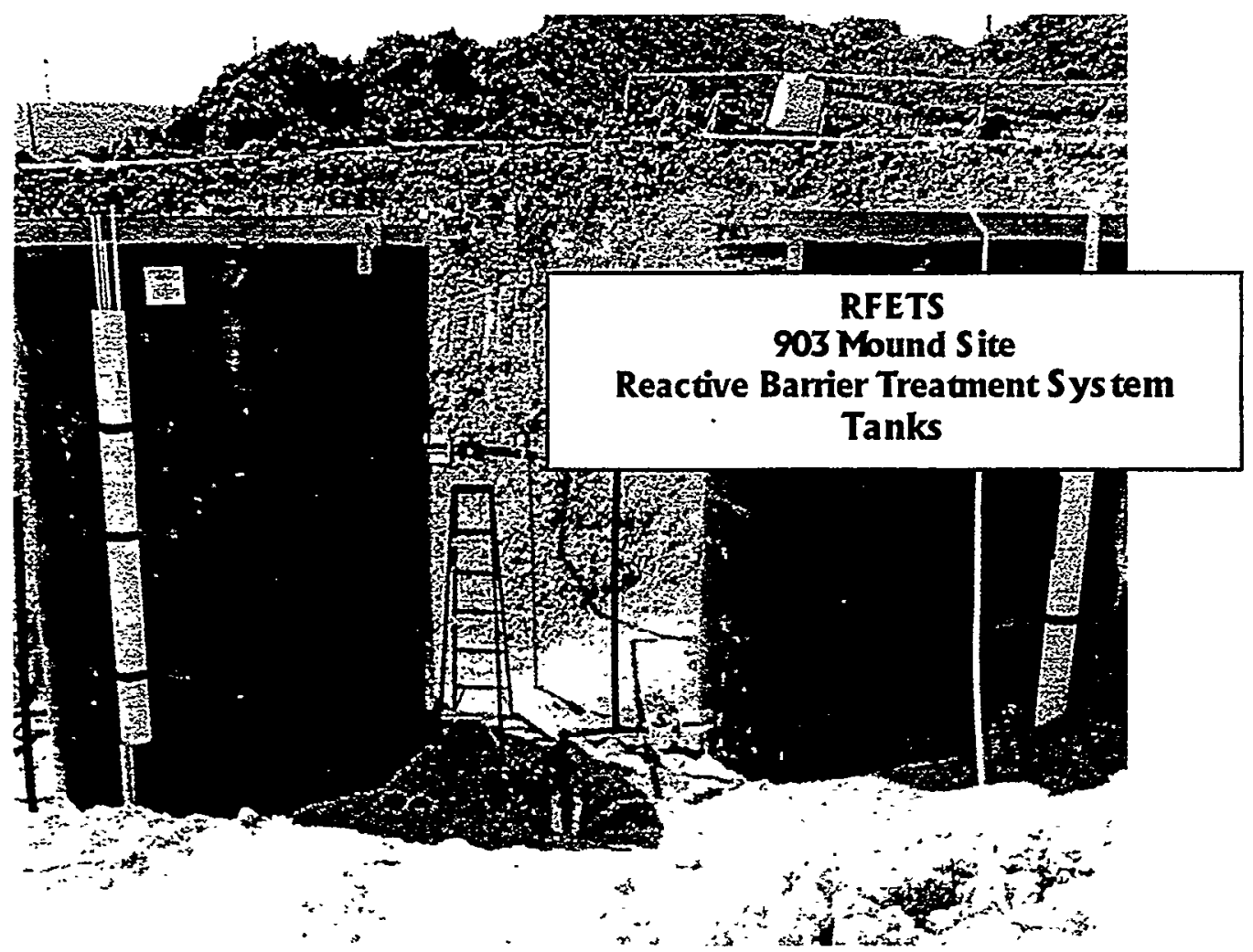

Figure 16. HDPE Reactor vessels prior to burial. Dimensions are 11'-6" tall $\times$ 9'-10" in diameter.

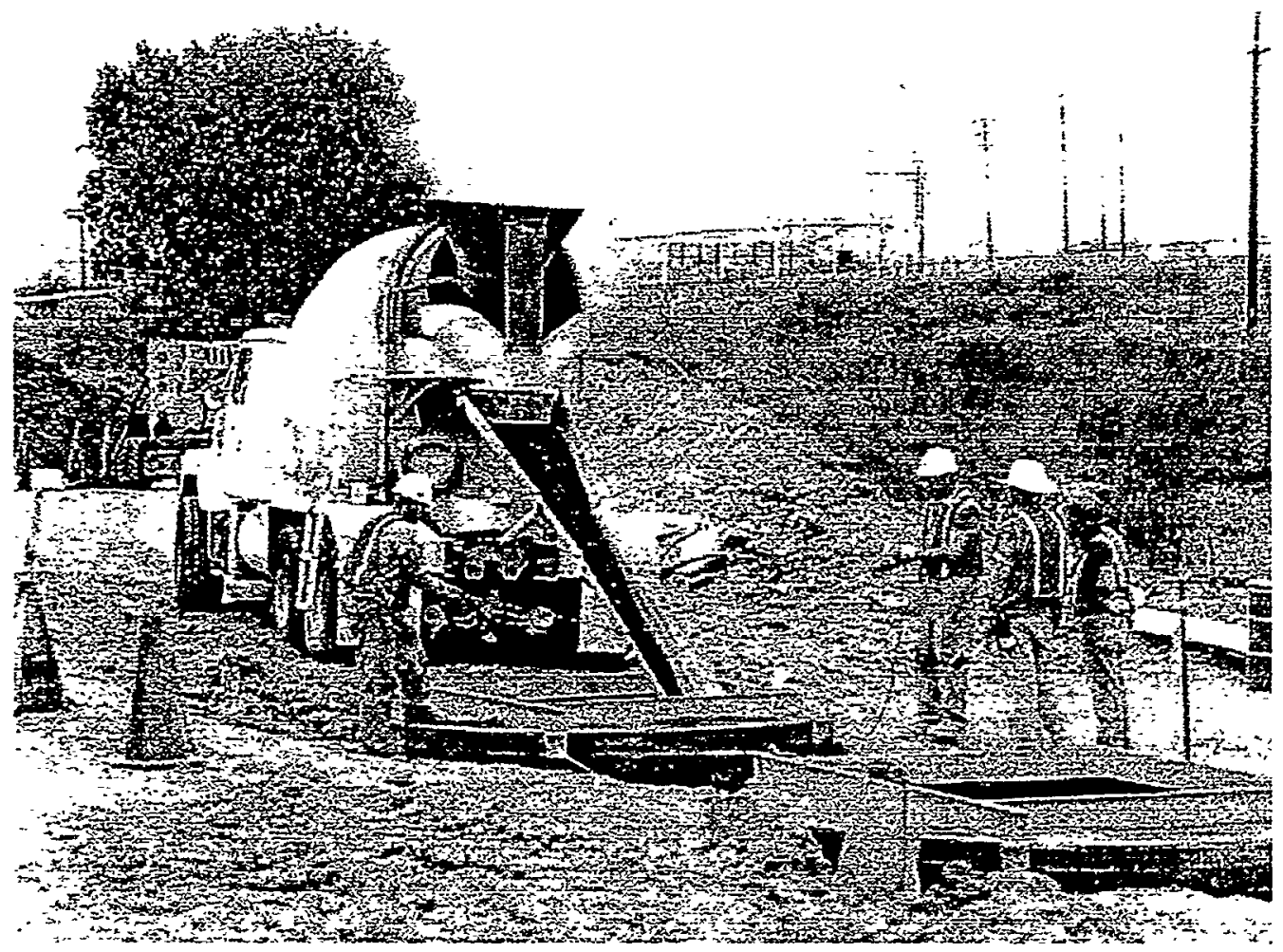

Figure 17. Reactor vessel loading. 
The loading sequence for the reactors was as follows:

1) the bottom foot was filled with pea gravel and the exit pipe imbedded midway in this section;

2) 4 feet of iron filings (ZVI) were loaded in one foot lifts with sample collection lines installed at each one foot increments; and

3) a mixture of $50 \%$ gravel and $50 \% \mathrm{ZVI}$ were placed as the top 1-foot layer.

The reactors are plumbed so that there is always a minimum of 6 inches of water above the top layer to minimize oxidation. Flow through the reactors is from top down; however, during initial startup the flow direction was reversed to remove any air during initial saturation.

\section{$\underline{\text { Results and Discussion }}$}

This treatment system functions to remove the COCs by creating a reducing groundwater environment. Typical signs of reducing conditions are an increase in $\mathrm{pH}$, and a decrease in redox conditions (Eh) as shown in Figures 18 and 19.

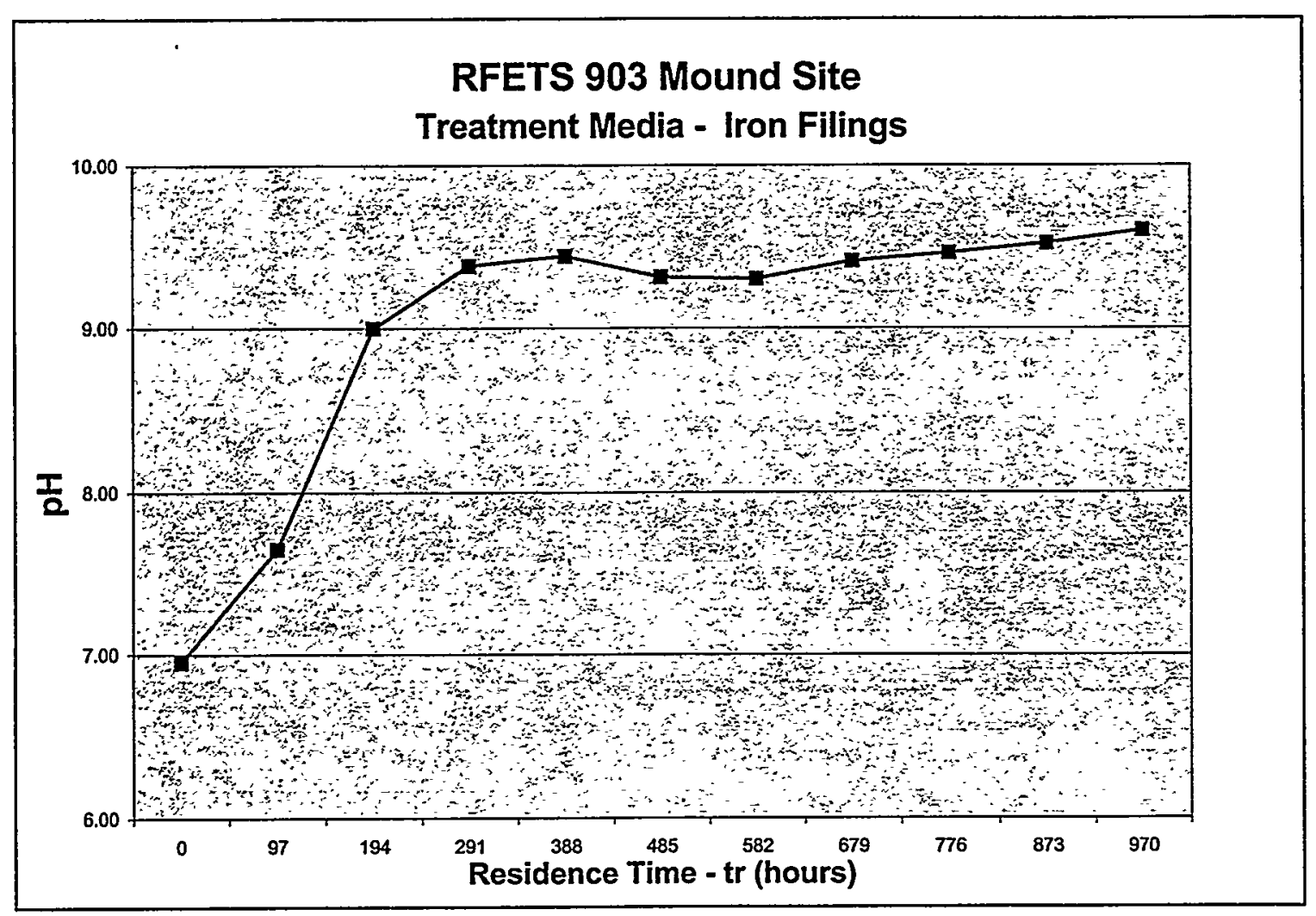

Figure 18. $\mathrm{pH}$ as a function of residence time (tr). 


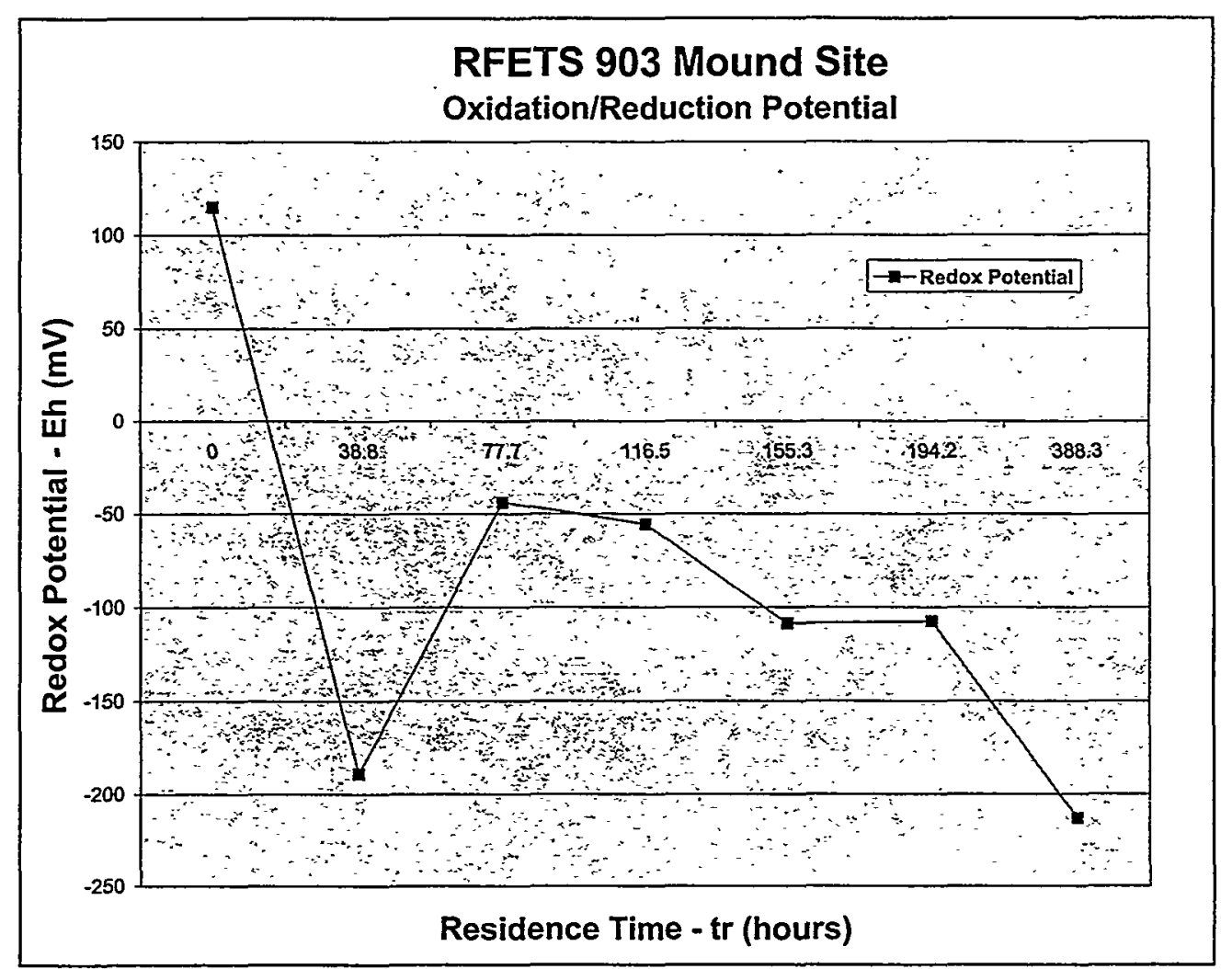

Figure 19. Eh as a function of residence time (tr).

The two figures are typical for all sampling events. The $\mathrm{pH}$ of the groundwater rises from near nuetral-7 to 9.5 as it flows through the system. The Eh also declines as expected; however it is not as textbook as the $\mathrm{pH}$ rise. Another very important parameter that is felt to be directly correlated to the performance longevity of a reactive barrier is the dissolved oxygen (DO). As the groundwater conditions become more reducing, i.e., less oxidizing, the DO should decline. 


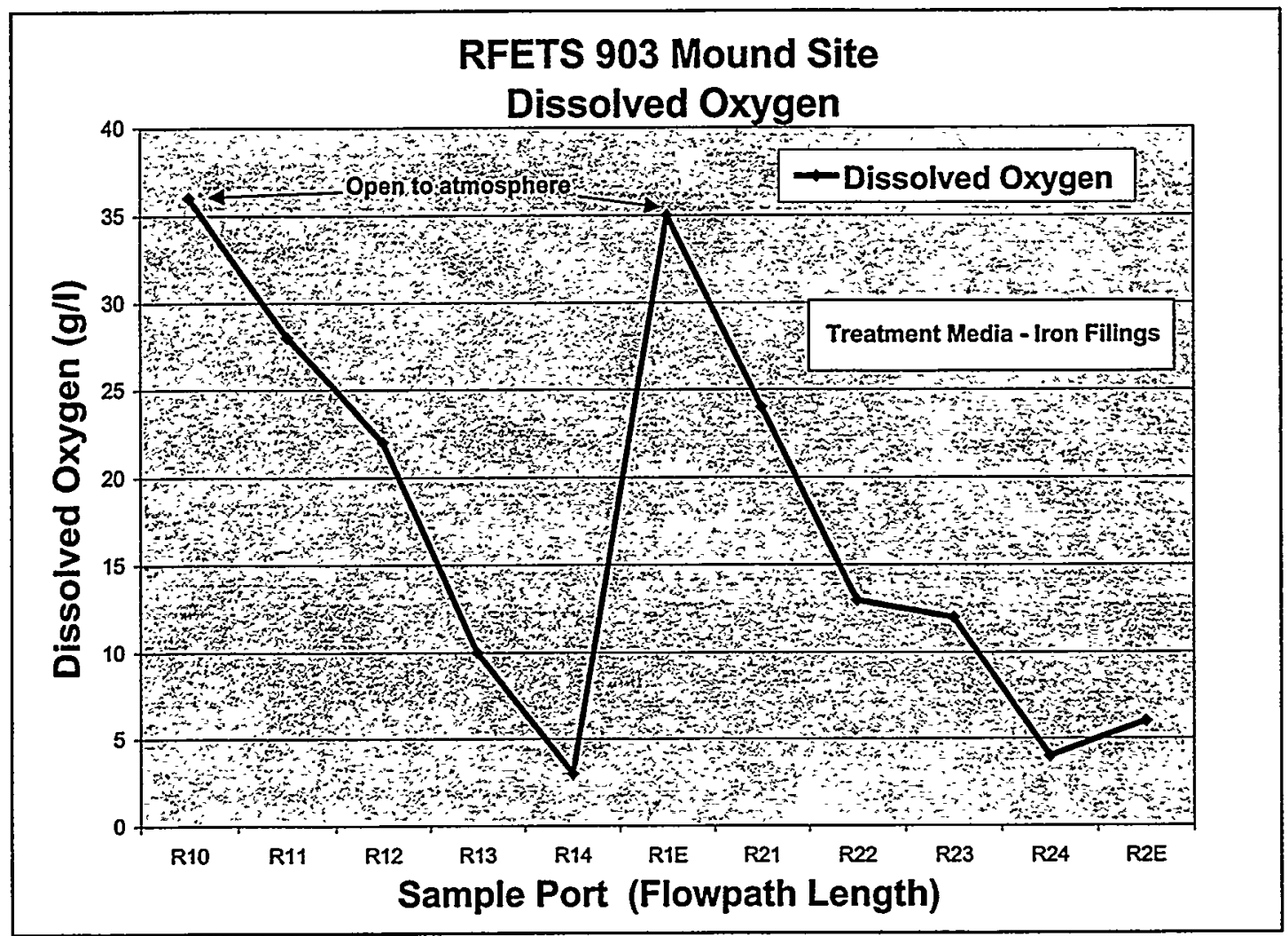

Figure 20. Dissolved Oxygen (DO) as a function of flowpath length.

Figure 20 charts the DO along the flowpath of the groundwater. The DO starts above $35 \mathrm{~g} / \mathrm{L}$ at R10 which is open to the atmosphere, then falls to near zero at R14 which is the bottom of Reactor \#1, then the water is routed to the top of Reactor \#2. As expected the DO rises to $35 \mathrm{~g} / \mathrm{L}$ because the water is exposed to atmospheric (oxygenated) conditions again, then DO declines as anoxic conditions persist through Reactor \#2.

The treatment system is designed to accommodate flow rates ranging from $0.1 \mathrm{gpm}$ to $2 \mathrm{gpm}$. To date, the flowrate has fluctuated from 0.04 to $1.5 \mathrm{gpm}$, often times slower than expected. The cumulative volume treated is 572,567 gallons through September 2000; this equates to 354 pore volumes (considering both reactor vessels). Recently (summer of 2000) the flowrate ranged from 0.5 to $1.3 \mathrm{gpm}$, showing signs of a long anticipated equilibration. As a result of the low flow rates, the tr values often appeared very high. This is because the system operates as a plug flow reactor, i.e., untreated water must enter the system to flush the treated water from the system. Each tr value corresponds to a sample port. Refer to Figure 12 for the location of sampling ports, noting the sampling flowpath starts at R10 and ends at R2E.

Figure 21, 22, 23, and 24 show removal rates and RFETS Action Levels for the organic COCs. All the COCs are removed to well below the Action Levels prior to release; however, the TCE and $\mathrm{PCE}$ removal is slower than expected. 


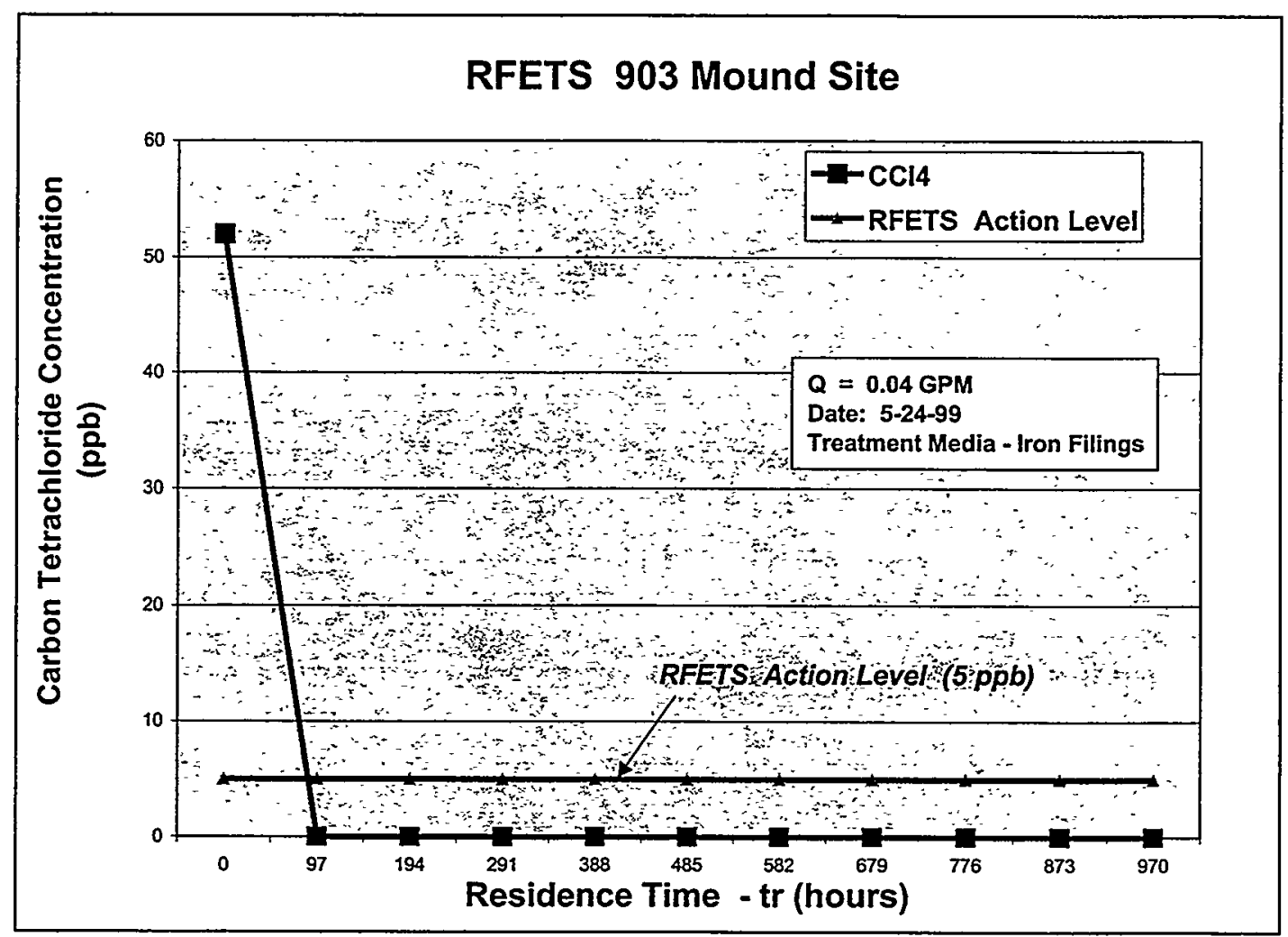

Figure 21. Carbon Tetrachloride Removal.

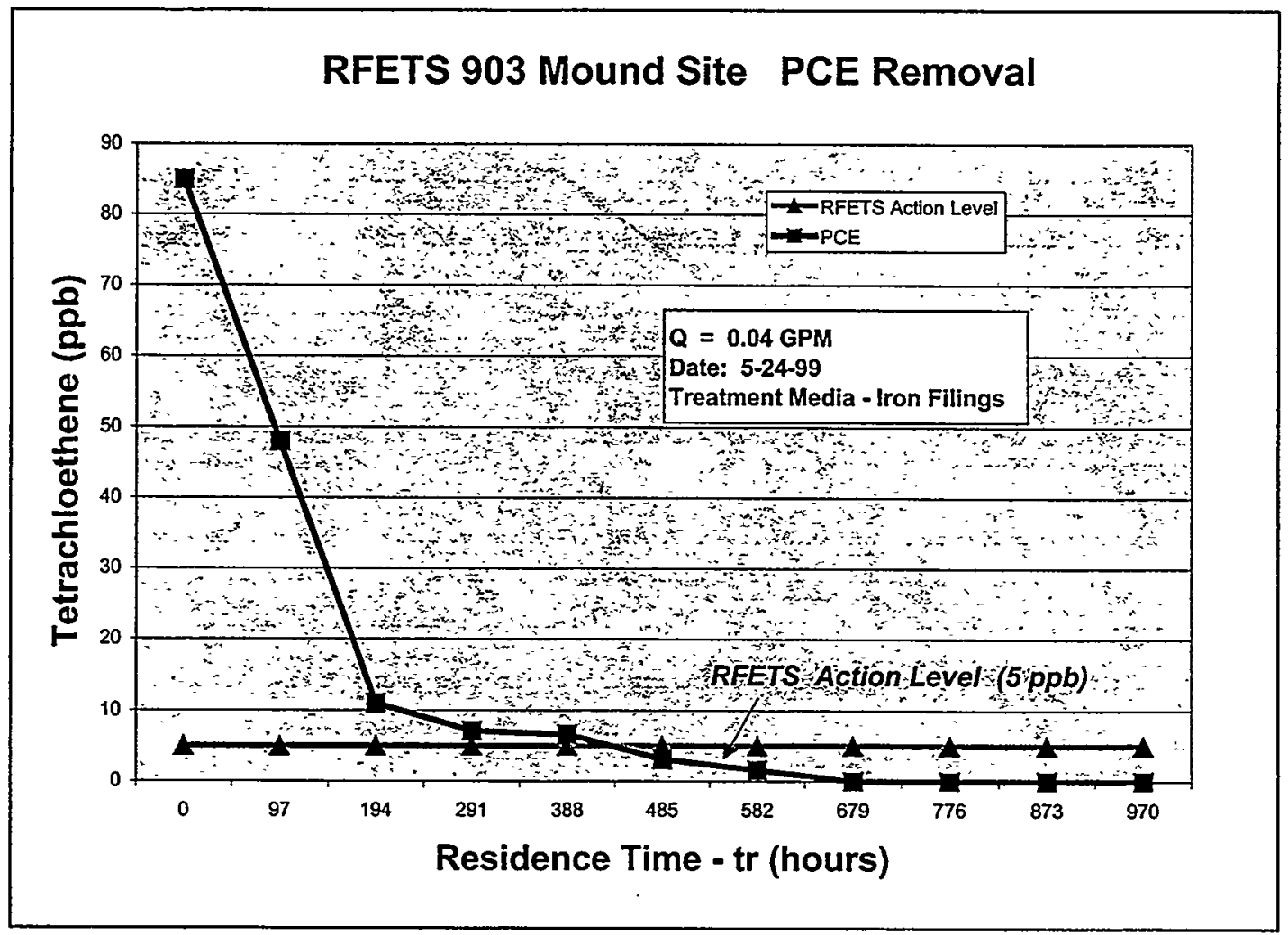

Figure 22. Tetrachloroethene Removal. 


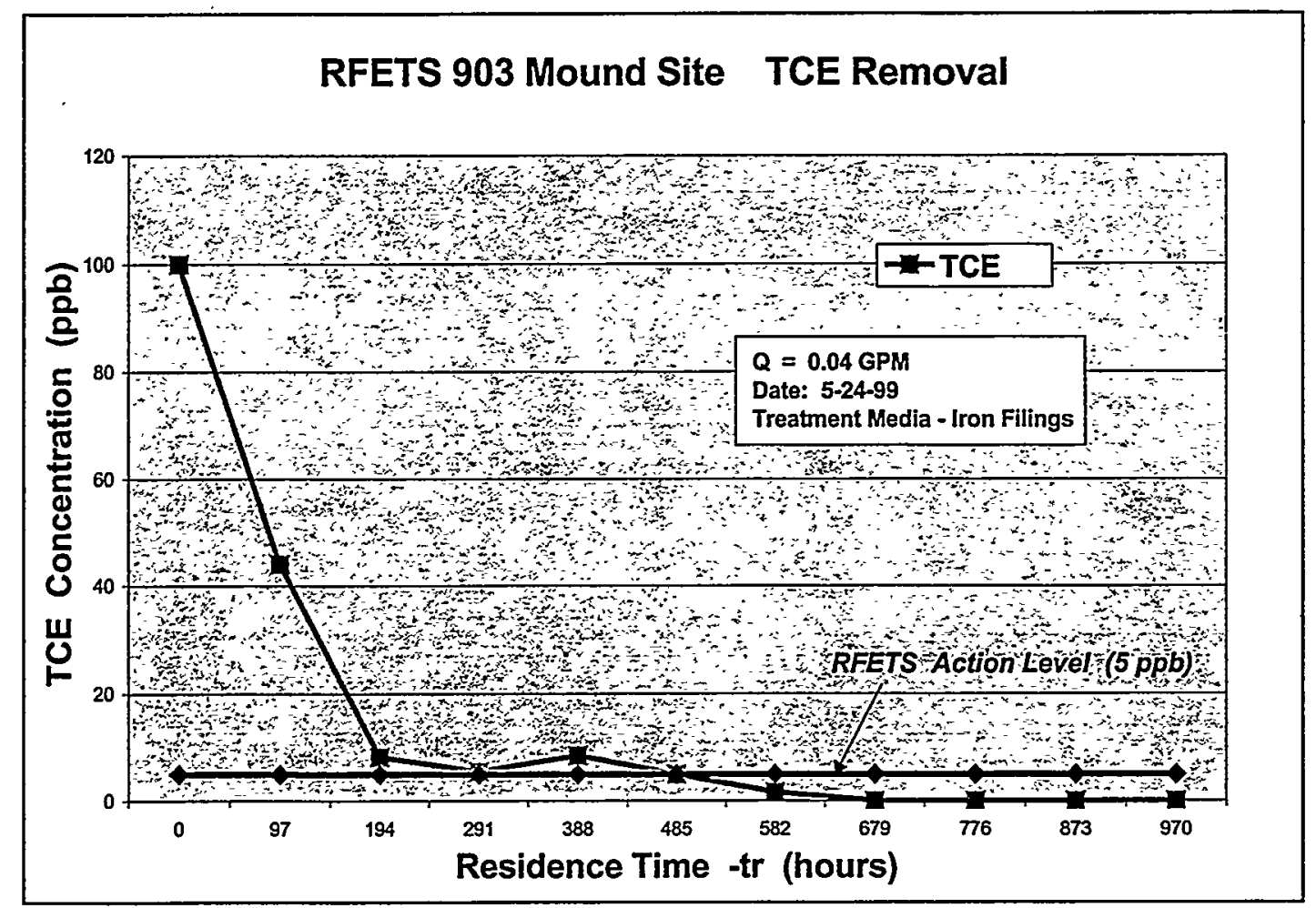

Figure 23. Trichloroethene Removal.

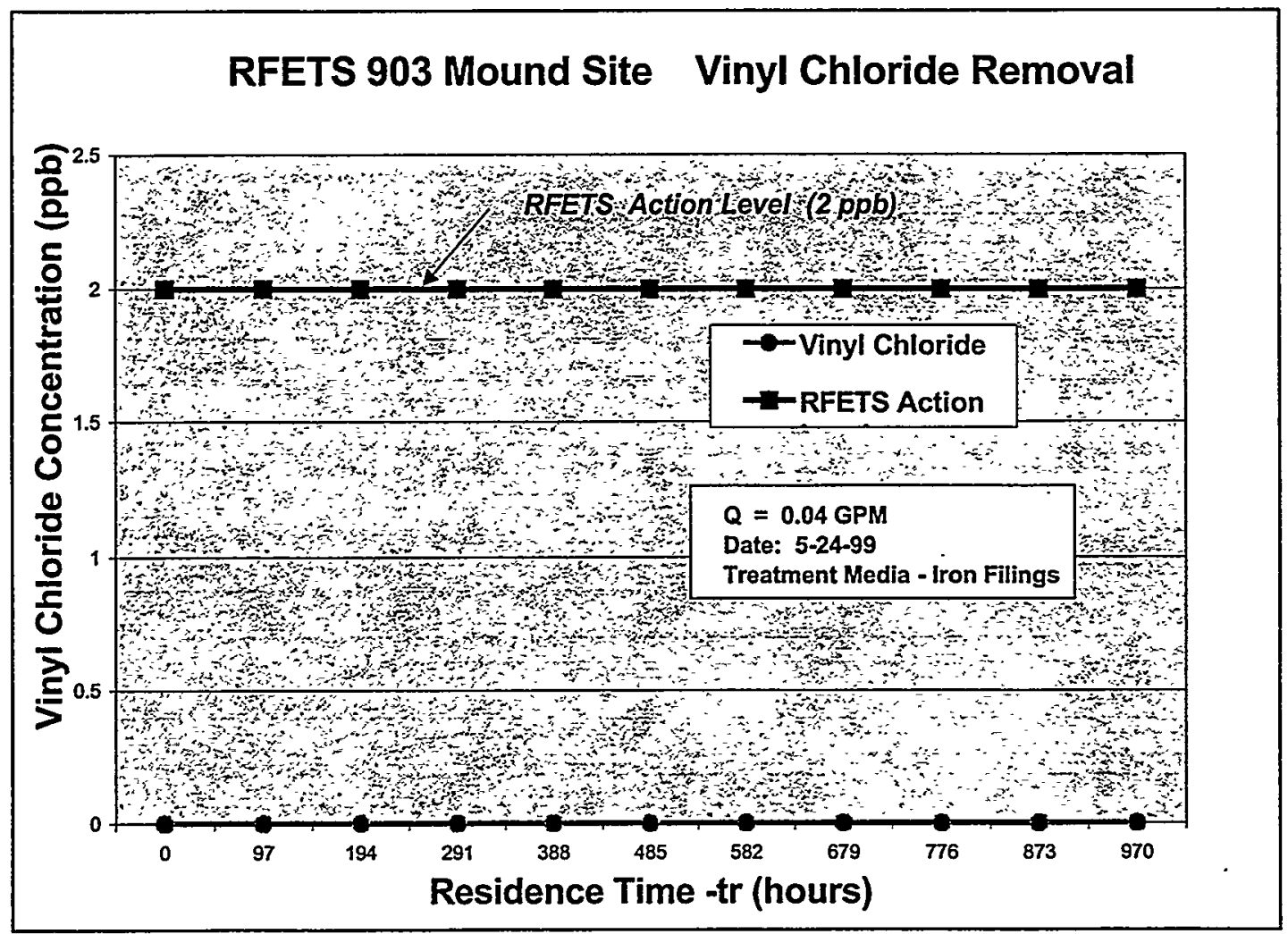

Figure 24. Vinyl Chloride Removal 
Figures 25 and 26 show the radionuclide removal rates. Uranium is completely removed by the first sample port R11, which is the equivalent of passing one foot of the ZVI treatment media. Americium is essentially non-detectable. Finally, Figure 27 shows the iron and manganese levels. Iron is released, i.e., becomes mobile, initially within the first two feet of the reactor but is not present beyond the second sampling port R12. The presence of manganese, which is often released from the ZVI is negligible.

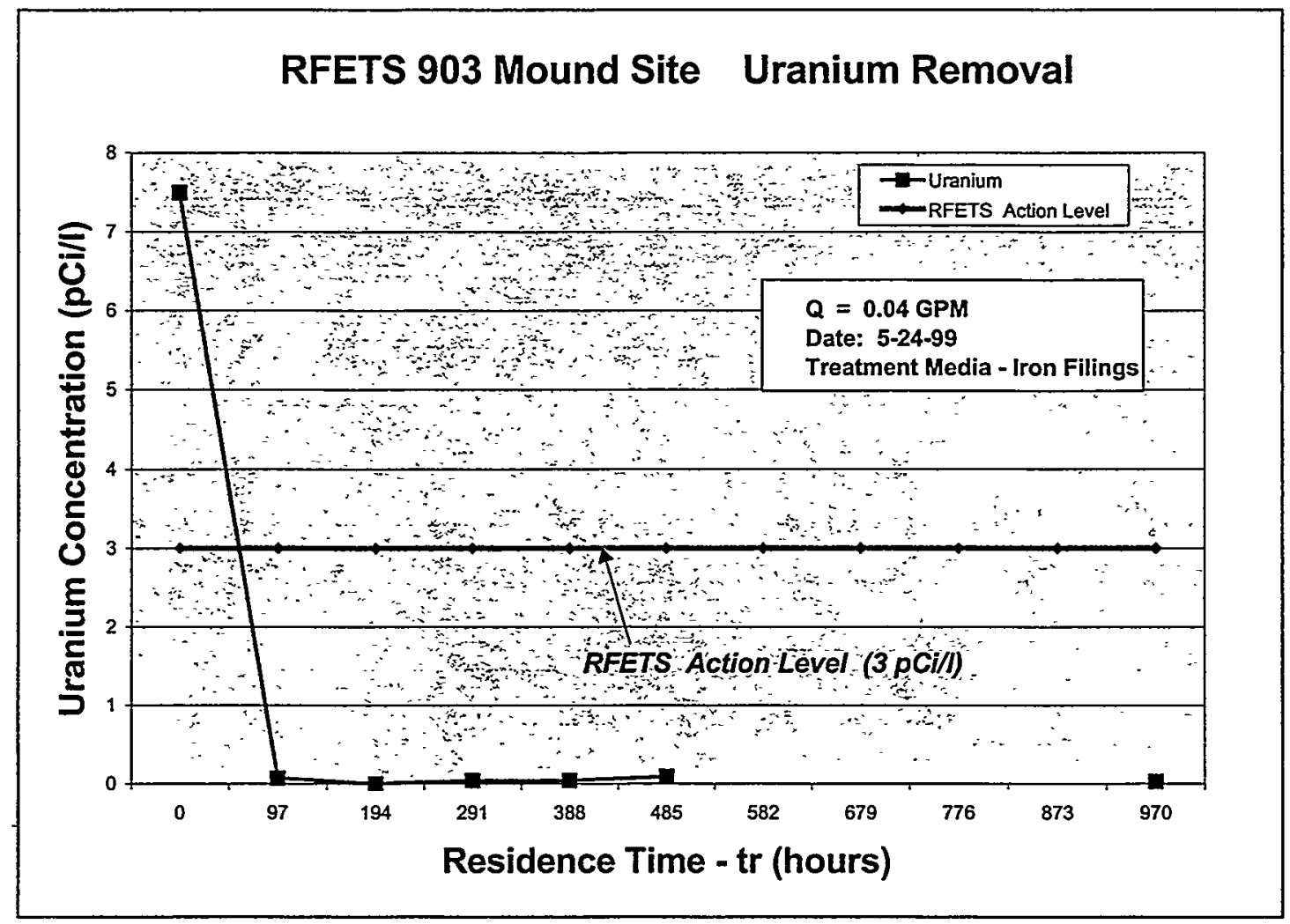

Figure 25. Uranium Removal. 


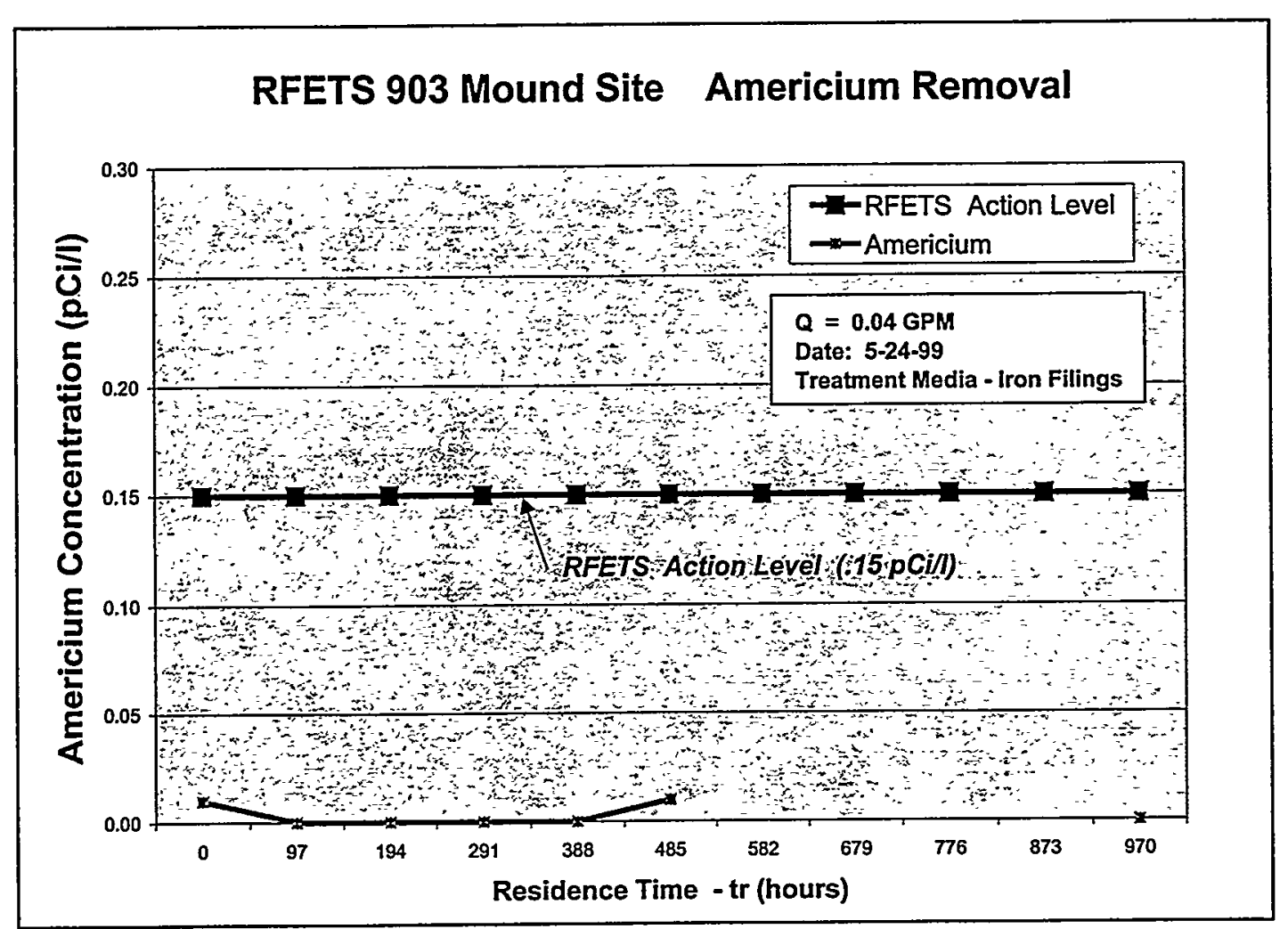

Figure 26. Americium Removal.

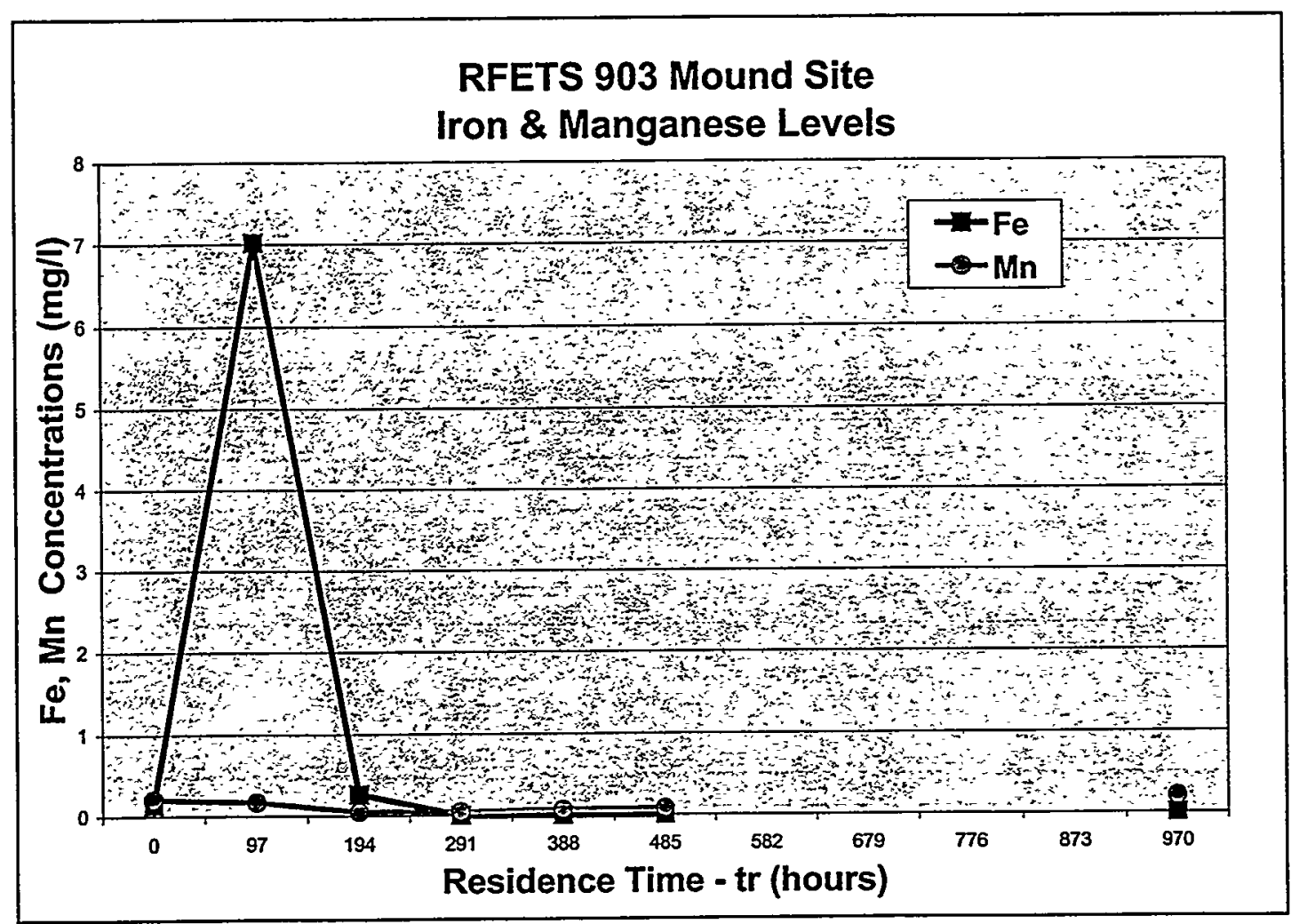

Figure 27. Iron and Manganese Removal. 


\section{Conclusions}

The 903 Mound Site Plume reactive barrier treatment system has and continues to remove the COCs to below RFETS Action Levels within the first couple of feet of the reactive media bed in Reactor No. 1. The removal rates, and required residence times align very well with the laboratory and pilot field column studies. This is important for the future of reactive barrier technology. Concurrence between laboratory and pilot scale data with full scale field data lends confidence to a design engineer that the parameters developed early on from lab and pilot scale experiments will provide an accurate predictor of full scale results. This knowledge can be translated into cost savings by allowing a more precise design factor of safety (F.S.). To date reactor designs have used excessive F.S., and consequently overdesigned treatment zones, because of lack of confidence in the lab and pilot derived parameters. If this technology is to maximize the economic advantages to baseline methods, a more reasonable F.S. needs to be used.

\section{COST DATA SUMMARY}

MSE reported cost information previously under TTP No. FT18SS46, Permeable Reactive Barriers - A Cost Evaluation with Summary Information on Barriers Installed at Oak Ridge and Rocky Flats. This summary will focus on the Rocky Flats 903 Mounds Site cost data.

\section{Construction Costs}

Initially RFETS collected the residual contaminated groundwater leaching from the 903 Mound Site at SW 059, a collection gallery draining into a seep. This water was pumped to a holding tank and periodically treated at the on-site treatment facility (CTWF). RFETS is planning on decommissioning the water treatment facility in 2006; consequently, a long-term (30 years) replacement solution was needed. Three remedial options were considered:

1. continue present operating mode;

2. construct an impermeable barrier wall to direct contaminated groundwater to a collection point where it would be periodically trucked to the on site treatment facility; and

3. construct an impermeable wall and treatment system that was passive in nature, i.e., no energy input required, that would treat the contaminated groundwater in situ.

Option 3 was chosen primarily because the water treatment facility will be decommissioned in 2006 and subsequently the entire facility will be decommissioned shortly thereafter. The three remedial alternatives are evaluated in detail in draft decision document by Rocky Mountain Remedial Services (RMRS, 1997). The document discusses costs for the three options. In addition, the draft states that the Mound Site plume will reach drainage completion within 30 years; therefore, a barrier would only need to intercept water for half of that time - 15 years. The document compared life cycle cost of the three options.

Option 1 Continue present operations (this option will not meet RFCA requirements because not all contaminated waters from the plume are being collected) 
Present cost to collect and treat waters, $\$ 1.50 /$ gallon

Present flow rate, $0.05 \mathrm{gpm}$ or $28,000 \mathrm{gal} /$ year

Yearly operational cost, $\$ 42,000 \quad$ NPV for 15 years $@ 3.7 \% \cdot=\$ 477,000$

Replacement cost of CWFT in year 7, $\$ 100,000 \mathrm{NPV}$ for year $7 @ 3.7 \%=\$ 78,000$

NPV of costs

$\$ 555,000$

Option 2 Build deflection barrier, truck water to CWFT

Installation cost of barrier $\$ 200,000$

Present cost to collect and treat waters, $\$ 1.50 /$ gallon

Estimated design flow rate, 0.1 to $2.0 \mathrm{gpm}$, use 1.0 or $500,000 \mathrm{gal} / \mathrm{year}$

Yearly operational cost, $\$ 750,000 \quad$ NPV for 15 years @ 3.7\% $=\$ 8,516,000$

Replacement cost of CWFT in year 7, \$100,000NPV for year $7 @ 3.7 \%=\frac{\$ 78,000}{\$ 8,800,000}$

NPV of costs

$\$ 8,800,000$

Option 3 Build reactive barrier system for in situ remediation (Using the final cost of the actual installed Mound Site treatment system)

Installation cost of barrier

Replenish $25 \%$ of reactive media in

Year 5, $\$ 50,000$

Replenish $25 \%$ of reactive media in

Year $10, \$ 50,000$

NPV of costs

$\$ 600,00$

NPV for year $5 @ 3.7 \%=\quad=\quad \$ 42,000$

$\mathrm{NPV}$ for year $10 @ 3.7 \%=\frac{\$ 35,000}{\$ 677,000}$

(RMRS, 1997)

The reactive barrier costs (Option 3) are separated into four distinct components: (1) treatability studies; (2) design and engineering; (3) construction; and (4) operation \& maintenance (O\&M). It is very difficult to provide a meaningful assessment of cost components 1 and 2 as in a typical cost study of a construction-based project because this is an EM-50 project of an experimental nature. However, parts 3 and 4 are directly pertinent to EM-40, DoD, and others considering this technology for their own site(s).

\begin{tabular}{|c|c|c|}
\hline Activity & Cost $(\$)$ & Cost $/ \mathrm{ft}^{2}$ Basis, $4500 \mathrm{ft}^{2}\left(\$ / \mathrm{ft}^{2}\right)$ \\
\hline $\begin{array}{l}\text { Preconstruction activities, } \\
\text { training, etc. }\end{array}$ & 29,000 & 6.44 \\
\hline $\begin{array}{l}\text { Equipment staging, site } \\
\text { preparation }\end{array}$ & 65,000 & 14.44 \\
\hline Excavate and set reactor tanks & 42,300 & 9.40 \\
\hline $\begin{array}{l}\text { Excavate, install barrier } \\
\text { wings, collection sump, } \\
\text { piping, plumbing, load } \\
\text { reactors. }\end{array}$ & 442,700 & 98.38 \\
\hline Site Cleanup & 21,000 & 4.67 \\
\hline TOTALS & 600,000 & 133.00 \\
\hline
\end{tabular}


* costs are based on $4500 \mathrm{ft}^{2}$ cross-sectional barrier wall

The baseline technology for the 903 Mound Site Plume is "pump-and-treat". The estimated costs for this cleanup method is as follows:

\section{Pump and Treat System}

Installation cost

Yearly operational cost, $\$ 180,000$

Yearly maintenance cost, $\$ 30,000$

NPV of costs
$\$ 600,000$

NPV for 15 years @ 3.7\% = $\$ 2,044.000$

NPV for 15 years @3.7\% $\equiv \frac{\$ 341,000}{\$ 3,000,000}$

(RMRS, 1997)

The estimated NPV cost for the baseline - pump and treat is approximately 5 times more than the actual reactive barrier costs (Option 3). Option 1 is less expensive than option 3; however, it does not meet regulatory requirements and therefore could not be used. Options 2 is 13 times more expensive than Option 3.

Project Return on Investment (ROI)

ROI @NPV = cost savings/investment cost

Cost savings $=3,000,000-677,000=2,323,000$

ROI $=2,323,000 / 677,000=3.43$ 


\section{REFERENCES}

Gillham, R.W., S.F. O'Hannesin, M.S. Odziemkowski, R.A. Garcia-Delgado, R.M. Focht, and W.H. Matulewicz. 1997. Enhanced Degradation of VOCs: Laboratory and Pilot-Scale Field Demonstration. Presented at the 1997 International Containment Technology Conference, St Petersburg, FL, February 9-12.

MSE Technology Applications, Inc., Permeable Reactive Barriers - Cost Evaluation with Summary Information on Barriers Installed at Oak Ridge and Rocky Flats. Prepared for the Department of Energy and FETC Energy Technology Center.

MSE Technology Applications, Inc., Reactive Barrier System Demonstration Report Rocky Flats Environmental Technology Site, Mound Site Plume, Western Environmental Technology Office, March 1999.

Rocky Mountain Remediation Services, L.L.C., A Kaiser-Hill Company, Draft Mound Site Plume Decision Document, RF/RMRS-97-024, March 1991, revised October 1994, revised August 20, 1997.

U.S. Army Corps of Engineers, Omaha District, "Specifications Final Design, Mound Site Plume Treatment System", Rocky Flats, Colorado, August, 1997. 


\section{APPENDIX A}

A-1 


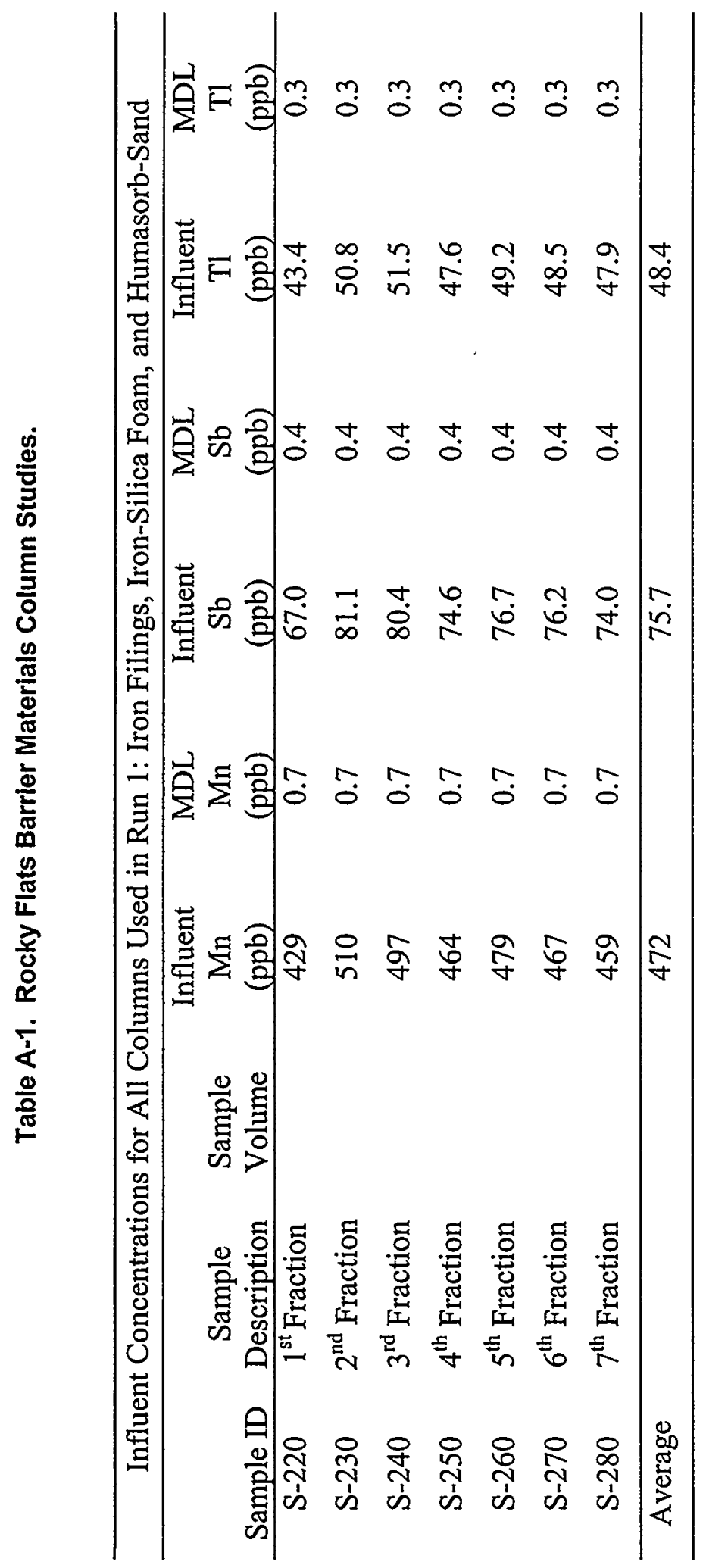


Table A-2. Rocky Flats Barrier Materials Column Studies.

Effluents from the Connelly Iron Filings Column, Run 1

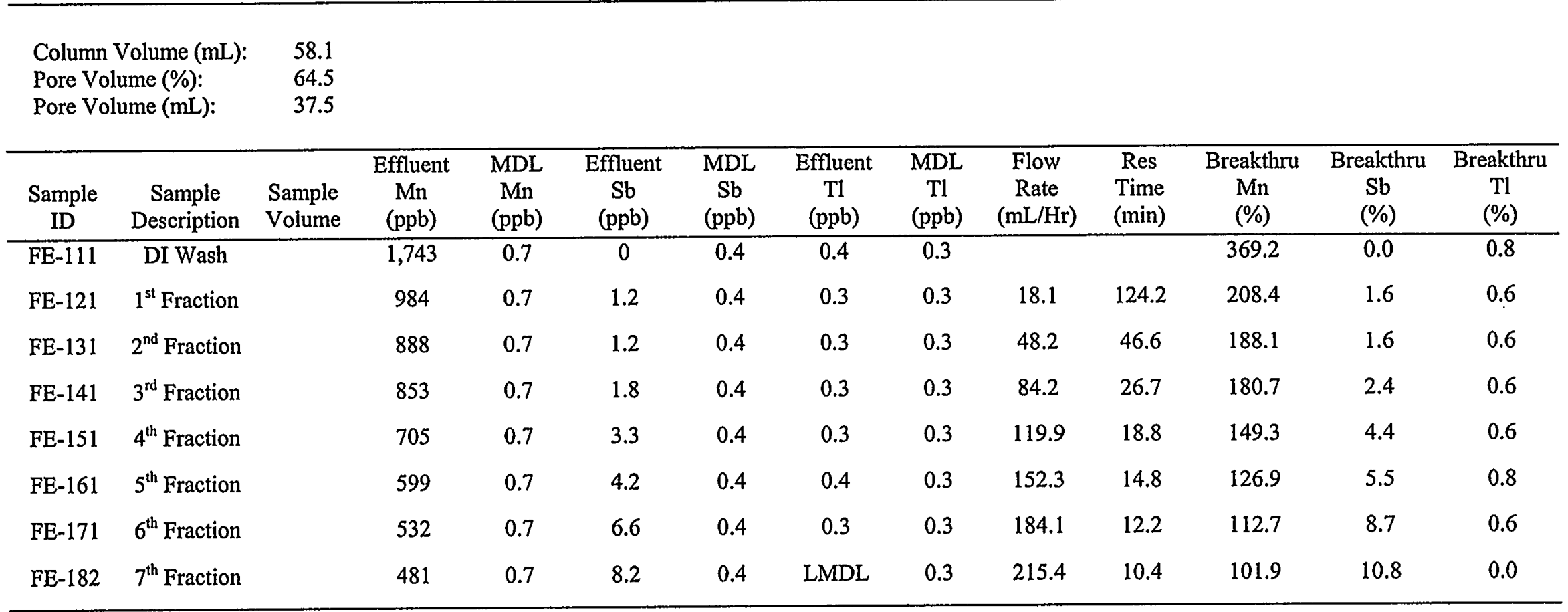

$\mathrm{LMDL}=$ lower than the material detection limit 
Table A-3. Rocky Flats Barrier Materials Column Studies.

Effluents from the Iron-Silica Foam Column, Run 1

Column Volume (mL): $\quad 58.52$

Pore Volume (\%): $\quad 69.2$

Pore Volume (mL): $\quad 40.5$

\begin{tabular}{|c|c|c|c|c|c|c|c|c|c|c|c|c|c|}
\hline Sample ID & $\begin{array}{c}\text { Sample } \\
\text { Description }\end{array}$ & $\begin{array}{c}\text { Sample } \\
\text { Volume } \\
\text {. }\end{array}$ & $\begin{array}{c}\text { Effluent } \\
\text { Mn } \\
\text { (ppb) }\end{array}$ & $\begin{array}{c}\text { MDL } \\
\text { Mn } \\
(\mathrm{ppb})\end{array}$ & $\begin{array}{c}\text { Effluent } \\
\text { Sb } \\
\text { (ppb) }\end{array}$ & $\begin{array}{c}\mathrm{MDL} \\
\mathrm{Sb} \\
(\mathrm{ppb})\end{array}$ & $\begin{array}{c}\text { Effluent } \\
\text { Tl } \\
\text { (ppb) }\end{array}$ & $\begin{array}{c}\mathrm{MDL} \\
\mathrm{Tl} \\
(\mathrm{ppb})\end{array}$ & $\begin{array}{c}\text { Flow } \\
\text { Rate } \\
\text { (mL/Hr) }\end{array}$ & $\begin{array}{c}\text { Res } \\
\text { Time } \\
\text { (min) }\end{array}$ & $\begin{array}{c}\text { Breakthru } \\
\text { Mn } \\
(\%)\end{array}$ & $\begin{array}{c}\text { Breakthru } \\
\mathrm{Sb} \\
(\%)\end{array}$ & $\begin{array}{c}\text { Breakthru } \\
\mathrm{Tl} \\
(\%)\end{array}$ \\
\hline FESI- 112 & DI Wash & & 158 & 0.7 & 2.60 & 0.4 & 0.3 & 0.3 & & & 33.5 & 3.4 & 0.6 \\
\hline FESI-122 & $1^{\text {st }}$ Fraction & & 2,626 & 0.7 & 16.50 & 0.4 & 0.3 & 0.3 & 18.3 & 122.9 & 556.2 & 21.8 & 0.6 \\
\hline FESI-132 & $2^{\text {nd }}$ Fraction & & 1,138 & 0.7 & 21.10 & 0.4 & 0.4 & 0.3 & 47.8 & 47.0 & 241.0 & 27.9 & 0.8 \\
\hline FESI-142 & $3^{\text {rd }}$ Fraction & & 975 & 0.7 & 24.70 & 0.4 & 0.3 & 0.3 & 84.2 & 26.7 & 206.5 & 32.6 & 0.6 \\
\hline FESI-152 & $4^{\text {th }}$ Fraction & & 772 & 0.7 & 27.20 & 0.4 & 0.5 & 0.3 & 119.9 & 18.8 & 163.5 & 35.9 & 1.0 \\
\hline FESI-162 & $5^{\text {th }}$ Fraction & & 677 & 0.7 & 27.60 & 0.4 & 1.4 & 0.3 & 152.3 & 14.8 & 143.4 & 36.5 & 2.9 \\
\hline FESI-182 & $7^{\text {th }}$ Fraction & & 563 & 0.7 & 28.10 & 0.4 & 4.3 & 0.3 & 215.2 & 10.4 & 119.2 & 37.1 & 8.9 \\
\hline
\end{tabular}

Note: the $6^{\text {th }}$ fraction gave spurious results and was not included. 
Table A-4. Rocky Flats Barrier Materials Column Studies.

\section{Effluents from Humasorb-Sand Column, Run 1}

Column Volume $(\mathrm{mL}): \quad 69.82$

Pore Volume (\%): $\quad 42.2$

Pore Volume (mL): $\quad 29.5$

\begin{tabular}{|c|c|c|c|c|c|c|c|c|c|c|c|c|c|}
\hline Sample ID & $\begin{array}{c}\text { Sample } \\
\text { Description }\end{array}$ & $\begin{array}{l}\text { Sample } \\
\text { Volume }\end{array}$ & $\begin{array}{c}\text { Effluent } \\
\mathrm{Mn} \\
(\mathrm{ppb})\end{array}$ & $\begin{array}{c}\text { MDL } \\
\mathrm{Mn} \\
(\mathrm{ppb})\end{array}$ & $\begin{array}{c}\text { Effluent } \\
\mathrm{Sb} \\
(\mathrm{ppb})\end{array}$ & $\begin{array}{c}\mathrm{MDL} \\
\mathrm{Sb} \\
(\mathrm{ppb})\end{array}$ & $\begin{array}{c}\text { Effluent } \\
\mathrm{Tl} \\
(\mathrm{ppb})\end{array}$ & $\begin{array}{c}\mathrm{MDL} \\
\mathrm{Tl} \\
(\mathrm{ppb})\end{array}$ & $\begin{array}{c}\text { Flow } \\
\text { Rate } \\
(\mathrm{mL} / \mathrm{Hr}) \\
\end{array}$ & $\begin{array}{l}\text { Res } \\
\text { Time } \\
\text { (min) }\end{array}$ & $\begin{array}{c}\text { Breakthru } \\
\text { Mn } \\
(\%) \\
\end{array}$ & $\begin{array}{c}\text { Breakthru } \\
\mathrm{Sb} \\
(\%) \\
\end{array}$ & $\begin{array}{c}\text { Breakthru } \\
\mathrm{Tl} \\
(\%) \\
\end{array}$ \\
\hline $\mathrm{H}-113$ & DIWash & & 20.8 & 0.70 & 1.0 & 0.40 & 0.5 & 0.3 & & & 4.4 & 1.3 & 1.0 \\
\hline $\mathrm{H}-123$ & $1^{\text {st }}$ Fraction & & 4.0 & 0.70 & 32.3 & 0.40 & 0.3 & 0.3 & 18.3 & 96.6 & 0.8 & 42.7 & 0.6 \\
\hline H- 133 & $2^{\text {nd }}$ Fraction & & 3.7 & 0.70 & 39.8 & 0.40 & 0.4 & 0.3 & 48.3 & 36.6 & 0.8 & 52.6 & 0.8 \\
\hline $\mathrm{H}-143$ & $3^{\text {rd }}$ Fraction & & 9.3 & 0.70 & 51.2 & 0.40 & 0.3 & 0.3 & 84.1 & 21.0 & 2.0 & 67.6 & 0.6 \\
\hline $\mathrm{H}-153$ & $4^{\text {th }}$ Fraction & & 18.2 & 0.70 & 49.4 & 0.40 & 0.3 & 0.3 & 120.1 & 14.7 & 3.9 & 65.2 & 0.6 \\
\hline H-163 & $5^{\text {th }}$ Fraction & & 28.5 & 0.70 & 45.0 & 0.40 & 0.6 & 0.3 & 151.8 & 11.6 & 6.0 & 59.4 & 1.2 \\
\hline $\mathrm{H}-173$ & $6^{\text {th }}$ Fraction & & 38.9 & 0.70 & 47.1 & 0.40 & 1.2 & 0.3 & $183.0^{\circ}$ & 9.7 & 8.2 & 62.2 & 2.5 \\
\hline $\mathrm{H}-183$ & $7^{\text {th }}$ Fraction & & 60.0 & 0.70 & 53.6 & 0.40 & 2.5 & 0.3 & 213.20 & 8.3 & 12.7 & 70.8 & 5.2 \\
\hline
\end{tabular}


Table A-5. Rocky Flats Barrier Materials Column Studies.

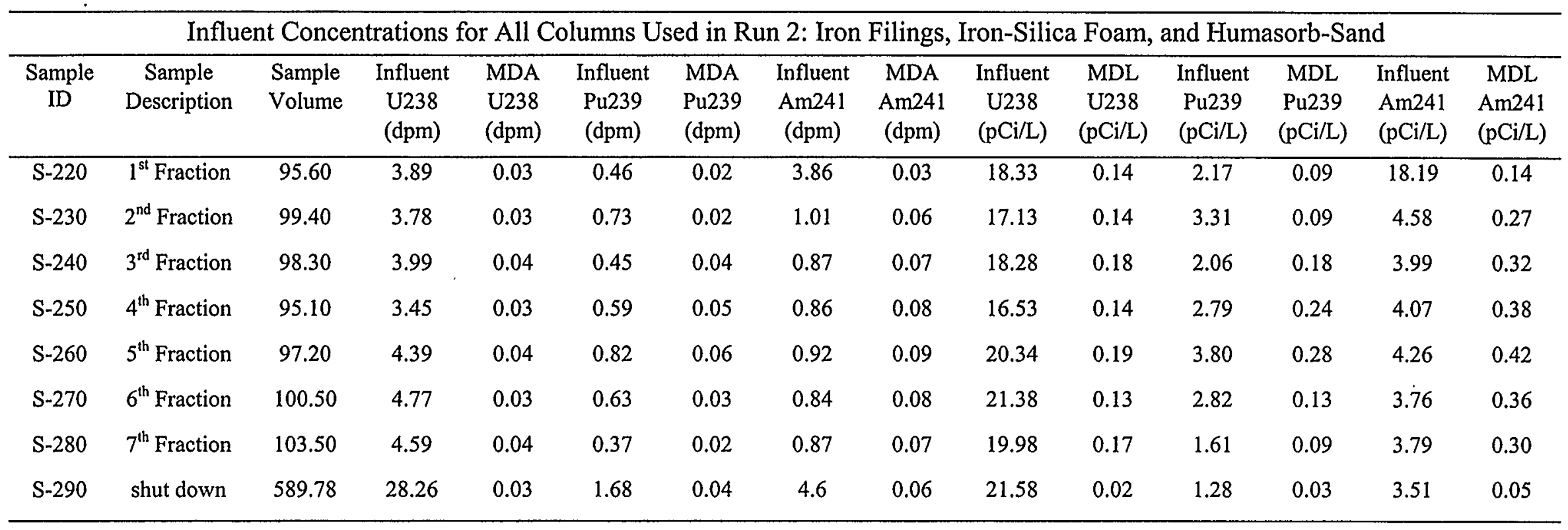


Table A-6. Rocky Flats Barrier Materials Column Studies.

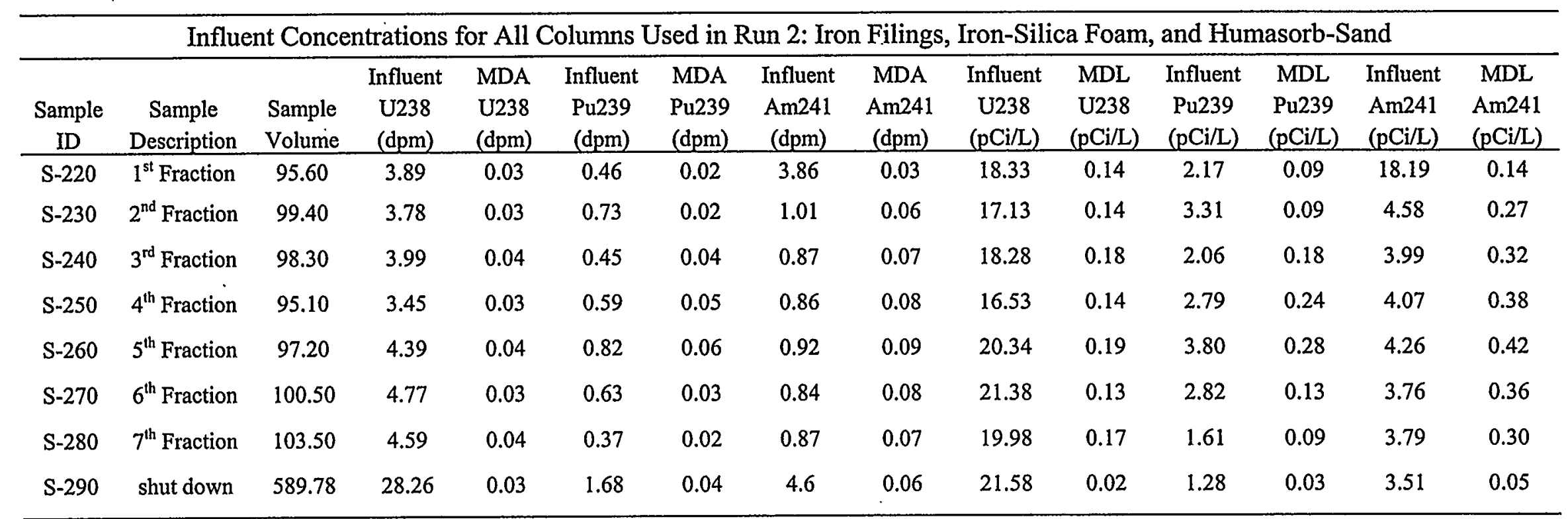


Table A-7. Rocky Flats Barrier Materials Column Studies.

\section{Effluents from the Iron-Silica Foam Column; Run 2}

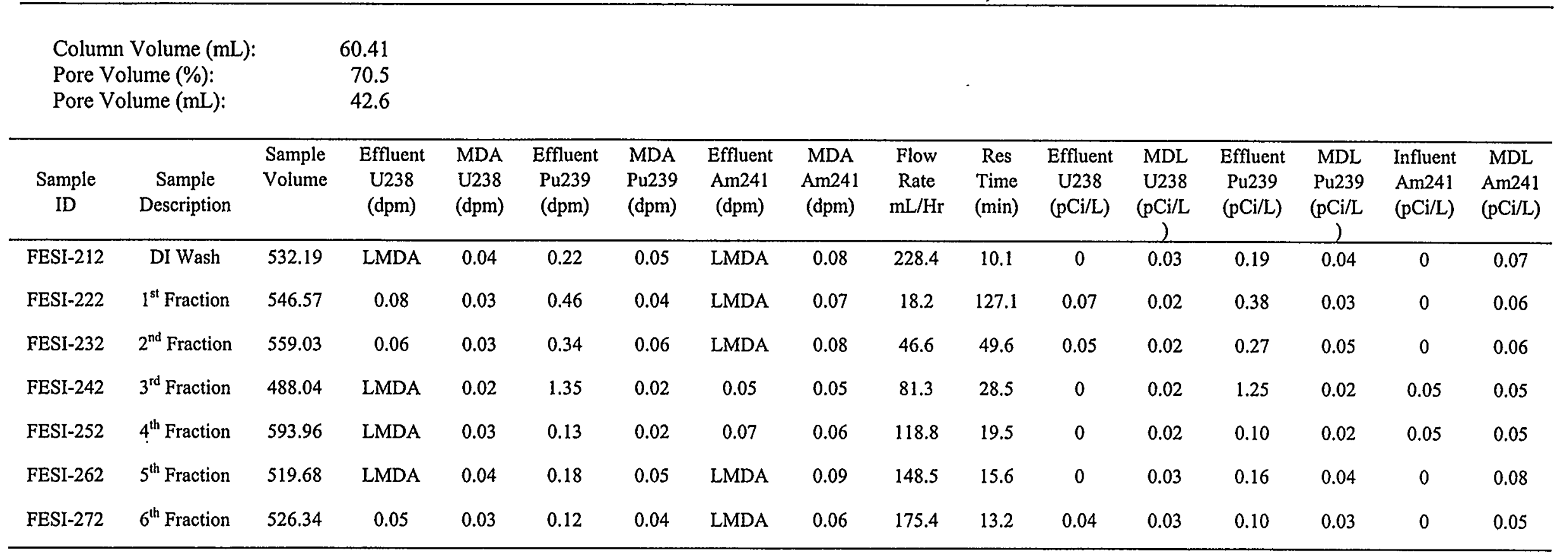

LMDA $=$ Lower than the MDA

Note: the $7^{\text {th }}$ fraction was discarded due to experimental error 
Table A-8. Rocky Flats Barrier Materials Column Studies.

\section{Effluents from Humasorb-Sand Column, Run 2}

\begin{tabular}{|c|c|c|c|c|c|c|c|c|c|c|c|c|c|c|c|c|}
\hline \multicolumn{3}{|c|}{$\begin{array}{l}\text { Column Volume (Ml): } \\
\text { Pore Volume (\%) } \\
\text { Pore Volume (Ml): }\end{array}$} & \multicolumn{14}{|l|}{$\begin{array}{l}58.25 \\
44.7 \\
26.0\end{array}$} \\
\hline $\mathrm{H}-233$ & $2^{\text {nd }}$ Fraction & 571.88 & 22.37 & 0.05 & 0.29 & 0.05 & LMDA & 0.08 & 47.7 & 32.8 & 17.62 & 0.04 & 0.23 & 0.04 & 0 & 0.06 \\
\hline $\mathrm{H}-243$ & $3^{\text {rd }}$ Fraction & 489.06 & 16.38 & 0.02 & 0.57 & 0.03 & LMDA & 0.08 & 81.5 & 19.2 & 15.09 & 0.02 & 0.53 & 0.03 & 0 & 0.07 \\
\hline $\mathrm{H}-253$ & $4^{\text {th }}$ Fraction & 598.08 & 23.12 & 0.02 & 0.15 & 0.01 & LMDA & 0.05 & 119.6 & 13.1 & 17.41 & 0.02 & 0.11 & 0.01 & 0 & 0.04 \\
\hline $\mathrm{H}-263$ & $5^{\text {th }}$ Fraction & 523.29 & 21.83 & 0.02 & -0.20 & 0.04 & LMDA & 0.10 & 149.5 & 10.4 & 18.79 & 0.02 & 0.17 & 0.03 & 0 & 0.09 \\
\hline
\end{tabular}

LMDA $=$ Lower than the MDA

Note: the $7^{\text {th }}$ fraction was discarded due to experimental error 


\section{APPENDIX B}

B -1 


\section{Iron Foam Pellets 1}

$\mathrm{L}(\mathrm{cm})$

A (cm2): $\frac{17.72}{36.50}$

Hc (cm): $\quad 36.50$

Ho (cm): $\quad 23.60$

Sample Mass (g): $\quad 180.92$

$\mathrm{Pb}\left(\mathrm{g} / \mathrm{cm}^{3}\right)$ :

2.04

Initial test:

\section{Outflow}

\begin{tabular}{|c|c|c|c|}
\hline Time (s) & Mass (g) & Tare (g) & Ks (cm/s) \\
\hline 30 & 180.98 & 59.84 & $8.85 \mathrm{E}-02$ \\
\hline 40 & 213.70 & 58.81 & $8.49 \mathrm{E}-02$ \\
\hline 40 & 213.65 & 58.70 & $8.49 \mathrm{E}-02$ \\
\hline 40 & 211.83 & 59.84 & $8.33 \mathrm{E}-02$ \\
\hline
\end{tabular}

Initial test $+12 \mathrm{hr}$ :

Outflow

\begin{tabular}{|c|c|c|c|}
\hline Time (s) & Mass (g) & Tare $(\mathrm{g})$ & $\mathbf{K s ~}(\mathbf{c m} / \mathbf{s})$ \\
\hline 30 & 171.91 & 59.84 & $8.19 \mathrm{E}-02$ \\
\hline 30 & 171.65 & 59.84 & $8.17 \mathrm{E}-02$ \\
\hline 30 & 171.95 & 58.81 & $8.27 \mathrm{E}-02$ \\
\hline
\end{tabular}

Iron Foam Pellets 2

\begin{tabular}{|c|c|}
\hline $\mathrm{L}(\mathrm{cm}):$ & 5.10 \\
\hline $\mathrm{A}(\mathrm{cm} 2)$ & 17.35 \\
\hline $\mathrm{Hc}(\mathrm{cm})$ & 36.50 \\
\hline Ho $(\mathrm{cm})$ : & 23.70 \\
\hline Mass (g): & 188.58 \\
\hline$\left(\mathrm{g} / \mathrm{cm}^{3}\right)$ & 2.13 \\
\hline
\end{tabular}

Initial test:

\section{Outflow}

\begin{tabular}{|c|c|c|c|}
\hline Time (s) & Mass (g) & Tare (g) & Ks (cm/s) \\
\hline 30 & 168.92 & 59.84 & $8.37 \mathrm{E}-02$ \\
\hline 30 & 167.67 & 59.84 & $8.27 \mathrm{E}-02$ \\
\hline 30 & 166.61 & 58.81 & $8.27 \mathrm{E}-02$ \\
\hline 30 & 162.74 & 58.70 & $7.98 \mathrm{E}-02$ \\
\hline
\end{tabular}

Initial test $+12 \mathrm{hr}$

Outflow

\begin{tabular}{|c|c|c|c|}
\hline Time (s) & Mass (g) & Tare (g) & Ks (cm/s) \\
\hline 30 & 155.70 & 59.88 & $7.35 \mathrm{E}-02$ \\
\hline 30 & 152.70 & 58.81 & $7.20 \mathrm{E}-02$ \\
\hline 30 & 152.31 & 58.70 & $7.18 \mathrm{E}-02$ \\
\hline
\end{tabular}

Iron Foam Pellets 3

$$
\begin{array}{rr}
\text { L (cm): } & 5.10 \\
\text { A (cm }): & 17.35 \\
\text { Hc }(\mathrm{cm}): & 36.50 \\
\text { Ho }(\mathrm{cm}): & 22.40 \\
\text { Sample Mass }(\mathrm{g}): & 199.89 \\
\mathrm{~Pb}\left(\mathrm{~g} / \mathrm{cm}^{3}\right): & 2.26
\end{array}
$$

Initial test

\section{Outflow}

\begin{tabular}{|c|c|c|c|}
\hline Time (s) & Mass (g) & Tare $(\mathrm{g})$ & $\mathbf{K s}(\mathrm{cm} / \mathbf{s})$ \\
\hline 30 & 139.66 & 58.70 & $5.64 \mathrm{E}-02$ \\
\hline 30 & 137.98 & 58.81 & $5.51 \mathrm{E}-02$ \\
\hline 30 & 135.15 & 59.84 & $5.25 \mathrm{E}-02$ \\
\hline 30 & 131.81 & 59.84 & $5.01 \mathrm{E}-02$ \\
\hline
\end{tabular}

\section{Iron Foam Pellets 4}

L $(\mathrm{cm}):$
A $(\mathrm{cm} 2): \frac{5.10}{\frac{17.35}{36.50}}$
Hc $(\mathrm{cm}):$
Ho $(\mathrm{cm}): \frac{22.40}{\frac{210.36}{2.38}}$
Mass $(\mathrm{g}):$

Initial test $+12 \mathrm{hr}$.

Outflow

\begin{tabular}{|c|c|c|c|}
\hline Time (s) & Mass (g) & Tare $(\mathrm{g})$ & $\mathrm{Ks}(\mathrm{cm} / \mathbf{s})$ \\
\hline 30 & 107.78 & 58.70 & $3.42 \mathrm{E}-02$ \\
\hline 30 & 116.12 & 58.81 & $3.99 \mathrm{E}-02$ \\
\hline 30 & 128.43 & 59.84 & $4.78 \mathrm{E}-02$ \\
\hline
\end{tabular}

Table B-1. Results of saturated hydraulic conductivity tests using Iron Foam Pellets media. 


\section{Connelly - GPM 1}

$\mathrm{L}(\mathrm{cm})$ :

A (cm2):

Hc (cm): 36.50

Ho (cm): 22.25

Sample Mass (g): 240.15

$\mathrm{Pb}\left(\mathrm{g} / \mathrm{cm}^{3}\right):$

271

Initial test:

Outflow

\begin{tabular}{|c|c|c|c|}
\hline Time (s) & Mass $(\mathrm{g})$ & Tare $(\mathrm{g})$ & $\mathrm{Ks}(\mathrm{cm} / \mathbf{s})$ \\
\hline 30 & 122.79 & 58.70 & $4.24 \mathrm{E}-02$ \\
\hline 30 & 111.57 & 58.81 & $3.49 \mathrm{E}-02$ \\
\hline 30 & 101.11 & 59.61 & $2.75 \mathrm{E}-02$ \\
\hline 30 & 91.39 & 59.88 & $2.08 \mathrm{E}-02$ \\
\hline
\end{tabular}

Initial test $+12 \mathrm{hr}$ :

Outflow

\begin{tabular}{|c|c|c|c|}
\hline Time (s) & Mass $(\mathrm{g})$ & Tare $(\mathrm{g})$ & Ks $(\mathrm{cm} / \mathrm{s})$ \\
\hline 30 & 82.97 & 58.70 & $1.61 \mathrm{E}-02$ \\
\hline 30 & 82.35 & 58.81 & $1.56 \mathrm{E}-02$ \\
\hline 30 & 81.08 & 59.61 & $1.42 \mathrm{E}-02$ \\
\hline 30 & 80.81 & 59.88 & $1.38 \mathrm{E}-02$ \\
\hline
\end{tabular}

\section{Connelly - GPM 2}

$\mathrm{L}(\mathrm{cm})$ :

A (cm2):

$\mathrm{Hc}(\mathrm{cm}):$

Ho $(\mathrm{cm})$ :

Sample Mass (g):

$\mathrm{Pb}\left(\mathrm{g} / \mathrm{cm}^{3}\right):$

Initial test:

Outflow

\begin{tabular}{|c|c|c|c|}
\hline Time (s) & Mass $(\mathrm{g})$ & Tare $(\mathrm{g})$ & Ks $(\mathbf{c m} / \mathbf{s})$ \\
\hline 30 & 159.67 & 58.70 & $6.98 \mathrm{E}-02$ \\
\hline 30 & 154.80 & 58.81 & $6.64 \mathrm{E}-02$ \\
\hline 30 & 141.13 & 59.61 & $5.64 \mathrm{E}-02$ \\
\hline 30 & 119.15 & 59.88 & $4.10 \mathrm{E}-02$ \\
\hline
\end{tabular}

Initial test $+12 \mathrm{hr}$ :

Outflow

\begin{tabular}{|c|c|c|c|}
\hline Time (s) & Mass (g) & Tare $(\mathbf{g})$ & Ks $(\mathbf{c m} / \mathbf{s})$ \\
\hline 30 & 102.13 & 58.70 & $3.00 \mathrm{E}-02$ \\
\hline 30 & 101.01 & 58.81 & $2.92 \mathrm{E}-02$ \\
\hline 30 & 97.44 & 59.61 & $2.62 \mathrm{E}-02$ \\
\hline 30 & 94.71 & 59.88 & $2.41 \mathrm{E}-02$ \\
\hline
\end{tabular}

\section{Connelly - GPM 3}

$\mathrm{L}(\mathrm{cm})$ :

A (cm2):

$\mathrm{Hc}(\mathrm{cm})$ :

Ho $(\mathrm{cm}):$

Sample Mass (g):

$\mathrm{Pb}\left(\mathrm{g} / \mathrm{cm}^{3}\right)$

$\begin{array}{r}5.10 \\ \hline 17.35 \\ \hline 36.50 \\ \hline 22.45 \\ \hline 257.19 \\ \hline 2.91 \\ \hline\end{array}$

Initial test:

Outflow

\begin{tabular}{|c|c|c|c|}
\hline Time (s) & Mass $(\mathrm{g})$ & Tare $(\mathrm{g})$ & Ks $(\mathrm{cm} / \mathbf{s})$ \\
\hline 30 & 81.13 & 58.70 & $1.57 \mathrm{E}-02$ \\
\hline 30 & 96.53 & 58.81 & $2.64 \mathrm{E}-02$ \\
\hline 30 & 74.71 & 59.61 & $1.06 \mathrm{E}-02$ \\
\hline 30 & 71.52 & 59.88 & $8.14 \mathrm{E}-03$ \\
\hline
\end{tabular}

Initial test $+12 \mathrm{hr}$ :

Outflow

\begin{tabular}{|c|c|c|c|}
\hline Time (s) & Mass $(\mathrm{g})$ & Tare $(\mathrm{g})$ & $\mathbf{K s}(\mathrm{cm} / \mathbf{s})$ \\
\hline 30 & 59.44 & 58.70 & $5.17 \mathrm{E}-04$ \\
\hline 30 & 59.48 & 58.81 & $4.68 \mathrm{E}-04$ \\
\hline 30 & 60.36 & 59.61 & $5.24 \mathrm{E}-04$ \\
\hline 30 & 60.53 & 59.88 & $4.54 \mathrm{E}-04$ \\
\hline
\end{tabular}

Table B-2. Results of saturated hydraulic conductivity tests using Iron Filings media. 


\section{Humasorb-CS 1}

L (cm):
A (cm2): $\frac{17.00}{\frac{17.72}{36.50}}$
Hc $(\mathrm{cm}): \frac{23.00}{\frac{79.21}{0.89}}$
Ho $(\mathrm{cm}): \frac{1}{\text { Mass }(\mathrm{g}):}$

Initial test:

\section{Outflow}

\begin{tabular}{|c|c|c|c|}
\hline Time (s) & Mass (g) & Tare (g) & Ks (cm/s) \\
\hline 30 & 168.51 & 58.70 & $7.67 \mathrm{E}-02$ \\
\hline 30 & 164.26 & 58.81 & $7.36 \mathrm{E}-02$ \\
\hline 30 & 161.64 & 59.61 & $7.12 \mathrm{E}-02$ \\
\hline 30 & 159.57 & 59.88 & $6.96 \mathrm{E}-02$ \\
\hline
\end{tabular}

Initial test $+72 \mathrm{hr}$.

Outflow

\begin{tabular}{|c|c|c|c|}
\hline Time (s) & Mass (g) & Tare (g) & Ks (cm/s) \\
\hline 30 & 76.68 & 58.70 & $1.26 \mathrm{E}-02$ \\
\hline 30 & 79.04 & 58.81 & $1.41 \mathrm{E}-02$ \\
\hline 30 & 79.06 & 59.61 & $1.36 \mathrm{E}-02$ \\
\hline 30 & 79.58 & 59.88 & $1.38 \mathrm{E}-02$ \\
\hline
\end{tabular}

\section{Humasorb-CS 2}

$\mathrm{L}(\mathrm{cm})$ : A (cm2): $\mathrm{Hc}(\mathrm{cm})$ Ho (cm):

Sample Mass (g): $\mathrm{Pb}\left(\mathrm{g} / \mathrm{cm}^{3}\right)$ : 5.10

$\begin{array}{r}17.35 \\ \hline 36.50 \\ \hline 24.70 \\ \hline 92.86 \\ \hline 1.05 \\ \hline\end{array}$

Initial test:

Outflow

\begin{tabular}{|c|c|c|c|}
\hline Time (s) & Mass (g) & Tare (g) & Ks (cm/s) \\
\hline 30 & 126.87 & 58.70 & $5.67 \mathrm{E}-02$ \\
\hline 30 & 119.34 & 58.81 & $5.04 \mathrm{E}-02$ \\
\hline 30 & 116.36 & 59.61 & $4.72 \mathrm{E}-02$ \\
\hline 30 & 121.67 & 59.88 & $5.14 \mathrm{E}-02$ \\
\hline
\end{tabular}

Initial test $+72 \mathrm{hr} .:$

Outflow

\begin{tabular}{|c|c|c|c|}
\hline Time (s) & Mass (g) & Tare (g) & Ks (cm/s) \\
\hline 30 & 60.29 & 58.70 & $1.32 \mathrm{E}-03$ \\
\hline 30 & 60.50 & 58.81 & $1.41 \mathrm{E}-03$ \\
\hline 30 & 61.31 & 59.61 & $1.41 \mathrm{E}-03$ \\
\hline 30 & 61.51 & 59.88 & $1.36 \mathrm{E}-03$ \\
\hline
\end{tabular}

\section{Humasorb-CS 3}

$\mathrm{L}(\mathrm{cm})$ :

A (cm2):

Hc (cm): $\quad 36.50$

Ho (cm): $\quad 22.70$

Sample Mass (g): $\quad 92.54$

$\mathrm{Pb}\left(\mathrm{g} / \mathrm{cm}^{3}\right)$ : 1.05

Initial test:

Outflow

\begin{tabular}{|c|c|c|c|}
\hline Time (s) & Mass (g) & Tare (g) & Ks (cm/s) \\
\hline 30 & 108.38 & 58.70 & $3.54 \mathrm{E}-02$ \\
\hline 30 & 104.75 & 58.81 & $3.27 \mathrm{E}-02$ \\
\hline 30 & 100.03 & 59.61 & $2.88 \mathrm{E}-02$ \\
\hline 30 & 102.59 & 59.88 & $3.04 \mathrm{E}-03$ \\
\hline
\end{tabular}

Initial test $+72 \mathrm{hr}$ :

Outflow

\begin{tabular}{|c|c|c|c|}
\hline Time (s) & Mass (g) & Tare (g) & Ks (cm/s) \\
\hline 30 & 60.78 & 58.70 & $1.48 \mathrm{E}-03$ \\
\hline 30 & 61.07 & 58.81 & $1.61 \mathrm{E}-03$ \\
\hline 30 & 61.85 & 59.61 & $1.59 \mathrm{E}-03$ \\
\hline 30 & 62.22 & 59.88 & $1.67 \mathrm{E}-03$ \\
\hline
\end{tabular}

Table B-3. Results of saturated hydraulic conductivity tests using Humasorb-CS media.

$$
\text { B }-4
$$




\section{APPENDIX C}

C -1 
Table C-1. The Concentrations of Volatile Organic Species Present at Various Samplings of the Column Influents and Effluents.

Column Characteristics

Column Identification

Length of Column (inch)

Mass of Iron Filings (g)

Pore Volume $(\mathrm{mL})$

Influent

\begin{tabular}{rrrrrr} 
& & & & \\
ent & FE3 & FE6 & FE12 & FE24 & FE36 \\
\hline 0 & 3.00 & 6.00 & 12.00 & 24.00 & 36.00 \\
0 & 905 & 1867 & 3687 & 7283 & 10951 \\
0 & 203 & 387 & 774 & 1545 & 2342
\end{tabular}

Day of 7/16/97 (initial plug of effluent)

SMO Sample Number

3823

Benzene

Chloromethane

Day of $7 / 18 / 97$

SMO Sample Number

Av Daily Flow Rate $(\mathrm{mL} / \mathrm{hr})$

Residence Time (hr)

Carbon Tetrachloride

Chloroform

Cis-1,2-Dichloroethene

Methylene Chloride

Metrachloroethane

1,1,1-Trichloroethane

Trichloroethene

Day of $7 / 22 / 98$

SMO Sample Number Average Influent $33765 \quad 33766 \quad 33767 \quad 33768 \quad 33764$

Av Daily Flow Rate (mL/hr)

Residence Time (hr)

Carbon Tetrachloride

Chloroform

Cis-1,2-Dichloroethene

Methylene Chloride

Tetrachloroethane

1,1,1-Trichloroethane

Trichloroethene

Average Influent

$\begin{array}{rrrrr}33825 & 33826 & 33827 & 33828 & 33824\end{array}$

$\begin{array}{rrrrrr}\text { NA } & 122 & 122 & 121 & 124 & 128 \\ 0 & 1.66 & 3.16 & 6.39 & 12.46 & 18.24 \\ 34 & 1 & 1 & 1 & 1 & 1 \\ 9 & 4.4 & 1 & 1 & 1 & 1\end{array}$

Day of $7 / 23 / 99$

SMO Sample Number

Av Daily Flow Rate $(\mathrm{mL} / \mathrm{hr})$

Residence Time (hr)

Carbon Tetrachloride

Chloroform

Cis-1,2-Dichloroethene

Methylene Chlorid

Tetrachloroethane

1,1,1-Trichloroethane

Trichloroethene

\begin{tabular}{rrrrrr} 
NA & 114 & 120 & 116 & 119 & 134 \\
0 & 1.78 & 3.22 & 6.68 & 12.94 & 17.50 \\
34 & 1 & 1 & 1 & 1 & 1 \\
9 & 1.5 & 1 & 1 & 1 & 1 \\
9 & 1 & 1 & 1 & 1 & 1 \\
1 & 1.4 & 1.3 & 1 & 1.1 & 1.1 \\
9 & 1 & 1 & 1 & 1 & 1 \\
2 & 1 & 1 & 1 & 1 & 1 \\
14 & 1 & 1 & 1 & 1 & 1 \\
\hline
\end{tabular}

\begin{tabular}{rrrrrr} 
NA & 33771 & 33772 & 33773 & 33774 & 33770 \\
0 & 113 & 121 & 116 & 121 & 130 \\
34 & 1.80 & 3.21 & 6.68 & 12.78 & 18.06 \\
9 & 1 & 1 & 1 & 1 & 1 \\
9 & 1 & 1 & 1 & 1 & 1 \\
1 & 1 & 1 & 1 & 1 & 1 \\
9 & 1.6 & 1.5 & 1 & 1 & 1 \\
2 & 1 & 1 & 1 & 1 & 1 \\
14 & 1 & 1 & 1 & 1 & 1 \\
\hline
\end{tabular}




\section{Day of $7 / 24 / 100$}

SMO Sample Number

Av Daily Flow Rate (mL/hr)

Average Influent

$\begin{array}{rr}33802 & 33803 \\ 109 & 116\end{array}$

\begin{tabular}{rrrrr}
33802 & 33803 & 33804 & 33805 & 33801 \\
109 & 116 & 111 & 115 & 121 \\
1.87 & 3.34 & 6.95 & 13.45 & 19.35 \\
1 & 1 & 1 & 1 & $I$ \\
1 & 1 & 1 & 1 & 1 \\
1 & 1 & 1 & 1 & 1 \\
1.2 & 1.2 & 1 & 1 & 1 \\
1 & 1 & 1 & 1 & 1 \\
1 & 1 & 1 & 1 & 1 \\
$l$ & 1 & $l$ & 1 & 1 \\
\hline
\end{tabular}

Carbon Tetrachloride

Chloroform

Cis-1,2-Dichloroethene

Methylene Chloride

Tetrachloroethane

1,1,1-Trichloroethane

$\begin{array}{rr}109 & 116 \\ 1.87 & 3.34\end{array}$

$\begin{array}{rr}0 & 1.87 \\ 34 & \end{array}$

phase volatile orgatics are detection limits and indicate that the concentration of that species for that sample is below the detection limit. EPA method 8260 was us 
Table C-2. The Concentrations of Various Heavy Metal Species Present at Samplings of the Column Influents and Effluents.

\begin{tabular}{lcccrrr} 
Column Characteristics & & & & & & \\
Column Identification & Influent & FE3 & FE6 & FE12 & FE24 & FE36 \\
\hline Length of Column (inch) & 0 & 3.00 & 6.00 & 12.00 & 24.00 & 36.00 \\
Mass of Iron Filings $(\mathrm{g})$ & 0 & 905 & 1867 & 3687 & 7283 & 10951 \\
Pore Volume $(\mathrm{mL})$ & 0 & 203 & 387 & 774 & 1545 & 2342 \\
\hline
\end{tabular}

\begin{tabular}{lr} 
Day of $7 / 16 / 97$ (initial plug of effluent) & 33788 \\
SMO Sample Number & 3 \\
\hline Antimony $(\mp g / L)$ & 310000 \\
Iron $(\mp g / L)$ & 34300 \\
Manganese $(\mp g / L)$ & 1
\end{tabular}

\begin{tabular}{|c|c|c|c|c|c|c|}
\hline $\begin{array}{l}\text { Day of } 7 / 18 / 97 \\
\text { SMO Sample Number }\end{array}$ & Average Influent & 33790 & 33791 & 33792 & 33793 & 33789 \\
\hline Av Daily Flow Rate (mL/hr) & NA & 122 & 122 & 121 & 124 & 128 \\
\hline Residence Time (hr) & 0 & 1.66 & 3.16 & 6.39 & 12.46 & 18.24 \\
\hline Antimony $(\mp g / L)$ & 3 & 3 & 3 & 3 & 3 & 3 \\
\hline Iron $(\mp g / L)$ & 30 & 1280 & 2060 & 4880 & 1210 & 280 \\
\hline Manganese $(\mp g / L)$ & 32 & 194 & 255 & 481 & 786 & 162 \\
\hline Thallium $(\mp g / L)$ & 1 & 1 & 1 & 1 & 1 & 1 \\
\hline
\end{tabular}

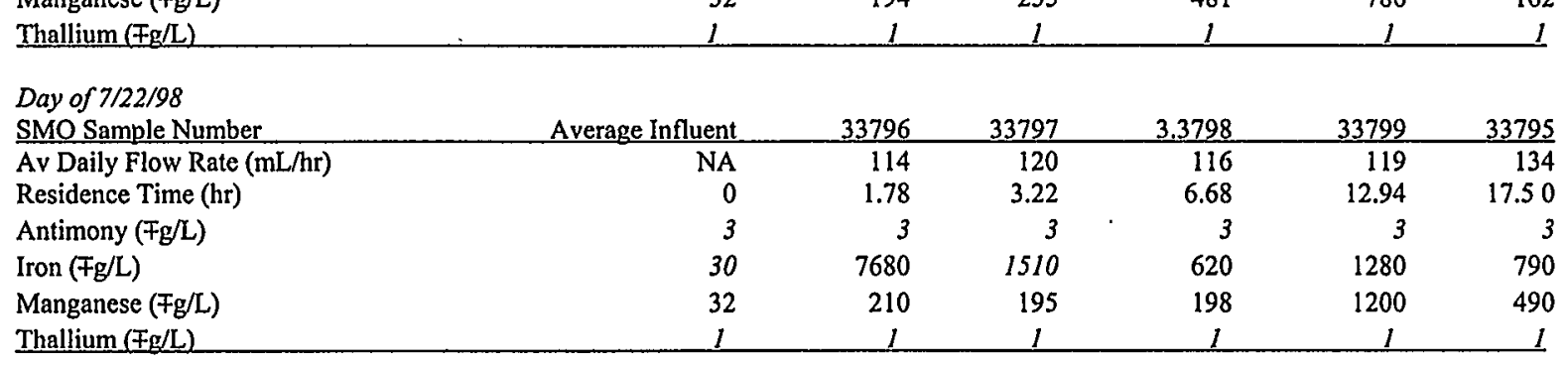

\begin{tabular}{|c|c|c|c|c|c|c|}
\hline Day of 7/23/99 & & & & & & \\
\hline SMO Sample Number & Average Influent & 33777 & 33778 & 33779 & 3.3780 & 33776 \\
\hline Av Daily Flow Rate (mL/hr) & NA & 113 & 121 & 116 & 121 & 130 \\
\hline Residence Time (hr) & 0 & 1.80 & 3.21 & 6.68 & 12.78 & 18.06 \\
\hline Antimony $(\mp g / L)$ & 3 & 3 & 3 & 3 & 3 & 3 \\
\hline $\operatorname{Iron}(\mp g / L)$ & 30 & 1100 & 430 & 140 & 90 & 370 \\
\hline Manganese $(\mp g / L)$ & 32 & 87 & 125 & 207 & 494 & 391 \\
\hline Thallium $(\mp g / L)$ & 1 & 1 & 1 & $I$ & 1 & 1 \\
\hline
\end{tabular}

\section{Day of $7 / 24 / 100$}

\begin{tabular}{lrrrrrr} 
SMO Sample Number & Average Influent & 33.808 & 33.809 & 33810 & 33811 & 33807 \\
\hline Av Daily Flow Rate $(\mathrm{mL} / \mathrm{hr})$ & NA & 109 & 116 & 111 & 115 & 121
\end{tabular}

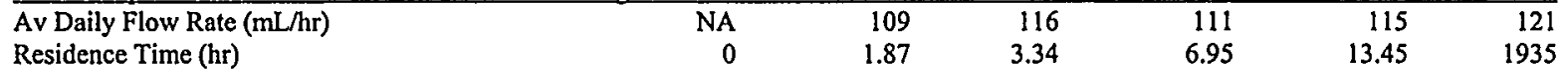


Antimony $(\mp g / L)$

Iron $(F g / L)$

$\begin{array}{llllll}3 & 3 & 3 & 3 & 3 & 3\end{array}$

Manganese $(\mp g / \mathrm{L})$

\begin{tabular}{|c|c|}
\hline 2110 & 630 \\
\hline 128 & 146 \\
\hline
\end{tabular}

$32 \quad 128$

146

1

352

Note: Numbers in italics are detection limits and indicate that the concentration of that species for that sample is below the detection limit. The concentrations of antimony and thallium were determined, but these elements were never detected in any sample. 
Table C-3. The Concentrations of Various Radioactive Species Present at Samplings of the Column Influents and Effluents.

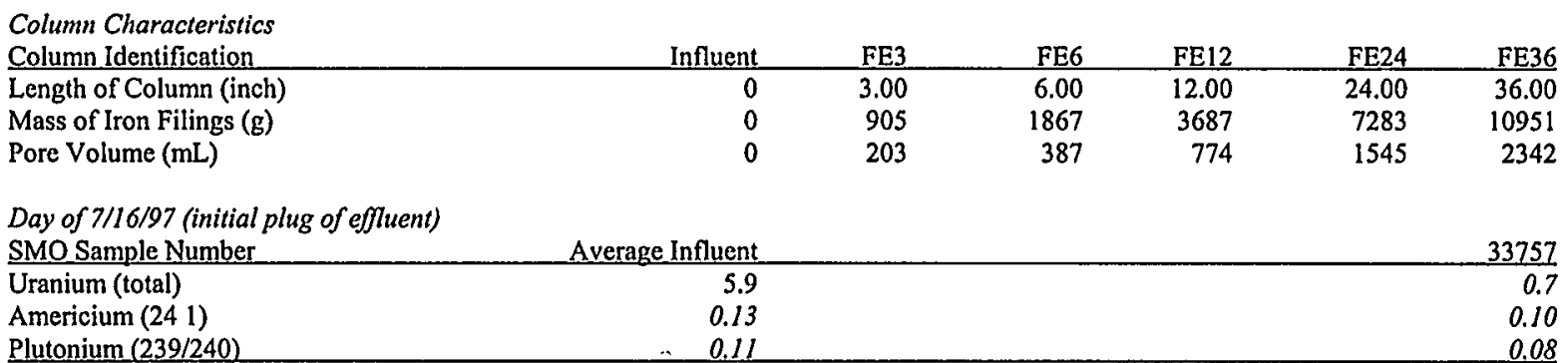

Day of $7 / / 8 / 97$

\begin{tabular}{lrrrrrr} 
& Average Influent & 33759 & 33760 & 33761 & 33762 & 33758 \\
SMO Sample Number & NA & 122 & 122 & 121 & 124 & 128 \\
\hline Av Daily Flow Rate (mL/hr) & 0 & 1.66 & 3.16 & 6.39 & 12.46 & 18.24 \\
Residence Time (hr) & 5.9 & 0.7 & 0.7 & 0.7 & 0.7 & 0.7 \\
Uranium (total) & 0.13 & 0.09 & 0.08 & 0.07 & 0.07 & 0.14 \\
Americium (241) & 0.11 & 0.05 & 0.05 & 0.06 & 0.08 & 0.04 \\
Plutonium (239/240) & & & & &
\end{tabular}

\section{Day of $7 / 22 / 98$}

\begin{tabular}{lrrrrrr} 
SMO Sample Number & Average Influent & 33831 & 33832 & 3,3833 & 33.834 & 33830 \\
\hline Av Daily Flow Rate $(\mathrm{mL} / \mathrm{hr})$ & $\mathrm{NA}$ & 114 & 120 & 116 & 119 & 134 \\
Residence Time (hr) & 0 & 1.78 & 3.22 & 6.68 & $12 @ 94$ & 17.50 \\
Uranium (total) & 5.9 & 0.7 & 2.2 & $0 @ 7$ & 0.7 & 0.7 \\
Americium (241) & 0.13 & 0.10 & 0.15 & 0.13 & 0.13 & 0.08 \\
Plutonium (239/240) & 0.11 & 0.06 & 0.09 & 0.09 & 0.05 & 0.04 \\
\hline
\end{tabular}

\begin{tabular}{|c|c|c|c|c|c|c|}
\hline Plutonium $(239 / 240)$ & 0.11 & 0.06 & 0.09 & 0.09 & 0.05 & 0.04 \\
\hline \multicolumn{7}{|l|}{ Day of $7 / 24 / 100$} \\
\hline SMO Sample Number & Average Influent & 33814 & 3381.5 & 33.816 & 33817 & 33813 \\
\hline Av Daily Flow Rate (mL/hr) & NA & 109 & 116 & 111 & 115 & 121 \\
\hline Residence Time (hr) & 0 & 1.87 & 3.34 & 6.95 & 13.45 & 19.35 \\
\hline Uranium (total) & 5.9 & 3.8 & 0.7 & 0.7 & 0.7 & 0.7 \\
\hline Americium (241) & 0.13 & 0.14 & 0.09 & 0.11 & 0.12 & 0.09 \\
\hline Plutonium $(239 / 240)$ & 0.11 & 0.07 & 0.05 & 0.05 & 0.06 & 0.04 \\
\hline
\end{tabular}

Note: Numbers in italics are detection limits and indicate that the concentration of that species for that sample is below the detection limit. 


\section{DISTRIBUTION}

2 Idaho National Engineering \&

Environmental Lab

Attn: Jay T. Brown

BBWI

P.O. Box 1625

Idaho Falls, ID 83415-3710

1 Los Alamos National Laboratory

Attn: Bruce Erdal

EM-TD

MS J591

Los Alamos, NM 87545

1 National Research Council

Attn: Robert Andrews, Ph.D.

National Academy of Science

Board of Radioactive Waste Mgmt.

2001 Wisconsin Ave., N.W.

Washington, DC 20007

1 New Mexico Environment Department

Attn: J. Espinosa

1190 St. Francis Drive

Santa Fe, NM 87503

1 New Mexico State Library

325 Don Gaspar

Santa Fe, NM 87503

1 New Mexico Tech

Attn: Martin Speere Memorial Library

Campus Street

Socorro, NM 87810

I Oak Ridge National Laboratory

Attn: Tom Early

P.O. Box 2008

Oak Ridge, TN 37831

1 Thomas Branigan Library

Attn: D. Dresp

$106 \mathrm{~W}$. Hadley St.

Las Cruces, NM 88003

1 U.S. Department of Energy

Attn: Paul Beam

EM-40

Cloverleaf Building

19901 Germantown Rd.

Germantown, MD 20874

1 U.S. Department of Energy

Attn: Skip Chamberlain
EM-53

Cloverleaf Building

19901 Germantown Rd.

Germantown, MD 20874

1 U.S. Department of Energy

Attn: Gillian Eaton

Rocky Flats

Tech Site, Bldg. T124A

P.O. Box 928

Golden, CO 80402

1 U.S. Department of Energy

Attn: John Geiger

Savannah River Operations Office

P.O. Box A

Aiken, SC 29802

1 U.S. Department of Energy

Attn: Marvin Gross

Fernald Field Office

P.O. Box 538704

Cincinnati, $\mathrm{OH} 45253$

1 U.S. Department of Energy

Attn: Thomas Hicks

Savannah River Operations Office

Bldg. 703-46A

P.O. Box A

Aiken, SC 29802

1 U.S. Department of Energy

Attn: Gary Huffman

Rocky Flats Office

Highway $93^{\text {rd }} \&$ Cactus St.

Golden, CO 80402

1 U.S. Department of Energy

Attn: Donald Williams

Office of Site Closure

EM-32/GTN (clov 2170)

19901 Germantown Rd

Germantown, MD 20874

1 U.S. Department of Energy

Attn: Scott McMullin

Savannah River Operations Office

P.O. Box A

Aiken, SC 29802

1 U.S. Department of Energy

Attn: Elizabeth Phillips

Oak Ridge Operations Office

P.O. Box 2001

Oak Ridge, TN 37830

Dist-1 
1 U.S. Department of Energy

Attn: Shannon Saget

Richland Operations Office

P.O. Box 550, K8-50

Richland, WA 99352

1 U.S. Department of Energy

Attn: Pam Saxman

Albuquerque Operations Office

P.O. Box 5400

Albuquerque, NM 87185

1 U.S. Department of Energy

Attn: George Schneider

Idaho Operations Office

785 DOE Place

Idaho Falls, ID 83402

1 U.S. Department of Energy

Attn: Mel Shupe

Federal Energy Technology Center

Industrial Park

P.O. Box 3462

Butte, MT 59702

1 U.S. Department of Energy

Attn: Jef Walker

EM-53

Cloverleaf Bldg.

19901 Germantown Rd.

Germantown, MD 20874

1 U.S. Department of Energy

Attn: Phillip Washer

Savannah River Operations Office

Bldg. 773-A

P.O. Box 616

Aiken, SC 29803

1 U.S. Department of Energy

Attn: James Wright

Savannah River Operations Office

Bldg. 703-46A

P.O. Box A

Aiken, SC 29803

1 U.S. Department of Energy

Attn: Linton W. Yarbrough, $\mathrm{PhD}$

P.O. Box 5400

H Street and Pennsylvania

KAFB

Albuquerque, NM 87185

1 U.S. Department of Energy

Attn: Paul Zielinski
EM-443

Cloverleaf Bldg. 19901 Germantown Rd.

Germantown, MD 20874

1 U. S. Environmental Protection Agency Attn: Ken Skahn (5202G) 401 M Street S.W.

Washington, D.C. 20460

1 MS0701 P. B. Davies, 6100

1 MS0719 W. B. Cox , 6131

10 MS0719 B. P. Dwyer, 6131

1 MS0719 J. P. Chavez, 6131

1 MS0719 D.A. Padilla, 6131

1 MS0724 R. J. Eagan, 6000

1 MS1147 F. B. Nimick, 6133

1 MS0612 Review \& Approval Desk, 9612 for DOE/OSTI

2 MS0899 Technical Library, 9616

1 MS9018 Central Technical Files, 8945-1 